\title{
Response of Vegetation in Open and Partially Wooded Fens to Prescribed Burning at Seney National Wildlife Refuge
}

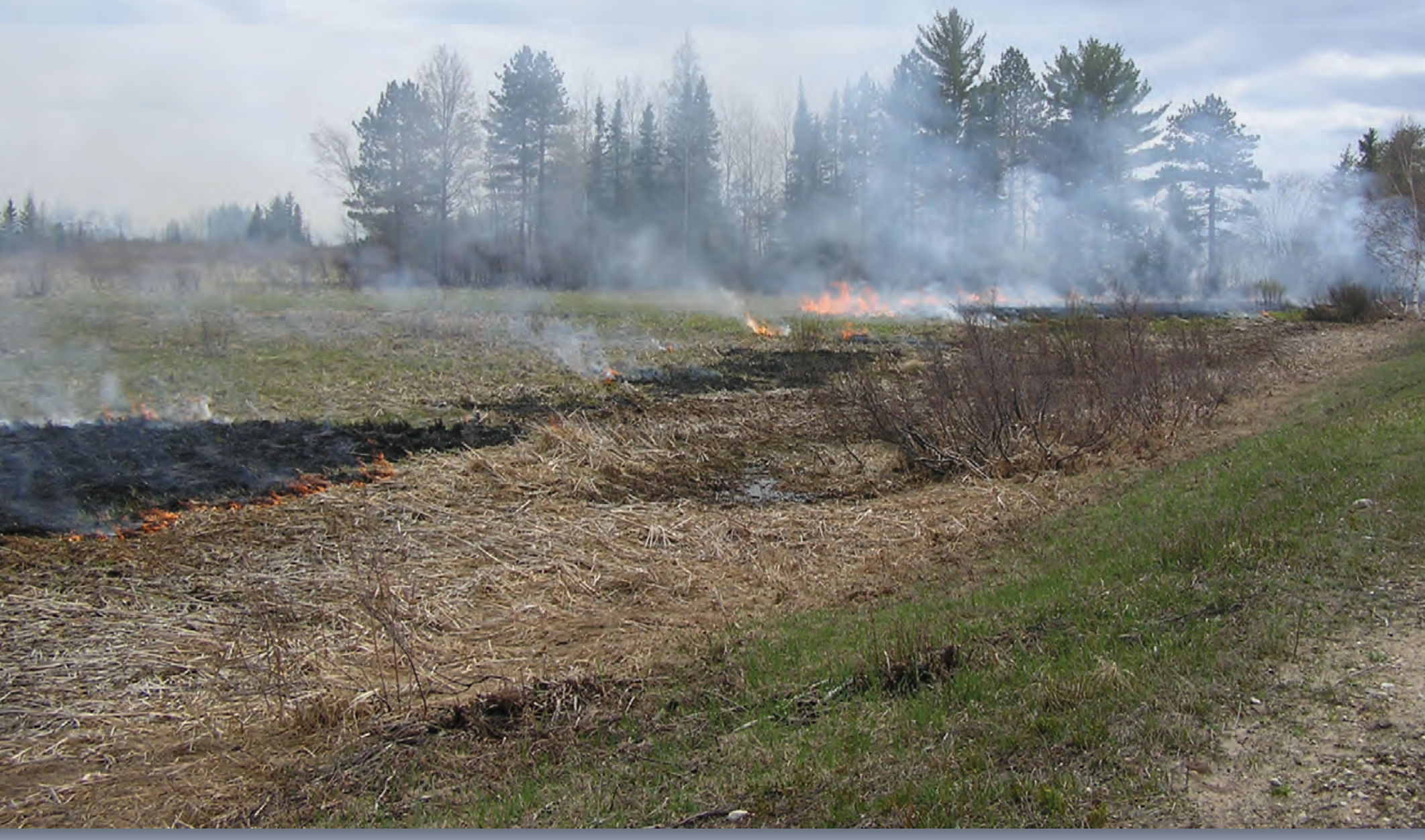

Scientific Investigations Report 2018-5168 
Cover. Photographs of prescribed burns at Seney National Wildlife Refuge.

Photographs by J.E. Austin, U.S. Geological Survey 


\section{Response of Vegetation in Open and Partially Wooded Fens to Prescribed Burning at Seney National Wildlife Refuge}

By Jane E. Austin and Wesley E. Newton

Scientific Investigations Report 2018-5168 


\title{
U.S. Department of the Interior \\ DAVID BERNHARDT, Acting Secretary
}

\author{
U.S. Geological Survey \\ James F. Reilly II, Director
}

U.S. Geological Survey, Reston, Virginia: 2019

For more information on the USGS - the Federal source for science about the Earth, its natural and living resources, natural hazards, and the environment-visit https://www.usgs.gov or call 1-888-ASK-USGS.

For an overview of USGS information products, including maps, imagery, and publications,

visit https://store.usgs.gov.

Any use of trade, firm, or product names is for descriptive purposes only and does not imply endorsement by the U.S. Government.

Although this information product, for the most part, is in the public domain, it also may contain copyrighted materials as noted in the text. Permission to reproduce copyrighted items must be secured from the copyright owner.

Suggested citation:

Austin, J.E., and Newton, W.E., 2019, Response of vegetation in open and partially wooded fens to prescribed burning at Seney National Wildlife Refuge: U.S. Geological Survey Scientific Investigations Report 2018-5168, 62 p., https://doi.org/10.3133/sir20185168.

ISSN 2328-0328 (online) 


\section{Acknowledgments}

Seney National Wildlife Refuge provided logistical support, historical information, and spatial data. We are particularly appreciative of $\mathrm{D}$. Olson, refuge biologist, and G. Lindsay, fire management officer, at Seney National Wildlife Refuge for their support and insightful discussions about wetland and fire ecology and management.

Funding was provided by U.S. Geological Survey's Northern Prairie Wildlife Research Center. This study was not possible without field assistance provided by botanists $S$. Danneman, A. Sabai, and S. Swanson, and other field assistance from N. Carle, J. Edwards, A. Given, C. Hanson, K. Marinoff, and B. Pauly. We thank D. Olson, G. Lindsay, K. Kowalski, and B. Middleton for their comments on earlier drafts. 



\section{Contents}

Acknowledgments ……...................................................................................................................

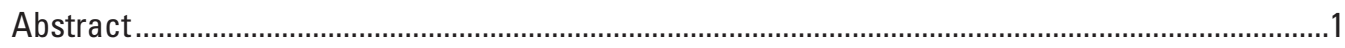

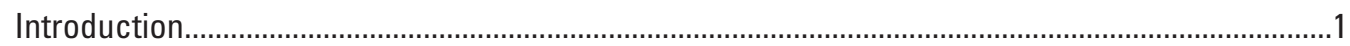

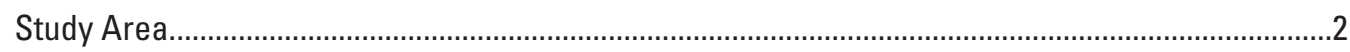

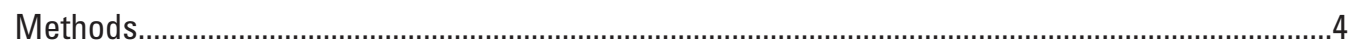

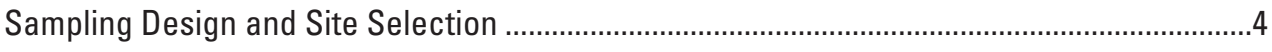

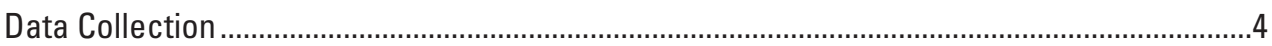

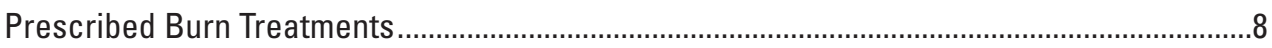

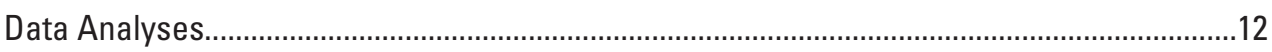

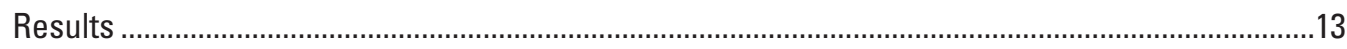

Environmental and Habitat Variables ................................................................................

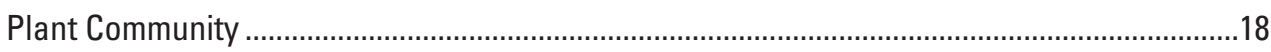

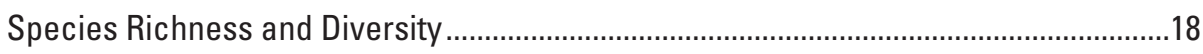

Percent Cover by Taxa—Year and Treatment Effects ......................................................18

Changes in Plant Community Indicated by Ordinations .......................................................29

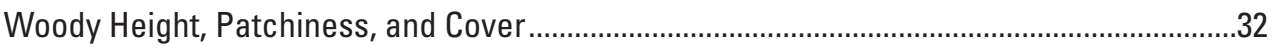

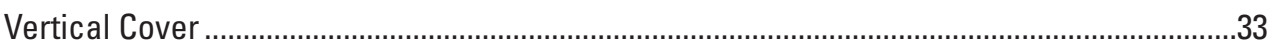

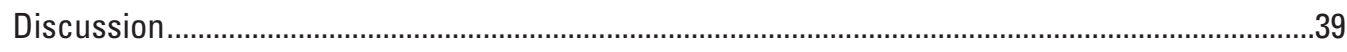

Changes in Plant Community ............................................................................................ 40

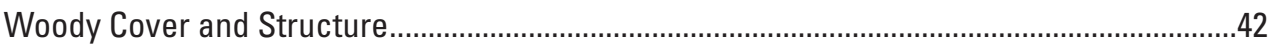

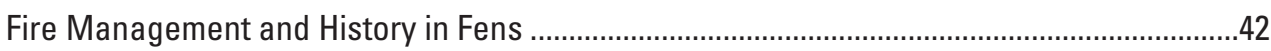

Rethinking Fire Management for Controlling Woody Encroachment in Fens.................................43

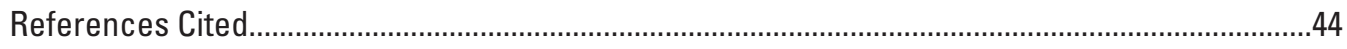

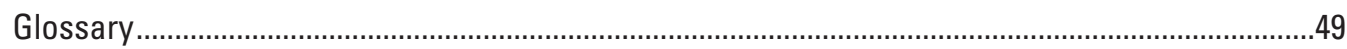

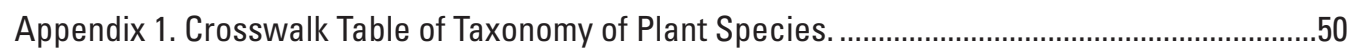

References Cited................................................................................................................53

Appendix 2. Fire Conditions During Prescribed Burns at Marsh Creek, July 2007

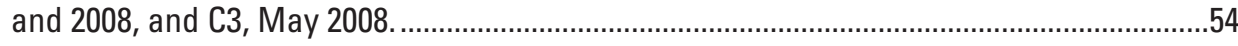

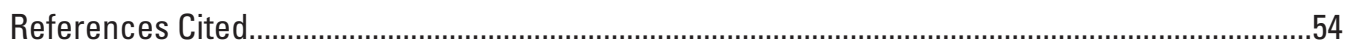

Appendix 3. Frequency of Occurrence of Plant Taxa by Block in C3 and Marsh Creek, Seney National Wildlife Refuge, 2006-10...................................................................55

Appendix 4. Frequency of Occurrence and Percent of Points (Summed Across Sampling Years) of Plant Taxa by Block in Marsh Creek, Seney National Wildlife Refuge, Michigan, 2006-10.

\section{Figures}

1. Map showing location of C3 and Marsh Creek study areas in Seney National Wildlife Refuge, in the upper peninsula of Michigan .

2. Map showing location of study blocks at the C3 study area relative to cover types in Seney National Wildlife Refuge, Michigan .........................................................5

3. Map showing location of study blocks at the Marsh Creek study area relative to cover types in Seney National Wildlife Refuge, Michigan. 
4. Diagram showing layout of transects and sampling points, spaced 25 meters apart, and associated identifying numbers, within each experimental block.

5. Photographs of conditions after the prescribed burn on the C3 study area, May 2008

6. Photographs of conditions after the prescribed burn on the MC-2 block of the Marsh Creek study area, July 2007.

7. Photographs of conditions after prescribed burn on the Marsh Creek study area, July 2008

8. Graphs showing summer water depths in control and burn blocks in C3 and

Marsh Creek blocks, 2006-10, at Seney National Wildlife Refuge, Michigan.

9. Graphs showing litter depths in control and burn blocks in C3 and Marsh Creek blocks, 2006-10, at Seney National Wildlife Refuge, Michigan

10. Graphs showing graminoid height in control and burn blocks in C3 and Marsh Creek blocks, 2006-10, at Seney National Wildlife Refuge, Michigan.

11. Graphs showing measures of biological diversity detected in control and burn blocks in C3 and Marsh Creek study areas, 2006-10, at Seney National Wildlife Refuge, Michigan.....

12. Graph showing percent open area affected by year $\times$ treatment interactions in control and burn blocks in C3 and Marsh Creek blocks, 2006-10, at Seney National Wildlife Refuge, Michigan......

13. Graph showing percent cover of sedges affected by year $\times$ treatment interactions in control and burn blocks in C3 and Marsh Creek blocks, 2006-10, at Seney National Wildlife Refuge, Michigan.

14. Graph showing percent cover of sedges and rushes affected by year $\times$ treatment interactions in control and burn blocks in C3 and Marsh Creek blocks, 2006-10, at Seney National Wildlife Refuge, Michigan

15. Graphs showing percent cover of grasses affected by separate year and treatment effects in control and burn blocks in C3 and Marsh Creek blocks, 2006-10, at Seney National Wildlife Refuge, Michigan.

16. Graphs showing percent cover of forbs affected by year $\times$ treatment interactions in control and burn blocks in C3 and Marsh Creek blocks, 2006-10, at Seney National Wildlife Refuge, Michigan

17. Graphs showing percent cover of forbs affected by year effects in control and burn blocks in C3 and Marsh Creek blocks, 2006-10, at Seney National Wildlife Refuge, Michigan.

18. Graph showing percent cover of earth loosestrife affected by separate year and treatment effects in control and burn blocks in C3 and Marsh Creek blocks, 2006-10, at Seney National Wildlife Refuge, Michigan.

19. Graph showing percent cover of mosses affected by separate year and treatment effects in control and burn blocks in C3 and Marsh Creek blocks, 2006-10, at Seney National Wildlife Refuge, Michigan.

20. Graph showing percent cover of leatherleaf affected by year $\times$ treatment interactions in control and burn blocks in C3 and Marsh Creek blocks, 2006-10, at Seney National Wildlife Refuge, Michigan.

21. Graphs showing percent cover of woody species affected by year in control and burn blocks in C3 and Marsh Creek blocks, 2006-10, at Seney National Wildlife Refuge, Michigan.....

22. Graphs showing average annual nonmetric dimensional scaling scores for plant community in control and burn blocks in C3 and Marsh Creek, Seney National Wildlife Refuge, Michigan 
23. Graphs showing visual obstruction readings in control and burn blocks for 33-centimeter strata in C3, Seney National Wildlife Refuge, Michigan, 2006-10...........38

24. Graphs showing visual obstruction readings in control and burn blocks for 33-centimeter strata in C3, Seney National Wildlife Refuge, Michigan, 2006-10.

\section{Tables}

1. Fire history, status, and timing of prescribed burning on study blocks in the C3 and Marsh Creek study areas, Seney National Wildlife Refuge, Michigan, 2006-10.

2. Correlations among mean and variability of water depth, litter depth, and graminoid height measures in study blocks in C3 and Marsh Creek study areas, Seney National Wildlife Refuge, Michigan, 2006-10.

3. Results of analysis of variance for habitat and environmental variables on study blocks in C3 and Marsh Creek study areas, Seney National Wildlife Refuge, Michigan, 2006-10

4. Results of analysis of variance for species richness, species diversity index, nonmetric dimensional scaling scores on 3 axes, and percent cover of open, moss, and 27 plant taxa on study blocks in C3 and Marsh Creek study areas, Seney National Wildlife Refuge, Michigan, 2006-10...

5. Pearson correlation coefficients for 27 most common plant taxa with nonmetric dimensional scaling axes in study blocks in C3 and Marsh Creek study areas, Seney National Wildlife Refuge, Michigan, 2006-10

6. Results of analysis of variance for woody taxa height and standard deviation of woody height on study blocks in C3 and Marsh Creek study areas, Seney National Wildlife Refuge, Michigan, 2006, 2007, and 2010.

7. Mean shrub height, variation of height, number of patches, and percent cover for six shrub taxa and total shrub cover at Seney National Wildlife Refuge, Michigan, 2006, 2007, and 2010

8. Results of analysis of variance for percent cover and number of patches of woody taxa on study blocks in C3 and Marsh Creek study areas, Seney National Wildlife Refuge, Michigan, 2006, 2007, and 2010

9. Results of analysis of variance for visual obstruction readings for six height strata on study blocks in C3 and Marsh Creek study areas, Seney National Wildlife Refuge, Michigan, 2006-10

\section{Appendix Tables}

1.1. Crosswalk table of taxonomy of plant species following the Flora of North America (2003) and U.S. Department of Agriculture National PLANTS Database ..........50

2.1. Fire conditions during prescribed burns at Marsh Creek, July 2007 and 2008, and C3, May 2008.

3.1. Frequency of occurrence and percent of points summed across sampling years of plant taxa by block in C3 of Seney National Wildlife Refuge, Michigan, 2006-10

4.1. Frequency of occurrence and percent of points of plant taxa by block in Marsh Creek of Seney National Wildlife Refuge, Michigan, 2006-10 


\section{Conversion Factors}

International System of Units to U.S. customary units

\begin{tabular}{lcl}
\hline \multicolumn{1}{c}{ Multiply } & By & \multicolumn{1}{c}{ To obtain } \\
\hline & Length & \\
\hline centimeter $(\mathrm{cm})$ & 0.3937 & inch (in.) \\
meter $(\mathrm{m})$ & 3.281 & foot $(\mathrm{ft})$ \\
\hline & Area & \\
\hline hectare (ha) & 2.471 & acre \\
square kilometer $\left(\mathrm{km}^{2}\right)$ & 247.1 & acre \\
hectare (ha) & 0.003861 & square mile $\left(\mathrm{mi}^{2}\right)$ \\
square kilometer $\left(\mathrm{km}^{2}\right)$ & 0.3861 & square mile $\left(\mathrm{mi}^{2}\right)$ \\
\hline
\end{tabular}

Temperature in degrees Celsius $\left({ }^{\circ} \mathrm{C}\right)$ may be converted to degrees Fahrenheit $\left({ }^{\circ} \mathrm{F}\right)$ as follows:

$$
{ }^{\circ} \mathrm{F}=\left(1.8 \mathrm{x}^{\circ} \mathrm{C}\right)+32
$$

Temperature in degrees Fahrenheit $\left({ }^{\circ} \mathrm{F}\right)$ may be converted to degrees Celsius $\left({ }^{\circ} \mathrm{C}\right)$ as follows:

$$
{ }^{\circ} \mathrm{C}=\left({ }^{\circ} \mathrm{F}-32\right) / 1.8
$$

\section{Abbreviations}
ANOVA analysis of variance
$\mathrm{BACl}$ before-after-control-impact
NMS nonmetric multidimensional scaling
VOR visual obstruction reading 


\title{
Response of Vegetation in Open and Partially Wooded Fens to Prescribed Burning at Seney National Wildlife Refuge
}

\author{
By Jane E. Austin and Wesley E. Newton
}

\section{Abstract}

The health and function of northern peatlands, particularly for fens, are strongly affected by fire and hydrology. Fens are important to several avian species of conservation interest, notably the yellow rail (Coturnicops noveboracensis). Fire suppression and altered hydrology often result in woody encroachment, altering the plant community and structure. Woody encroachment and its effects on biodiversity have become an increasing concern in the conservation and management of plant communities. This study evaluated the effects of spring and summer prescribed burns on the plant community, cover, and structure in open and partially wooded fens at Seney National Wildlife Refuge, Michigan, using a before-after-control-impact design. Paired, 1-hectare blocks were established in two fen areas, C3 and Marsh Creek, and data were collected for 2 years before burning (2006-7) and 3 years after burning (2008-10). We used generalized linear mixed models and ordination to assess differences among four treatments: C3 control, C3 spring burn (May 2008), Marsh Creek control, and Marsh Creek summer burn (July 2008); results from a block burned under drier conditions in July 2007 also are reported. Variables include water depth; litter depth; graminoid height; species richness and diversity; percent cover of plant taxa, mosses, and open area; shrub height, number of patches, and cover; and visual obstruction readings. The 2008 prescribed burns were done under moderate fire conditions, whereas the 2007 summer burn on one block was done under high fire conditions because of prolonged drought. We identified 104 plant taxa over the 5 years and noted differences between C 3 and Marsh Creek communities. We examined data for effects of treatment, year, and year $\times$ treatment interactions for percent open and the 28 most common taxa. Most differences among treatments were related to natural differences in the plant community and hydrology between the two areas rather than fire effects; year effects were likely related to annual differences in water conditions. We detected few effects of spring burning in C3, even in the same year of burning. In Marsh Creek, most treatment effects were in 2008, when data were collected within 3 weeks of burning. Some fire effects there, however, persisted one to two growing seasons $(2009,2010)$ and two to three growing seasons in the block burned in the more intense summer 2007 fire. Effects of burning on shrub measures were more apparent on summer-burned blocks, but most measures returned to preburn conditions by 2010 . Our results demonstrate the heterogeneity of plant community and environmental conditions of fens within and among years and the interactions of water conditions with burning. The results also demonstrate that neither single spring nor summer burning under moderate fire conditions are effective in setting back woody cover. Maintaining more open conditions in fens may require different approaches to water management, more frequent fires, more aggressive fire management, or a combination of tools to control woody cover.

\section{Introduction}

Peatlands are one of the dominant ecosystem types in the upper Great Lakes, covering roughly 60,000 square kilometers $\left(\mathrm{km}^{2}\right)$ and more than 10 percent of total land area (Boelter and Verry, 1977). They exist in the landscape as part of a matrix of wetland and upland forested communities. Peatlands encompass a variety of habitats, including marsh, bog, open fen, partially wooded fen (intermix of grasses, sedges [Carex], and woody species), and lowland forest. Peatlands are of significant ecological importance because of their role in hydrology, water quality, carbon sequestration, and habitat for wildlife. The health and function of peatlands are strongly affected by fire and hydrology (Vogl, 1969; Rydin and Jeglum, 2006). Fire suppression and altered hydrology often result in the encroachment of trees and shrubs into open fens and bogs, altering vegetation structure and community (White, 1965; Vogl, 1969; Middleton, 2002; Brisson and others, 2006). Increased shrub cover also can disrupt the fire regime by altering microclimate and suppressing development of fine fuels such as graminoids that would carry fire through the system. Alternatively, during dry conditions, the high woody fuel loads in areas of heavy shrub cover can result in fires of higher intensity and greater severity, which are disruptive at site and landscape levels. 
Open and partially wooded fens are important to several species of conservation concern in North America. The yellow rail (Coturnicops noveboracensis) is a rare species associated with shallowly flooded wetlands, most commonly open fens dominated by sedges. Knowledge about its population status in most areas, its basic ecology, and its response to habitat management is limited (Goldade and others, 2002; Austin and Buhl, 2013; Leston and Bookhout, 2015). The species is considered endangered in Michigan and is listed as a priority species in Partners in Flight for the Boreal Hardwood Transition Area (Bird Conservation Area 20) and is a species of conservation concern by the U.S. Fish and Wildlife Service-Region 3 (U.S. Fish and Wildlife Service, 2008). Yellow rail populations are believed to be limited by loss or degradation of wetland habitat because of drainage, altered hydrology, and fire suppression (Committee on the Status of Endangered Wildlife in Canada, 2009; Leston and Bookhout, 2015). Habitat differences relative to fire history, and comparisons between sites with and without yellow rails indicated that yellow rails used areas with the deepest litter and highest ground cover, and low shrub cover and heights, and used landscapes having greater sedge-graminoid cover and less lowland woody or upland cover types (Austin and Buhl, 2013). Fens also are important habitats for LeConte's sparrows (Ammodramus leconteii) and sedge wrens (Cistothorus platensis), both considered priority species for Bird Conservation Area 20. Most information on these two species is based on grassland ecosystems (Dechant and others, 2002a, b), and little data exist regarding their abundance or response to fire, hydrology, or vegetative structure in fens. Understanding what fire regimes or treatments result in preferred habitat conditions is key to managing these peatland habitats for species of conservation concern and for the larger biological community.

Large tracts of fens are in the eastern upper peninsula of Michigan and are exemplified by the habitats within the Seney National Wildlife Refuge (hereafter referred to as "the Refuge"). These habitats commonly host substantial numbers of breeding yellow rails, LeConte's sparrows, and sedge wrens, among other avian species (Bookhout and Stenzel, 1987; J. E. Austin, unpub. data, 2007-09). However, many years of altered fire regimes and hydrology have resulted in encroachment of shrubs into once extensive open fens and bogs and have altered the plant community (Kowalski and Wilcox, 2003; Bork and others, 2013). A key priority of the Refuge, as identified in their Comprehensive Conservation Plan (U.S. Fish and Wildlife Service, 2009), is to restore these habitats back to their historical conditions, primarily through fire management, for the benefit of species such as the yellow rail and LeConte's sparrow. Previous research on burning at the Refuge and elsewhere provided limited data as to the effectiveness of burning to reduce woody encroachment in open fens because they usually examined only spring burns, included only 1 year of data postburn, and had limited data on shrub and community structure (Hanowski and others, 1999; Middleton, 2002; Brisson and others, 2006). Fire conditions and severity were rarely reported, limiting the ability to discern the effects (or lack of effect) of fire on habitat conditions (such as litter) or vegetation community and structure. An earlier yellow rail study at the Refuge indicated that rails avoided areas the first growing season after burning but seemed to prefer them the second growing season after burning, but sample design and sizes were limited (Burkman, 1993). Hence, more detailed investigation of effects of fire on habitat conditions, at least 2 years of data after burning, were needed to begin to evaluate appropriate fire management practices on the plant and shrub community and, in turn, for avian species.

This study was part of a larger project to investigate the avian community of fen habitats in the Refuge in the context of fire (Austin and Buhl, 2013; J. E. Austin, unpub. data, 2007-10). At the heart of the project was this experimental component that examined the effects of prescribed burns on fen habitats using a before-after-control-impact (BACI) design. Our objective was to evaluate effects of prescribed burning in spring versus summer on plant community, plant cover, and vegetative structure in open and partially wooded fens at the Refuge to better inform fire management practices.

\section{Study Area}

The Refuge (lat. $46^{\circ} 15^{\prime} \mathrm{N}$, long. $86^{\circ} 04^{\prime} \mathrm{W}$ ) is in Schoolcraft County on the eastern upper peninsula of Michigan (fig. 1). This region once had about 185,000 hectares (ha) of open sedge-, forb-, and moss-dominated communities before European settlement (Comer and others, 1995; Slaughter and Cohen, 2010). The Refuge's extensive peatlands are primarily open fens (dominated by sedge and other graminoid species), scrub/shrub lowland (wooded fen), and patterned bogs, interspersed with forested sand ridges and knolls (U.S. Fish and Wildlife Service, 2009). The open fens have a diverse community of sedges, grasses, rushes, forbs, Sphagnum and other mosses, and low shrubs, with scattered, sparse patches of broadleaf cattail (Typha latifolia) in some areas. Speckled alder (Alnus incana spp. rugosa), bog birch (Betula pumila), and leatherleaf (Chamaedaphne calyculata) are the most common shrub species. The primary land cover types of nonforested lowlands in the Refuge are scrub/shrub lowland (27 percent), sedge/bluejoint (Carex/Calamagrostis canadensis; 10 percent), Sphagnum/leatherleaf (4 percent), and mixed emergents/grasses/forbs (3 percent) (U.S. Fish and Wildlife Service, 2009). Water conditions in wetlands are affected by natural flow patterns, which move northwest to southeast, and water management of man-made pools, which were constructed in the 1930s. Fens are usually shallowly flooded in spring and remain saturated into the fall. Soils are generally mucks and peats $1-3$ meters $(\mathrm{m})$ in depth, overlaid on wet sand, with interspersed sand dunes. Natural and modified drainages drain the area to the southeast into the Manistique River (not shown). More detailed descriptions of the Refuge landscape and habitats are provided in U.S. Fish and Wildlife Service (2009). 


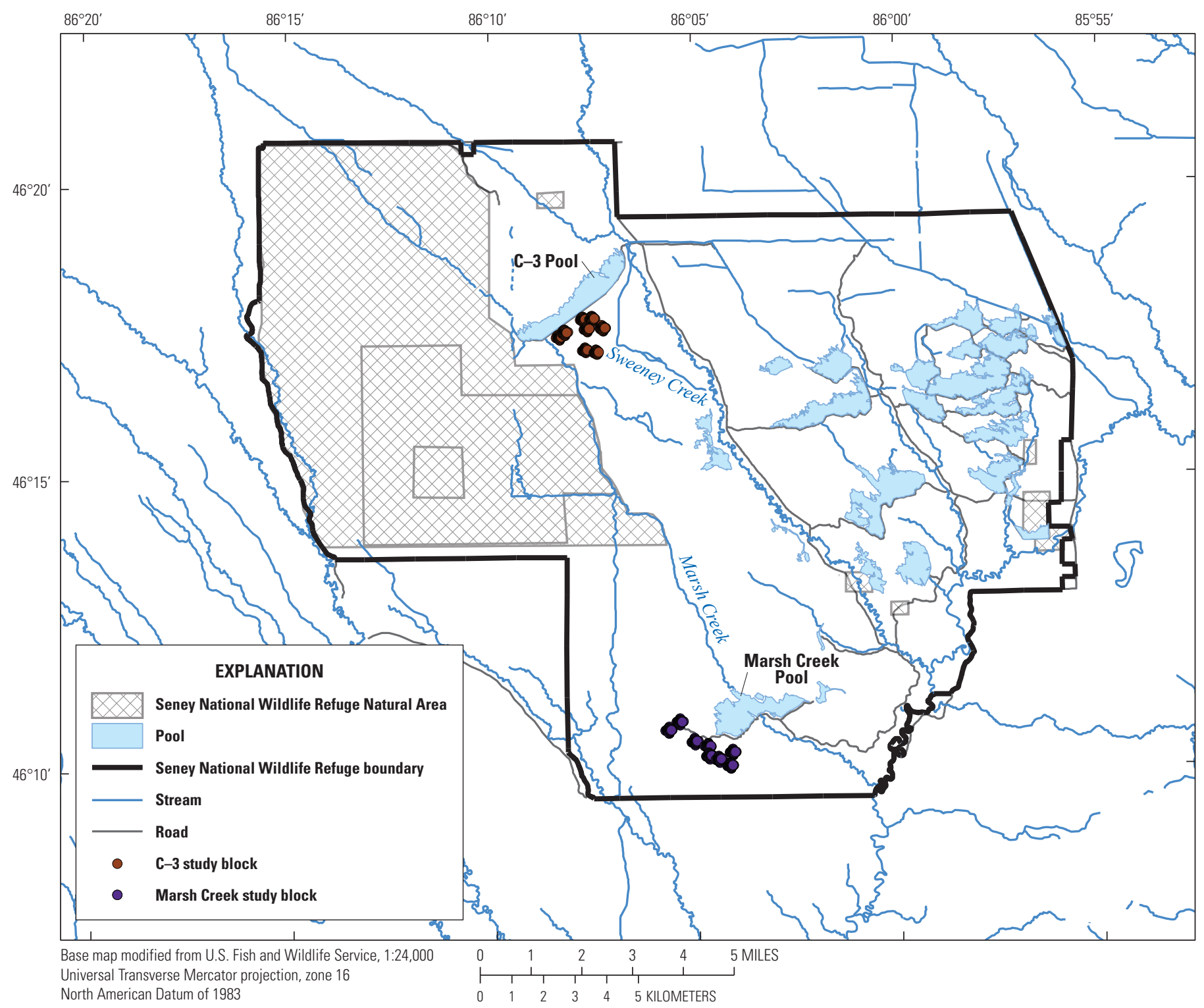

Figure 1. Location of C3 and Marsh Creek study areas in Seney National Wildlife Refuge, in the upper peninsula of Michigan.

Our study focused on two areas in the Refuge that have a long history of research related to yellow rails (Stenzel, 1982; Bart and others, 1984; Burkman, 1993), have extensive fire histories, and were delineated as operational burn units by the Refuge: the area south of C3 Pool (hereafter referred to as "C3") and south of Marsh Creek Pool (hereafter referred to as "Marsh Creek") (fig. 1). These areas were predominantly sedge-bluejoint and scrub/shrub lowland of leatherleaf, speckled alder, and bog birch, with scattered wooded knolls.

The climate of the Refuge is strongly affected by its location between Lake Superior and Lake Michigan (not shown). Average annual precipitation at the Refuge is 78 centimeters (cm); $32 \mathrm{~cm}$ fall during May-September (Michigan
State Climatologist's Office, 2012). Minimum and maximum temperatures range from -2 to 11 degrees Celsius $\left({ }^{\circ} \mathrm{C}\right)$ in April and from 12 to $27^{\circ} \mathrm{C}$ in July, respectively. The median growing season is 125 days (May 27 to September 25). During April-September 2006-10, the region experienced moderate to severe drought in 2006 (Palmer Drought Severity Index, range from -3.88 to -1.72$)$, moderate drought to normal conditions in 2007 ( -3.81 to 0.16 ), and moderately wet conditions in $2008(+2.55$ to +2.70$)$. In 2010, the spring started in moderate to severe drought during March-May ( -4.49 to $-2.46)$, but heavy rains in June followed by consistent rains in July-September resulted in increasingly wet conditions $(+1.56$ to +3.49 ) for the remainder of the growing season. 
Response of Vegetation in Open and Partially Wooded Fens to Prescribed Burning at Seney National Wildlife Refuge

\section{Methods}

\section{Sampling Design and Site Selection}

We used detailed National Land Cover Database data, based on interpretation of 2004 color-infrared aerial images (U.S. Fish and Wildlife Service, unpub. data, 2004), to select locations for eight 1-ha blocks in both C3and Marsh Creek. We first overlaid a $150-\times 150$-m grid (1-ha core plus 25-m buffer around the perimeter) over each area, oriented so that the grid lines were parallel and perpendicular to the predominant flow of water through the area (northwest to southeast). This grid delineated possible $150-\times 150$-m blocks, identified by the Universal Transverse Mercator coordinates of the northernmost corner. Because a primary interest was how fire affected shrubs, we identified blocks that were in lowland shrub (LS-B, 25-60 percent shrub cover; and LS-C, 60-90 percent shrub cover) and that excluded upland types. In each area, 12 to 16 of these blocks were selected at random for field inspection. During preliminary field visits in summer 2006, we visually estimated cover of sedges, grasses, and shrubs and paired blocks based on estimated cover characteristics and proximity. Block pairs were less than $(<) 150 \mathrm{~m}$ from one another to provide some flexibility in fire operations but close enough to be similar in soil and hydrology. After a second round of field inspections, we made the final selection of 8 paired blocks ( 4 pairs in each area) based on field characteristics: 3 pairs of sedge-dominated blocks with low shrub cover, 3 pairs dominated by sedges and grasses with high shrub cover, and 2 pairs with high density of old shrubs (representing extreme conditions of shrub cover) (figs. 2-3). We randomly selected one block in each pair to be burned and the other to serve as a control, as part of the BACI design.

We established our sampling blocks in summer 2006. Each 1-ha block consisted of an outer 25-m buffer area and 25 sampling points distributed in a $5 \times 5$ grid, $25 \mathrm{~m}$ apart (fig. 4). Each sampling point was marked with a short stake topped with an aluminum washer, which allowed field personnel to relocate points each year with a metal detector. We marked the outer four corners of the buffer area and the beginning and end of each of the five transects with tall quaking aspen (Populus tremuloides) poles and flagging. We recorded locations of the four outer corners and each sampling point using a global positioning system receiver (plus or minus $[ \pm]$ 2-3 m). Marking the outer buffer helped fire operations and other field activities to avoid trampling in the block except during data collection and postfire inspection.

Because we chose to fit our experiment within the context of normal fire operations at the Refuge, season of burning was area specific and, thus, was affected by each area's existing plant community and hydrology. Both C3 and Marsh Creek, however, have similar effects from managed pools and levees and similar fire histories; only one pair of blocks had been burned within the previous 5 years (table 1).

\section{Data Collection}

We collected full plant data on all eight blocks in Marsh Creek and six blocks in C3 during 2006-10. This BACI design provided for data collection two growing seasons before the burn (2006 and 2007) and three growing seasons (2008, 2009, and 2010) after burning; the unburned plot of each pair served as the control, and the burned plot of each pair the treatment (table 1). Data for MC-2, the only block burned in 2007, were excluded from analyses, but results are presented for comparison. We collected data during mid-July to early September each year, when plants had likely reached their maximum growth and before killing frosts. Data collection within that period was alternated between the two areas to minimize possible temporal effects. Information of water depths in May was obtained from a concurrent study (Austin and Buhl, 2013) at locations within $50 \mathrm{~m}$ of each block.

Data on plant cover (to species), litter depth, and graminoid height were recorded at each sample point using a modified point-intercept method (Elzinga and others, 1998). Field identification followed Crow and Hellquist (2000a, b), Chadde (2002), and Flora of North America Editorial Committee (2003). Taxonomy used here follows the National PLANTS database (U.S. Department of Agriculture, Natural Resources Conservation Service, 2017; see appendix 1 for a crosswalk table of scientific and common names of plant taxa found, for the PLANTS database as of the date accessed and Flora of North America Editorial Committee, 2003). We merged some species to genera where we were unable to consistently identify to species (Eriophorum, Equisetum, Galium, Rubus, Salix, and Vaccinium). Sphagnum was the dominant moss in both areas, but we did not distinguish this group from other mosses. We included creeping bentgrass (Agrostis stolonifera) with bluejoint because the two grass species were often difficult to separate without seed heads. A 2-m transect was $1 \mathrm{~m}$ southeast from each sample point. Each species touching along a single edge of a transect was recorded within each of $405-\mathrm{cm}$ segments. For each segment, we also recorded the presence/ absence of Sphagnum and other mosses and open area (no vegetation or litter). At every fifth segment (eight measures per sampling point), we also recorded litter depth (in centimeters), height of litter above the solid substrate) and graminoid height (in centimeters) by firmly setting the end of a meter tape onto the substrate below any litter. Metrics were expressed as a percentage (number of hits per 40 segments) for each sample point. Graminoid height reflected actual plant height; points with no graminoids were excluded from analyses.

Shrubs in this community often have multiple stems, and the line-intercept method used for herbs (as described above) would not accurately reflect their canopy cover. We instead used shrub patch number and shrub patch size (Harrell and Fuhlendorf, 2002) to provide a measure of shrub occurrence, cover, and height by species as well as a measure of horizontal patchiness. These measures are similar to those used by 


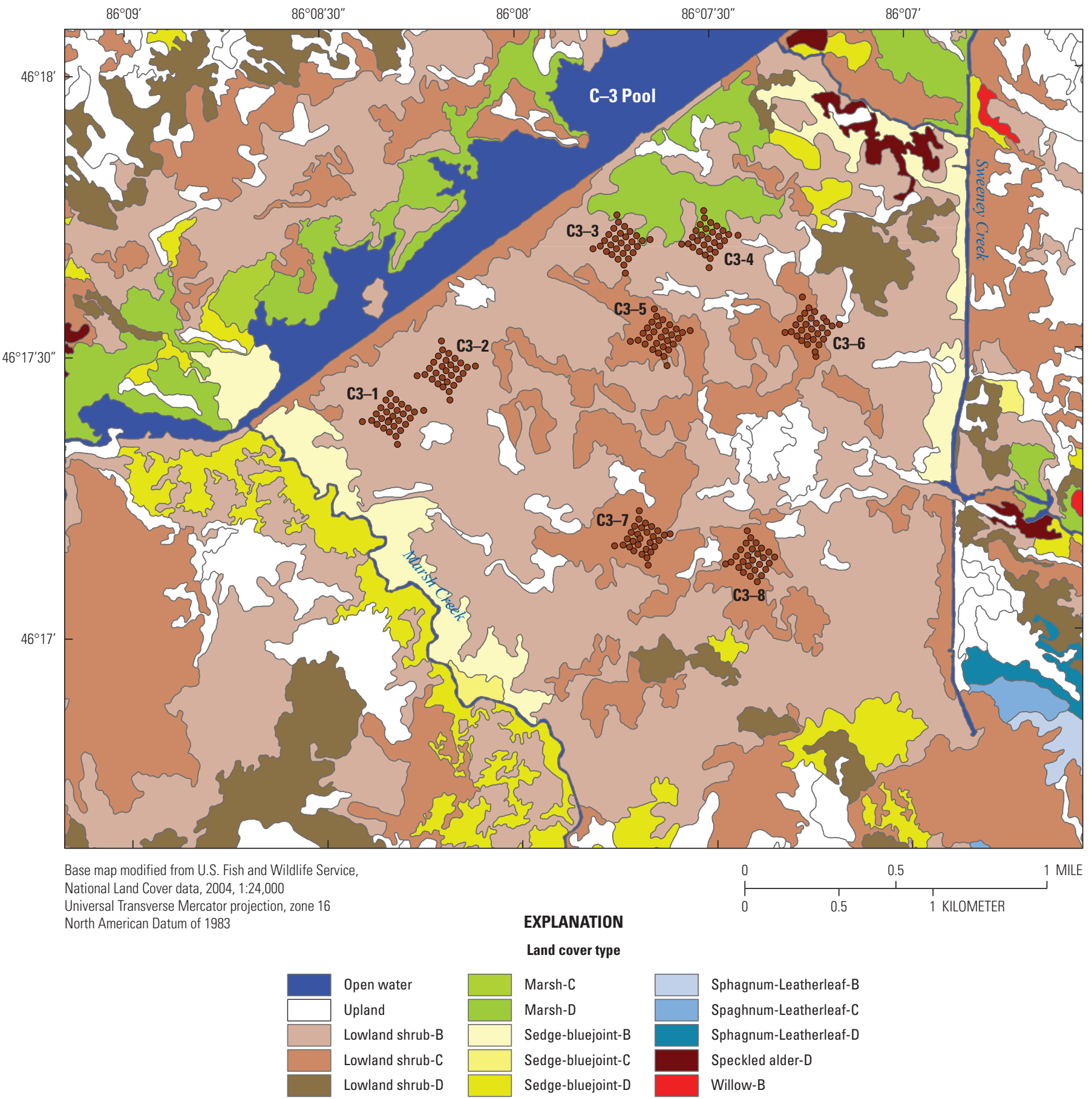

Figure 2. Location of study blocks at the C3 study area relative to cover types in Seney National Wildlife Refuge, Michigan. For cover types, $B$ indicates $25-60$ percent cover of the dominant vegetation; $C$ indicates $60-90$ percent cover of the dominant vegetation, and $\mathrm{D}$ indicates 100 percent cover of the dominant vegetation. Land cover data from the U.S. Fish and Wildlife Service.

White (1965) to measure importance of shrub species. We located a 5-m transect $1 \mathrm{~m}$ northwest of each sampling point, laid adjacent to the baseline transect to minimize trampling effects. We used standard line-transect methods (Elzinga and others, 1998) to record the length of each shrub patch (to the nearest centimeter) along each transect for each species. A distinct shrub patch was defined as greater than or equal to $10 \mathrm{~cm}$ long and continuous (canopy break $<10 \mathrm{~cm}$ ). We also recorded lengths of overlap of cover between shrub species and maximum height of each shrub patch (to the nearest $5 \mathrm{~cm}$ ). For each sampling point, we summarized shrub data as average patch height, size, and number of patches and 

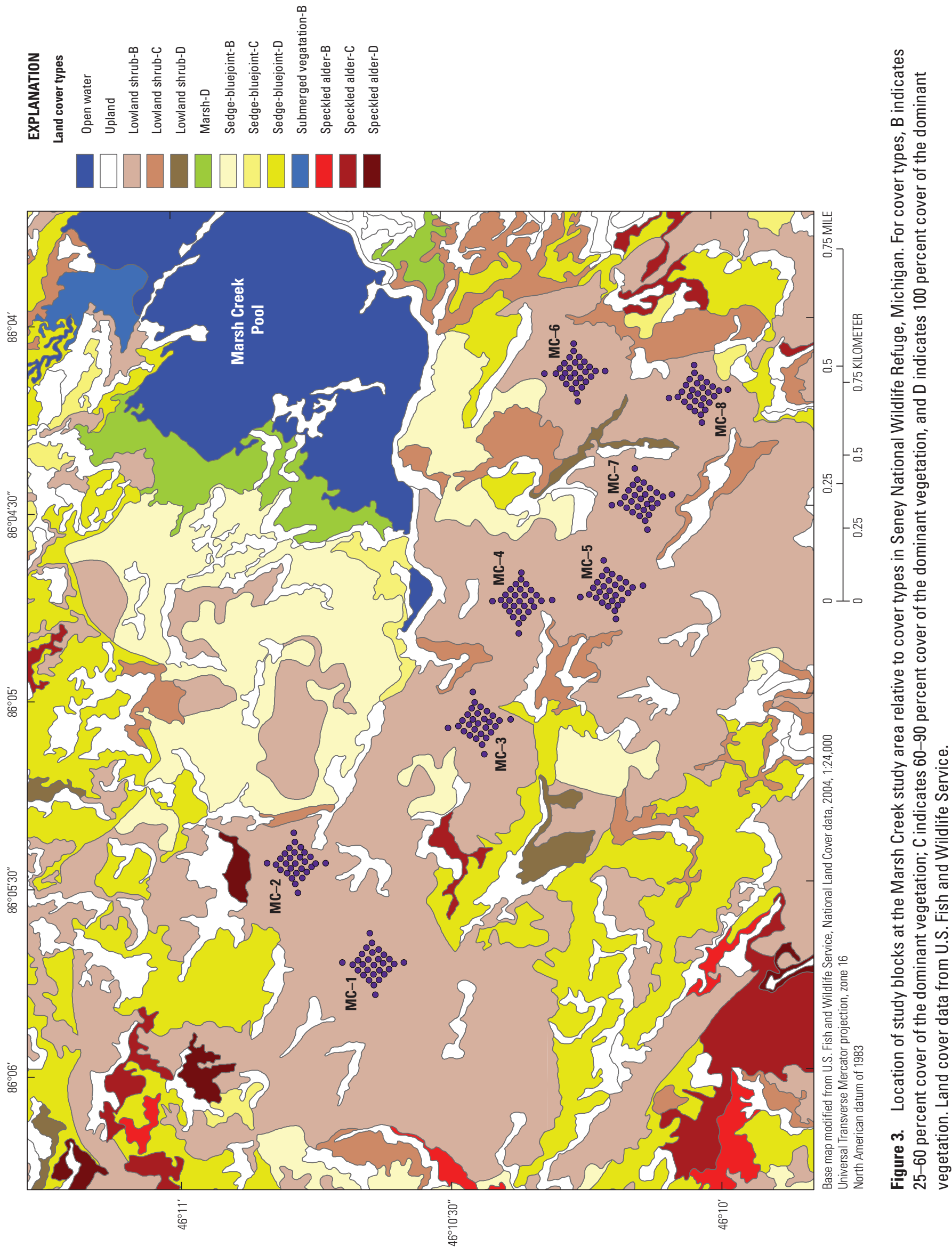


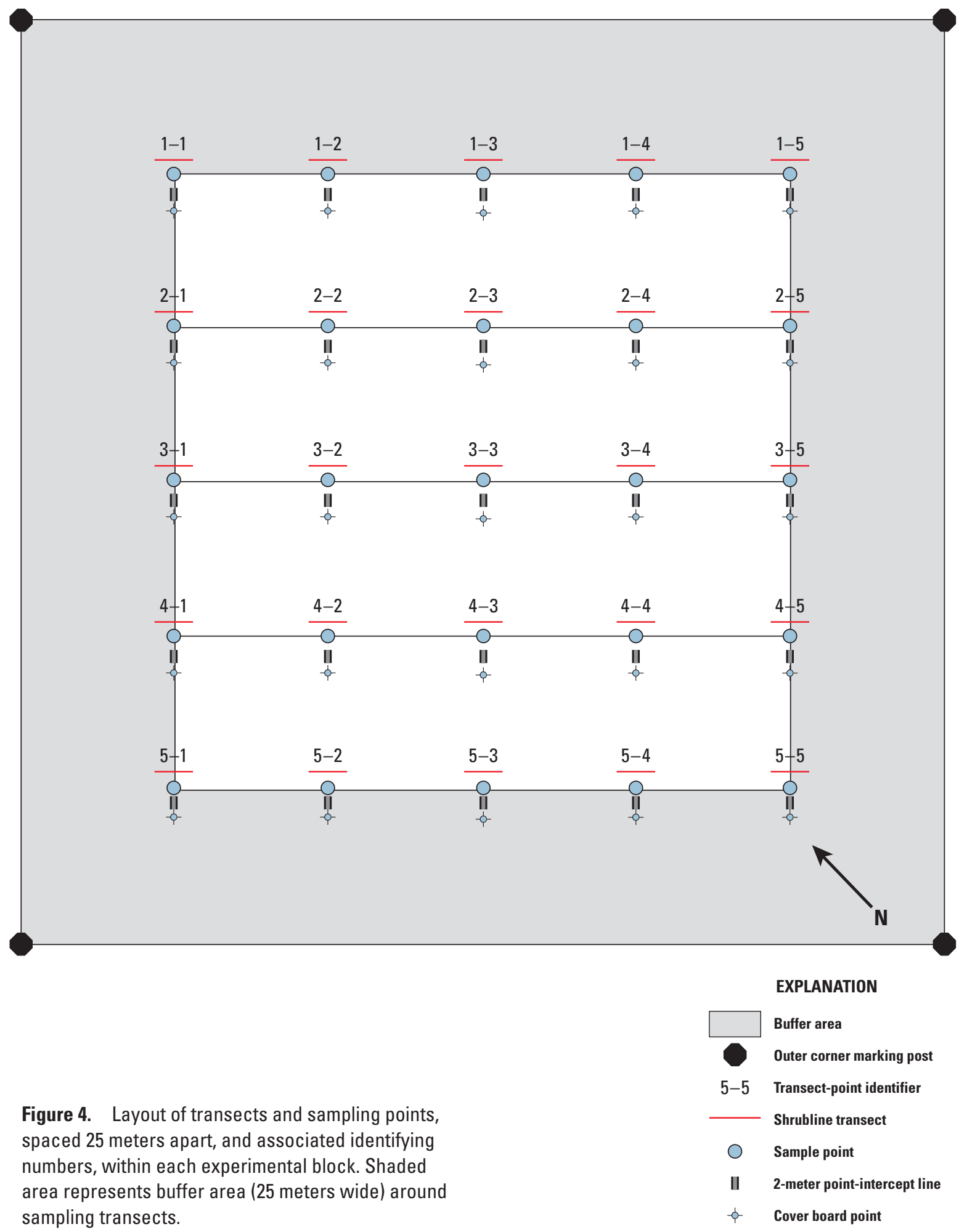

percent cover (summed length per $500 \mathrm{~cm}$ ) by species. For each species, we summarized data as average patch height, size, and number, and percent cover (summed length $/ 500 \mathrm{~cm}$ ). We also calculated total percent shrub cover (summed lengths of each species minus overlaps $/ 500 \mathrm{~cm}$ ) and overall average height and number of shrub patches (expressed as number per 5-m transect).
Vertical cover or visual obstruction of the vegetation was measured using a cover board (Nudds, 1977), $30 \mathrm{~cm}$ wide, $1.5 \mathrm{~m}$ tall, and marked in six $33-\mathrm{cm}$ vertical increments, or "strata," demarked by alternating white and red strips. The observer placed the cover board $1 \mathrm{~m}$ beyond the 2 -m plant sampling line and estimated the percent of each stratum not visible (visual obstruction reading [VOR]) from $5 \mathrm{~m}$ away in 
Table 1. Fire history, status, and timing of prescribed burning on study blocks in the C3 and Marsh Creek (MC) study areas, Seney National Wildlife Refuge, Michigan, 2006-10.

[Pre, pretreatment; numbers in 2008-10, the number of growing seasons postburn]

\begin{tabular}{|c|c|c|c|c|c|c|}
\hline Block & $\begin{array}{c}\text { Year of previous } \\
\text { fire }\end{array}$ & 2006 & 2007 & 2008 & 2009 & 2010 \\
\hline $\mathrm{C} 3-1$ & 2003 & Pre & Pre & Control & Control & Control \\
\hline C3-2 & 2003 & Pre & Pre & Burned May 8 & 1.5 & 2.5 \\
\hline C3-3 & 1976 & Pre & Pre & Burned May 8 & 1.5 & 2.5 \\
\hline C3-4 & 1976 & Pre & Pre & Control & Control & Control \\
\hline $\mathrm{C} 3-5$ & 1976 & Pre & Pre & Burned May 8 & 1.5 & 2.5 \\
\hline C3-6 & 1976 & Pre & Pre & Control & Control & Control \\
\hline $\mathrm{MC}-1$ & 1992 & Pre & Pre & Control & Control & Control \\
\hline $\mathrm{MC}-2$ & 1992 & Pre & Burned July 17 & 1 & 2 & 3 \\
\hline $\mathrm{MC}-3$ & 1991 & Pre & Pre & Control & Control & Control \\
\hline $\mathrm{MC}-4$ & 1976 & Pre & Pre & ${ }^{1}$ Control & Control & Control \\
\hline $\mathrm{MC}-5$ & 1976 & Pre & Pre & Burned July 24 & 1 & 2 \\
\hline MC-6 & 1976 & Pre & Pre & Control & Control & Control \\
\hline $\mathrm{MC}-7$ & 1976 & Pre & Pre & Burned July 24 & 1 & 2 \\
\hline MC-8 & 1976 & Pre & Pre & Control & Control & Control \\
\hline
\end{tabular}

${ }^{1} \mathrm{MC}-4$ was originally designated as a burn block in the study design but would not burn during the 2008 fire and, therefore, was reclassified as a control block for analyses.

each of the four cardinal directions. The four readings for each sampling point were averaged for each stratum.

\section{Prescribed Burn Treatments}

Prescribed burns in each study area (Refuge burn unit) were implemented following normal Refuge operations. Blocks assigned to the control treatment were prevented from burning by compacting the vegetation around the block (outside the buffer area) into existing surface moisture using a large tracked, amphibious vehicle that exerted low ground pressure (1.0-1.5 pounds per square inch). The compaction line was monitored during the fire, and creeping fire was extinguished with water as needed to prevent fire intrusion. Burned blocks were allowed to burn normally as part of the larger fire operation. The burns were completed using ground ignition using drip torches to create a backing and flanking fire around the perimeter followed by a head fire, with additional fire application applied as needed. Weather parameters during the burns (appendix table 2.1) were recorded hourly on site and at the Refuge's remote automated weather station (available at Great Lakes Fire and Fuels, https://glff.mesowest.org); additional observations were recorded periodically in the field.

Within 7 days after each burn, we recorded fire effects to vegetation, Sphagnum, and litter and noted moisture conditions. We visually estimated burn severity and percent of the block affected for the main fuel types (graminoids and forbs, leatherleaf, speckled alder, bog birch, willow [Salix], tamarack
[Larix laricina], Spirea, and other). Burn severity for each type was categorized as unburned, scorched, lightly burned, moderately burned, or heavily burned (National Park Service, 2003). We also visually estimated how much of the litter layer was consumed ([1] all of that year's growth and last year's litter, [2] also consumed 2-year-old litter [partially degraded material but stems still visible], [3] only undefined peat mat remained, [4] ashed down to nonpeat substrate). We rated how the burn affected Sphagnum ([1] surface singed or lightly burned but green still visible on surface; [2] surface burned but interior still green; [3] burned, no green detected in interior, at least partially consumed). Average water conditions in the block were recorded for water depth (in centimeters above the surface) for pooled water; water conditions of coarse surface peat $(0-10 \mathrm{~cm}$ below surface) and fine-particle subsurface peat (greater than $[>] 10 \mathrm{~cm}$ below surface) were categorized as saturated to dry. We also noted the phenological status of vegetation (for example, bud development, leave emergence, and height of new nonwoody growth in spring; stage of senescence or leaf fall in autumn) immediately before the burn.

The $\mathrm{C} 3$ burn unit was burned in early spring under moderate fire conditions for spring (appendix table 2.1). At the time of the fire, new growth of graminoids was $3-10 \mathrm{~cm}$ high, leaf buds of shrubs were beginning to break, and willows had partially opened catkins. Surface and subsurface peat were saturated, and some areas had surface water as much as $5 \mathrm{~cm}$ deep. Postburn inspections of the burned blocks (fig. 5) indicated 95-98 percent of current nonwoody vegetation and 

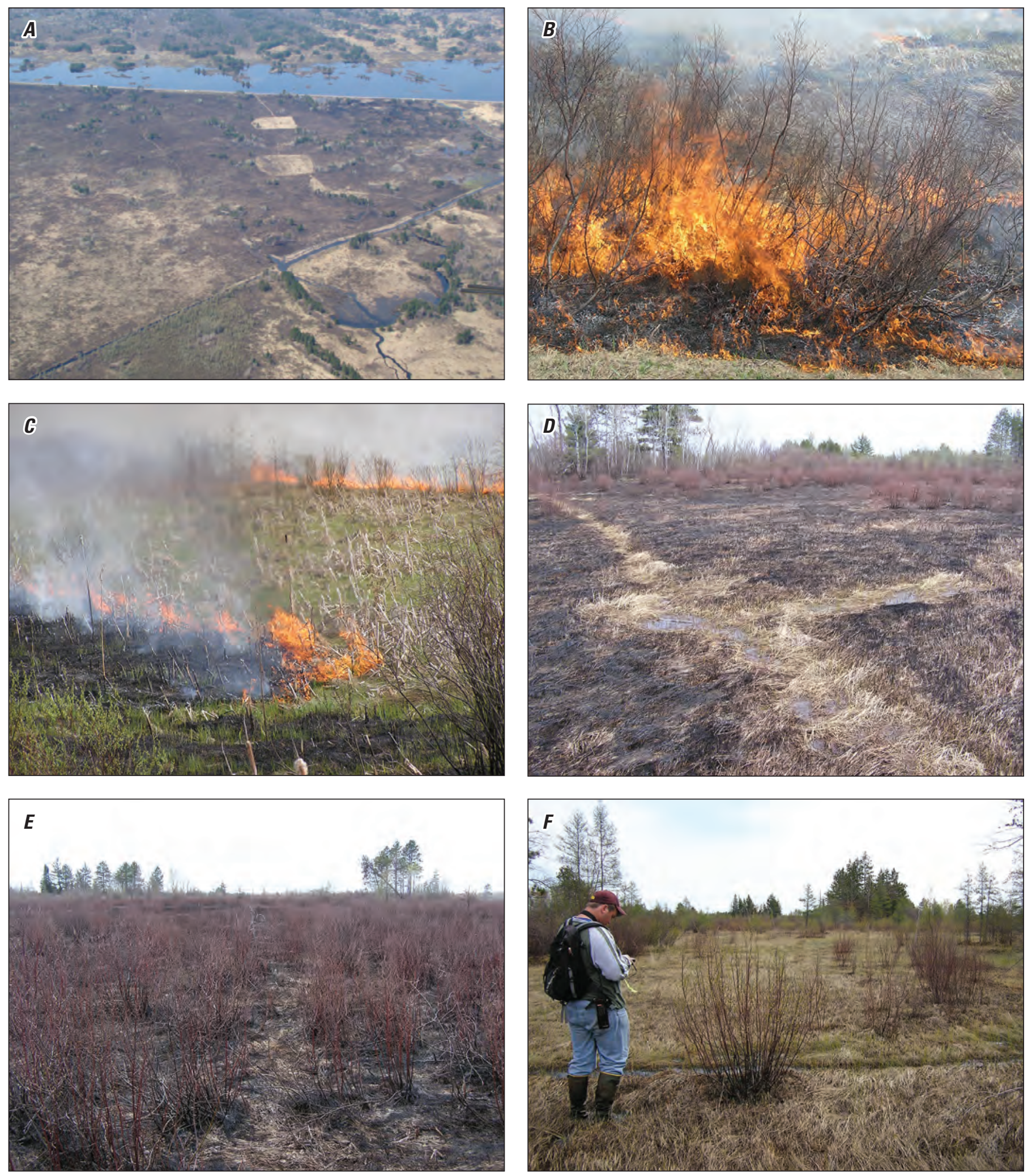

Figure 5. Conditions after the prescribed burn on the C3 study area, May 2008. A, Aerial photograph of the C3 study area and pool; $B$, alder brush torching; $C$, fire front moving through sedge and cattail; $D$, transect line in $C 3$ showing effect of foot traffic on litter consumption; $E$, scorched shrubs in C3 the day after the burn; $F$, technician examining conditions in an unburned block 1 month after the C3 burn. Aerial photograph by the Michigan Department of Natural Resources; other photographs by J.E. Austin, U.S. Geological Survey. 
50-75 percent of the previous year's litter were consumed, 80-100 percent of shrubs were scorched, and most Sphagnum hummocks were only singed or the top burned. Fire did not carry into C3-7 because of heavy shrub cover, low amount of fine fuels, and damper microclimate. Because we were unsuccessful in that burn treatment and constrained by man-hours, we dropped the paired C3-7 and C3-8 blocks from subsequent data collection and data analyses.

Two summer burns were completed. The Marsh Creek burn unit was planned as a summer 2007 burn. A 21-ha area encompassing MC-2 was burned on July 17, 2007, under high fire danger conditions for summer (table 1, fig. 6; appendix table 2.1). Surface and subsurface peat were damp but not saturated (some water drops emitted when a sample was compressed), and no surface water was present; pooled water was detected $12 \mathrm{~cm}$ below the surface. Postburn inspection indicated a burn of moderate severity: 90-100 percent of the nonwoody vegetation and the previous year's litter were
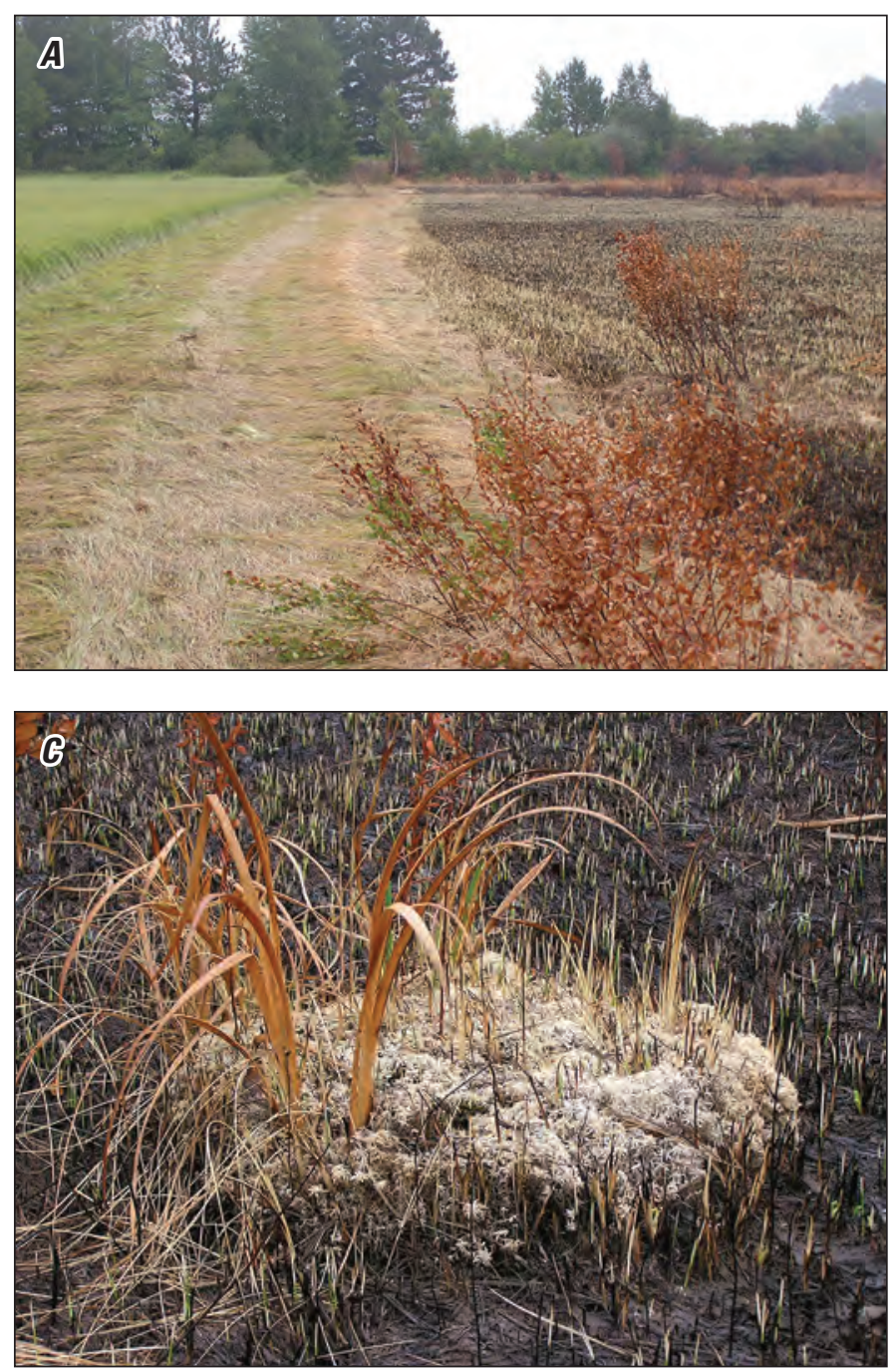

consumed, 50-80 percent of shrubs were scorched or lightly burned, and 60 percent of Sphagnum clumps were burned. Most Sphagnum hummocks were either surface burned (30 percent) or burned ( 60 percent). The Refuge was unable to safely burn the rest of the Marsh Creek unit as planned that year because of intensification of drought conditions and large wildfires in the region. The remaining parts of that burn unit were burned on July 24, 2008, under moderate conditions for summer (table 1, fig. 7; appendix table 2.1). Surface and subsurface peat were saturated, and some areas had surface water as much as $7 \mathrm{~cm}$ deep. Postburn inspection of blocks indicated that $\mathrm{MC}-5$ and $\mathrm{MC}-7$ experienced light to moderate burns, with variable burn severity. An estimated 80 to 90 percent of current nonwoody vegetation and the previous year's litter were consumed, and 70-80 percent of Sphagnum clumps were surface burned. Most shrubs were unburned or scorched, but 25-30 percent of leatherleaf was severely burned compared to $0-10$ percent for alder, birch, and willow.
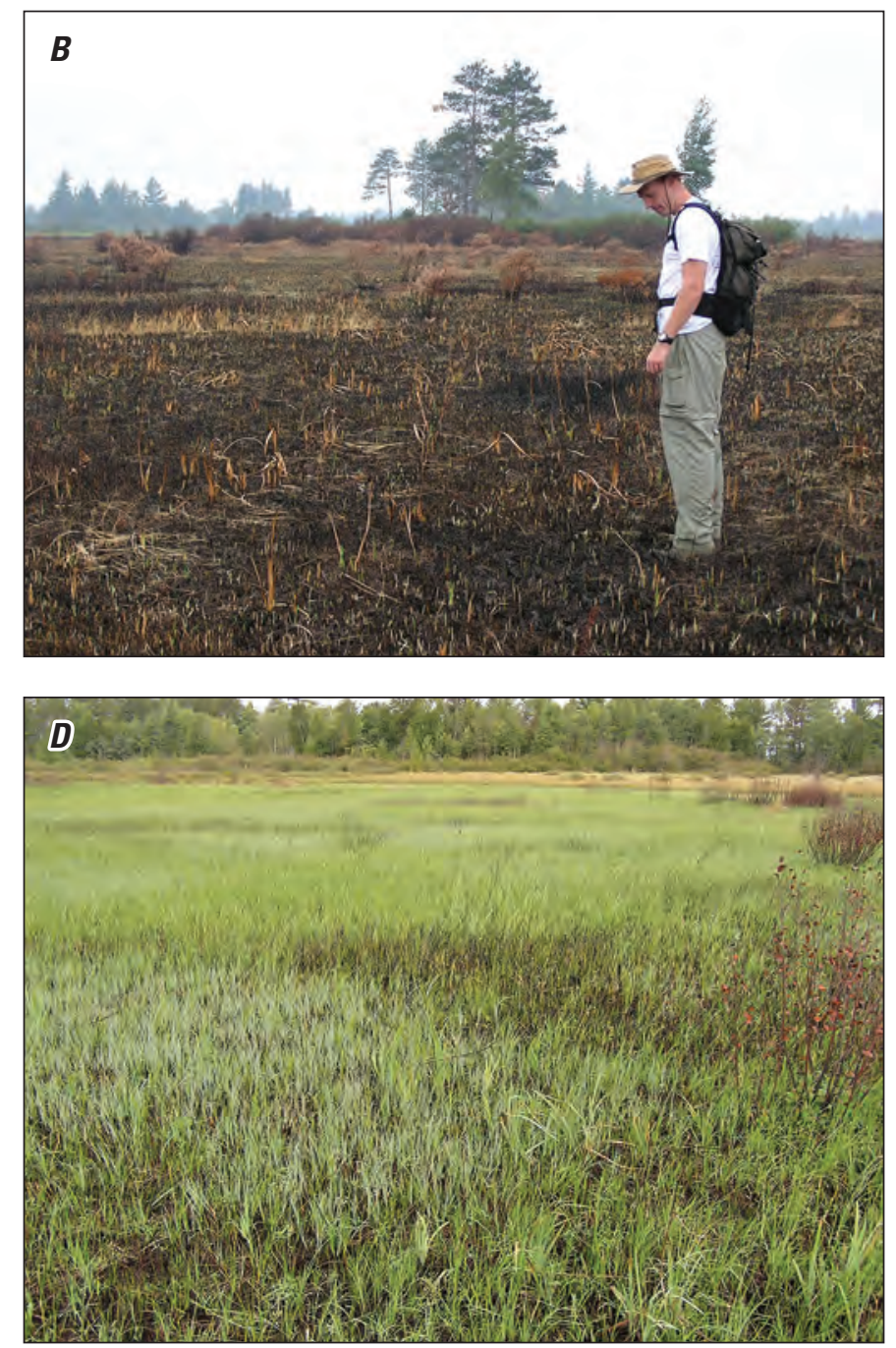

Figure 6. Conditions after the prescribed burn on the MC-2 block of the Marsh Creek study area, July 2007. $A$, Fire line between burned and unburned vegetation, established using an amphibious track vehicle; $B$, botanist examining results of newly burned MC-2 block; $C$, burned Sphaghum clump; $D$, green-up of vegetation by September. Photographs by J.E. Austin, U.S. Geological Survey. 

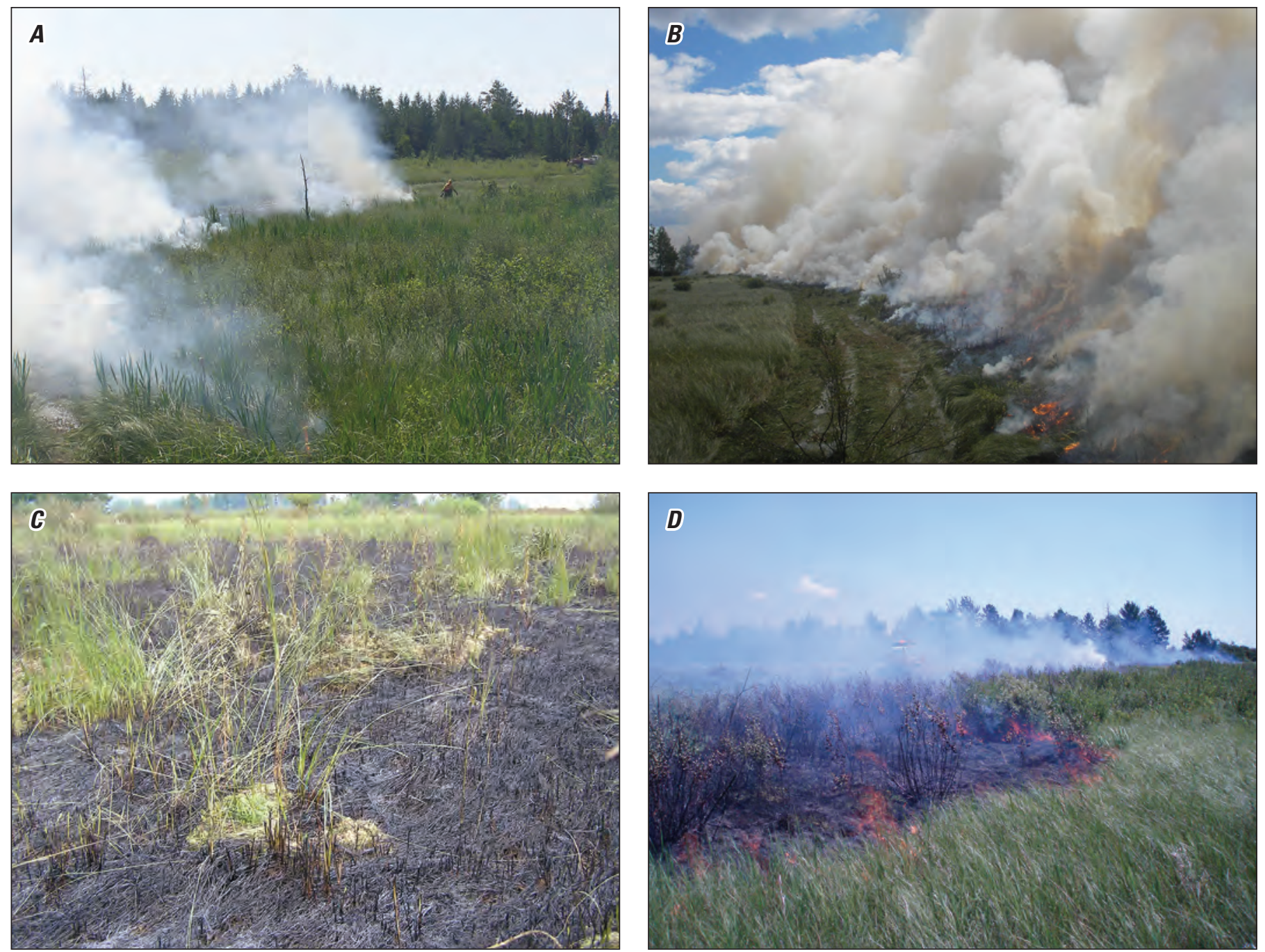

Figure 7. Conditions after prescribed burn on the Marsh Creek study area, July 2008. $A$, Fire crew using drip torches to ignite vegetation the burn perimeter; $B$, initial fire conditions along the east fire-line perimeter of the burn; $C$, patchy consumption of green vegetation; $D$, fire advancing through shrubs and graminoids; E, color-infrared aerial photograph of Marsh Creek about 1 week after burning; reddish colors indicate green vegetation (unburned areas). Aerial photograph by the U.S. Fish and Wildlife Service; other photographs by J.E.

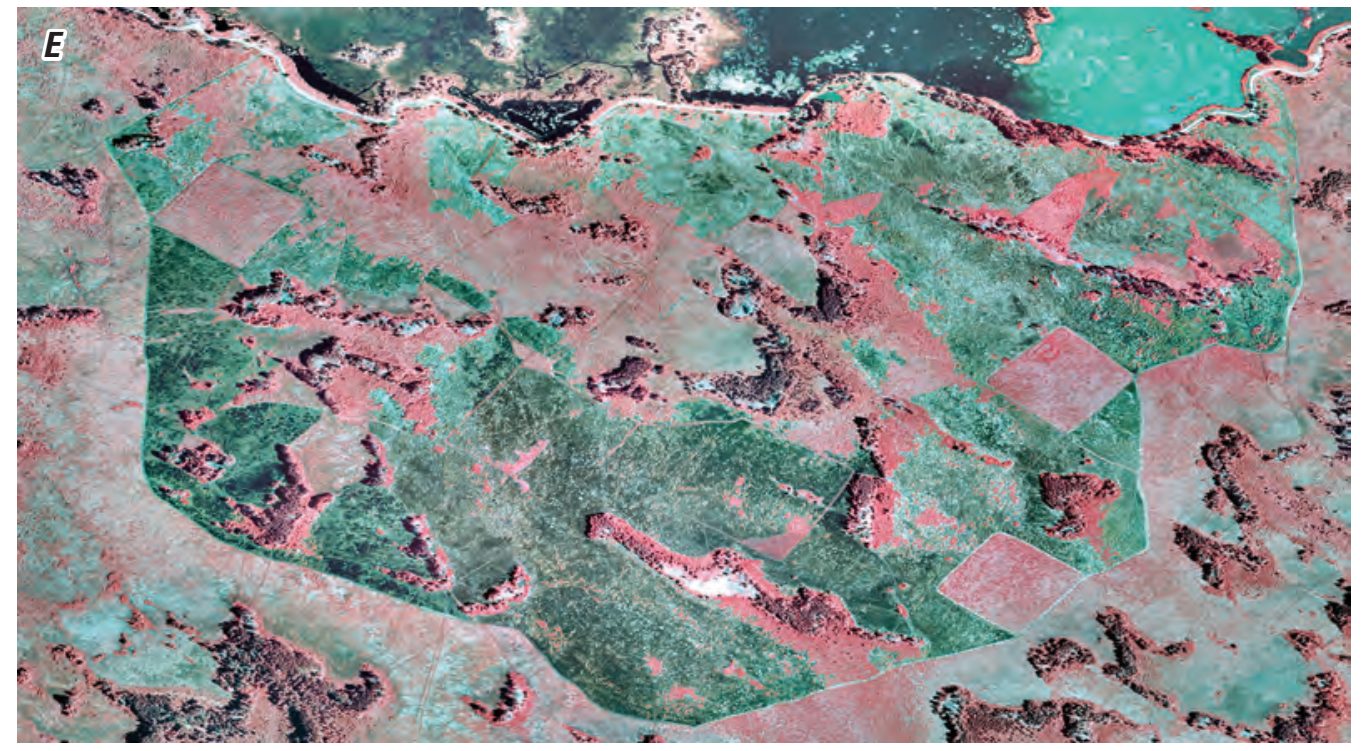
Austin, U.S. Geological Survey. 
$\mathrm{MC}-4$, in contrast, was burned lightly only on its western edge despite the absence of surface water and repeated efforts to ignite fuels in the block. In that block, 90 percent of graminoids and forbs and $85-100$ percent of shrubs were unburned, and only 10 percent of the 2-year-old litter was consumed; 5 percent of Sphagnum hummocks were singed and 5 percent were surface burned; hence, this block was redesignated as a control block for analyses.

\section{Data Analyses}

In general, the study design would be considered a repeated-measures design with various levels of subsampling completed within each block depending on the specific response variable quantified (Milliken and Johnson, 2009). The study also is in a BACI design (Underwood, 1991). Here, the 1-ha blocks (that is, study plots) are considered random and nested within each of the four treatments ( $\mathrm{C} 3$ unit spring treatment includes $\mathrm{C} 3$ control and $\mathrm{C} 3$ spring burn; Marsh Creek unit summer treatment includes $\mathrm{MC}$ control and $\mathrm{MC}$ summer burn). As noted above, $\mathrm{MC}-2$ was excluded from analyses because it was burned in 2007 rather than with the other burn treatments in 2008, MC-4 was reclassified as a control because it was only slightly burned on one edge, and the paired $\mathrm{C} 3-7$ and $\mathrm{C} 3-8$ blocks were dropped because fire did not penetrate $\mathrm{C} 3-7$. The following blocks were used in analyses:

- C3 spring burn includes C3-2, C3-3, C3-5 (number of samples $[n]=3$ )

- C3 control includes C3-1, C3-4, C3-6 (n=3)

- MC summer burn includes MC-5, MC-7 ( $n=2)$

- MC control includes MC-1, MC-3, MC-4, MC-6, $\mathrm{MC}-8(n=5)$

We considered the 5 baseline transects (which ran perpendicular to the general water-flow gradient), the 5 sampling points along each transect, and the $405-\mathrm{cm}$ segments within transect-point locations (where applicable) as subsamples within each study block. With the exception of the environmental variables water depth, litter depth, and graminoid height, all response variables and analyses were summarized across these subsamples to compute means and standard deviations at the block level because the blocks are considered the experimental unit for the burn and control treatments. Transect was incorporated as a factor in analyses for water depth, litter depth, and graminoid heights because we were interested in assessing a gradient effect within the study areas. The pairing of study blocks within $\mathrm{C} 3$ and $\mathrm{MC}$ was not used in analyses. Year was considered the repeatedmeasures factor because each block was measured across 5 years (2006-10): 2 pretreatment years (2006-7) and 3 postburn years (2008-10). Because the VOR was quantified at six height levels at each sampling point, height was considered a third factor in a split-plot structure.

For analyses, we combined data for some closely related or similar species, resulting in 96 taxa in analyses:

- CAREX includes Carex lasiocarpa, C. oligosperma, C. interior, and four narrow-leaved Carex species that could not be identified to species (recorded in 2006 and 2007); hereafter referred to collectively as "narrowleaved sedges."

- CARAQU includes Carex aquatilis and an unknown wider-leaved Carex found in 2006.

- CALCANAG includes Calamogrostis canadensis and Agrostis stolonifera.

- ERIOPH includes cottongrasses Eriophorum angustifolium and E. viridicarinatum.

- GALIUM includes bedstraws Galium labradoricum and G. trifidum.

- RUBUS includes all Rubus berries (Rubus acaulis, R. hispidus, R. pubescens, and unidentified Rubus species).

- SALIX includes all willows (Salix).

- VACCIN includes all blueberries (Vaccinium macrocarpon, V. myrotillides, and unidentified Vaccinium species).

- VIOLAS includes violets Viola nephrophylla and V. macloskeyi.

We developed specific contrasts for a priori planned comparisons among the treatments while utilizing all data from all blocks (Milliken and Johnson, 2009). We analyzed only those taxa that were detected more than 100 times in the 65,000 total sampling points-by-year combinations. For each area, we did within- and across-year comparisons of control and burn blocks when analysis of variance (ANOVA) results indicated significant effects or interactions. To accommodate the repeated measures on the blocks, we assumed an autoregressive lag 1 error structure in generalized linear models for ANOVAs (Littell and others, 2007). When numerical convergence was present, we used the Kenward-Roger correction to degrees of freedom to accommodate the unequal number of blocks per treatment and the random effects for all ANOVAS (Stroup, 2012); no adjustments were made when numerical computations would not converge. Preliminary analyses did not indicate consistent spatial correlation within and among blocks, so we did not make any accommodations for this in the ANOVAs (Gbur and others, 2012). We used SAS software (SAS Institute, Inc., 2013) to complete all data processing and analyses, in particular, the generalized linear mixed model procedure (PROC GLIMMIX). We assumed a beta distribution for all percentage response variables and normality for all others (Gbur and others, 2012). Because of inconsistencies 
in methods of shrub data collection in 2008 and 2009, those 2 years were excluded from analyses of shrub cover data.

We also examined simple correlations among the means and standard deviations of the three habitat variables (water depth, litter depth, and graminoid height).

Shifts in plant community composition were examined using nonmetric multidimensional scaling (NMS) ordinations of mean plant cover from each block-by-year combination. We reduced the effect of very uncommon plant species by only using species that were detected in more than 3 percent of total sampling points within each block. As with other response variables, NMS axis scores also were used in ANOVAs to assess burn effects on the plant community in general; correlations with individual plant taxa were used to guide interpretation of the axes. For descriptive purposes, we plotted the NMS scores of three axes and connected succeeding years of each of the four treatments with arrows to examine trends over time in plant communities. Because NMS axes are linear, we could estimate changes from year to year by subtracting NMS scores from one year to the succeeding year (for example, 2007, before burning, to 2008, after burns). The unit measures of scores or the change in scores themselves do not carry meaning; rather, we were interested in the magnitude of the change from zero and in comparing that magnitude relative to that of idle control plots. We used the program PC-ORD (McCune and Mefford, 2011) with Sorensen distance measure in the NMS ordination. We followed guidelines in Peck (2010) to determine dimensionality of the NMS by utilizing default settings in PC-ORD from multiple runs under medium autopilot settings.

Data analyzed during this study are available as a U.S. Geological Survey data release (Austin, 2018).

\section{Results}

\section{Environmental and Habitat Variables}

As expected, means of water depth, litter depth, and graminoid height were strongly correlated with their respective standard deviations ( $r ; r=0.48$ to 0.92 ); however, only moderate correlations were detected among these variables (table 2). Notably, mean and variability of litter depth were correlated with mean and variability of water depth $(r=0.34$ and 0.53 , respectively; $p<0.01$ ).

The year $\times$ treatment interaction was significant for both means and within-block standard deviations (hereafter referred to as "variability") of water depth, litter depth, and graminoid height (table 3), indicating differences among the treatments varied with year. The water-flow gradient within each block (across the five baseline transects) was not significant $(p>0.05)$, nor did it interact with year or treatment.

Water depth patterns in both areas were generally similar among treatments, with little standing water in summer 2006, 2007, or 2009; some standing water in 2008; and highest levels of standing water in 2010. Similarly, May water conditions, measured in each study area during yellow rail surveys (J.E. Austin, unpub. data, 2009), were highest in 2008 (7.2 and $6.6 \mathrm{~cm}$ for C3 and Marsh Creek, respectively) and 2009 (4.4 and $7.3 \mathrm{~cm}$ for $\mathrm{C} 3$ and Marsh Creek, respectively) and lowest in 2007 (3.0 and $1.1 \mathrm{~cm}$ for C3 and Marsh Creek, respectively). Ancillary information indicates May water depths in 2006 were similar to those in 2007, and those in 2010 were similar to or higher than those measured in 2008. Mean and variability of water depth within years and areas did not differ between the burn and the control blocks (fig. 8). In 2010, summer-burned blocks in Marsh Creek had a somewhat higher mean water depth $(4.85 \pm 0.44$ versus $3.09 \pm 0.28 \mathrm{~cm})$ and variability ( $3.63 \pm 0.25$ versus $2.45 \pm 0.16)$ than control blocks there.

Table 2. Correlations among mean and variability (standard deviation) of water depth, litter depth, and graminoid height measures in study blocks in C3 and Marsh Creek study areas, Seney National Wildlife Refuge, Michigan, 2006-10.

[The probability ( $p$-value) is in parentheses; the number of samples is 325 block by treatment by transect combinations. ${ }^{*}$, significant at $\alpha=0.05$; --, no data]

\begin{tabular}{|c|c|c|c|c|}
\hline Mean litter depth & Mean graminoid height & $\begin{array}{c}\text { Standard deviation, } \\
\text { water depth }\end{array}$ & $\begin{array}{c}\text { Standard deviation, } \\
\text { litter depth }\end{array}$ & $\begin{array}{l}\text { Standard deviation, } \\
\text { graminoid height }\end{array}$ \\
\hline \multicolumn{5}{|c|}{ Mean water depth } \\
\hline $0.34(<0.01)^{*}$ & $-0.06(0.26)$ & $0.92(<0.01)^{*}$ & $0.49(<0.01)^{*}$ & $0.08(0.13)$ \\
\hline \multicolumn{5}{|c|}{ Mean litter depth } \\
\hline-- & $0.11(0.04)^{*}$ & $0.32(<0.01)^{*}$ & $0.71(<0.01)^{*}$ & $0.27(<0.01)^{*}$ \\
\hline \multicolumn{5}{|c|}{ Mean graminoid height } \\
\hline-- & -- & $-0.08(0.17)$ & $0.12(0.03)^{*}$ & $0.48(<0.01)^{*}$ \\
\hline \multicolumn{5}{|c|}{ Standard deviation, water depth } \\
\hline-- & -- & -- & $0.53(<0.01)^{*}$ & $0.17(<0.01)^{*}$ \\
\hline \multicolumn{5}{|c|}{ Standard deviation, litter depth } \\
\hline-- & -- & -- & -- & $0.29(<0.01)^{*}$ \\
\hline
\end{tabular}


Table 3. Results of analysis of variance for habitat and environmental variables on study blocks in C3 and Marsh Creek study areas, Seney National Wildlife Refuge, Michigan, 2006-10.

$[p$, probability; *, significant at $\alpha=0.05]$

\begin{tabular}{|c|c|c|c|c|}
\hline Source of variation & $\begin{array}{c}\text { Numerator degrees } \\
\text { of freedom }\end{array}$ & $\begin{array}{c}\text { Denominator degrees } \\
\text { of freedom }\end{array}$ & F-statistic & $p$-value \\
\hline \multicolumn{5}{|c|}{ Mean water depth } \\
\hline Treatment & 3 & 9 & 1.13 & 0.39 \\
\hline Transect & 4 & 36 & 0.34 & 0.85 \\
\hline Treatment $\times$ transect & 12 & 36 & 0.25 & 0.99 \\
\hline Year & 4 & 180 & 82.80 & $<0.01^{*}$ \\
\hline Year $\times$ treatment & 12 & 180 & 6.30 & $<0.01^{*}$ \\
\hline Year $\times$ transect & 16 & 180 & 0.30 & 0.99 \\
\hline Year $\times$ treatment $\times$ transect & 48 & 180 & 0.16 & 0.99 \\
\hline \multicolumn{5}{|c|}{ Standard deviation, water depth } \\
\hline Treatment & 3 & 9 & 0.83 & 0.51 \\
\hline Transect & 4 & 36 & 0.66 & 0.63 \\
\hline Treatment $\times$ transect & 12 & 36 & 0.22 & 0.99 \\
\hline Year & 4 & 180 & 196.10 & $<0.01 *$ \\
\hline Year $\times$ treatment & 12 & 180 & 5.93 & $<0.01 *$ \\
\hline Year $\times$ transect & 16 & 180 & 0.39 & 0.98 \\
\hline Year $\times$ treatment $\times$ transect & 48 & 180 & 0.19 & 0.99 \\
\hline \multicolumn{5}{|c|}{ Mean litter depth } \\
\hline Treatment & 3 & 9 & 13.02 & $<0.01 *$ \\
\hline Transect & 4 & 36 & 0.14 & 0.97 \\
\hline Treatment $\times$ transect & 12 & 36 & 0.30 & 0.98 \\
\hline Year & 4 & 180 & 80.59 & $<0.01^{*}$ \\
\hline Year $\times$ treatment & 12 & 180 & 21.54 & $<0.01 *$ \\
\hline Year $\times$ transect & 16 & 180 & 0.41 & 0.98 \\
\hline Year $\times$ treatment $\times$ transect & 48 & 180 & 0.42 & 0.99 \\
\hline \multicolumn{5}{|c|}{ Standard deviation, litter depth } \\
\hline Treatment & 3 & 9 & 5.92 & $0.02 *$ \\
\hline Transect & 4 & 36 & 0.92 & 0.46 \\
\hline Treatment $\times$ transect & 12 & 36 & 0.18 & 0.99 \\
\hline Year & 4 & 180 & 160.84 & $<0.01^{*}$ \\
\hline Year $\times$ treatment & 12 & 180 & 5.50 & $<0.01^{*}$ \\
\hline Year $\times$ transect & 16 & 180 & 0.68 & 0.81 \\
\hline Year $\times$ treatment $\times$ transect & 48 & 180 & 0.37 & 0.99 \\
\hline \multicolumn{5}{|c|}{ Mean graminoid height } \\
\hline Treatment & 3 & 9 & 9.83 & $<0.01 *$ \\
\hline Transect & 4 & 36 & 0.53 & 0.72 \\
\hline Treatment $\times$ transect & 12 & 36 & 0.49 & 0.91 \\
\hline Year & 4 & 180 & 85.28 & $<0.01^{*}$ \\
\hline Year $\times$ treatment & 12 & 180 & 9.41 & $<0.01^{*}$ \\
\hline Year $\times$ transect & 16 & 180 & 0.85 & 0.63 \\
\hline Year $\times$ treatment $\times$ transect & 48 & 180 & 0.86 & 0.72 \\
\hline \multicolumn{5}{|c|}{ Standard deviation, graminoid height } \\
\hline Treatment & 3 & 9 & 5.97 & $0.02 *$ \\
\hline Transect & 4 & 36 & 1.57 & 0.20 \\
\hline Treatment $\times$ transect & 12 & 36 & 1.40 & 0.21 \\
\hline Year & 4 & 180 & 29.06 & $<0.01^{*}$ \\
\hline Year $\times$ treatment & 12 & 180 & 14.69 & $<0.01 *$ \\
\hline Year $\times$ transect & 16 & 180 & 0.67 & 0.82 \\
\hline Year $\times$ treatment $\times$ transect & 48 & 180 & 0.72 & 0.91 \\
\hline
\end{tabular}


In MC-2, mean water depth in summer increased from $0 \mathrm{~cm}$ in 2006 and 2007 to $>7 \mathrm{~cm}$ in 2008-10 and was markedly higher during 2008-10 than in other experimental blocks.

In C3, mean and variability of litter depth did not differ between control and burn blocks within each year, although mean litter depths were somewhat lower in spring-burned blocks in 2008 (fig. 9). In Marsh Creek, mean litter depth did not differ between control and burn blocks in 2006 but was 43 percent higher in control blocks in 2007. Litter depth in control blocks remained higher than in the burn blocks in the years after burning; by 2010, litter depth was 66 percent higher than 2008 levels in both treatments. Both Marsh Creek treatments had greater litter depths by 2010 than recorded in 2007. Litter-depth variability was $47-51$ percent lower in summer-burned blocks in the first 2 years after burning than in control blocks $(2008,1.81 \pm 0.49$ versus $3.45 \pm 0.31 ; 2009$,
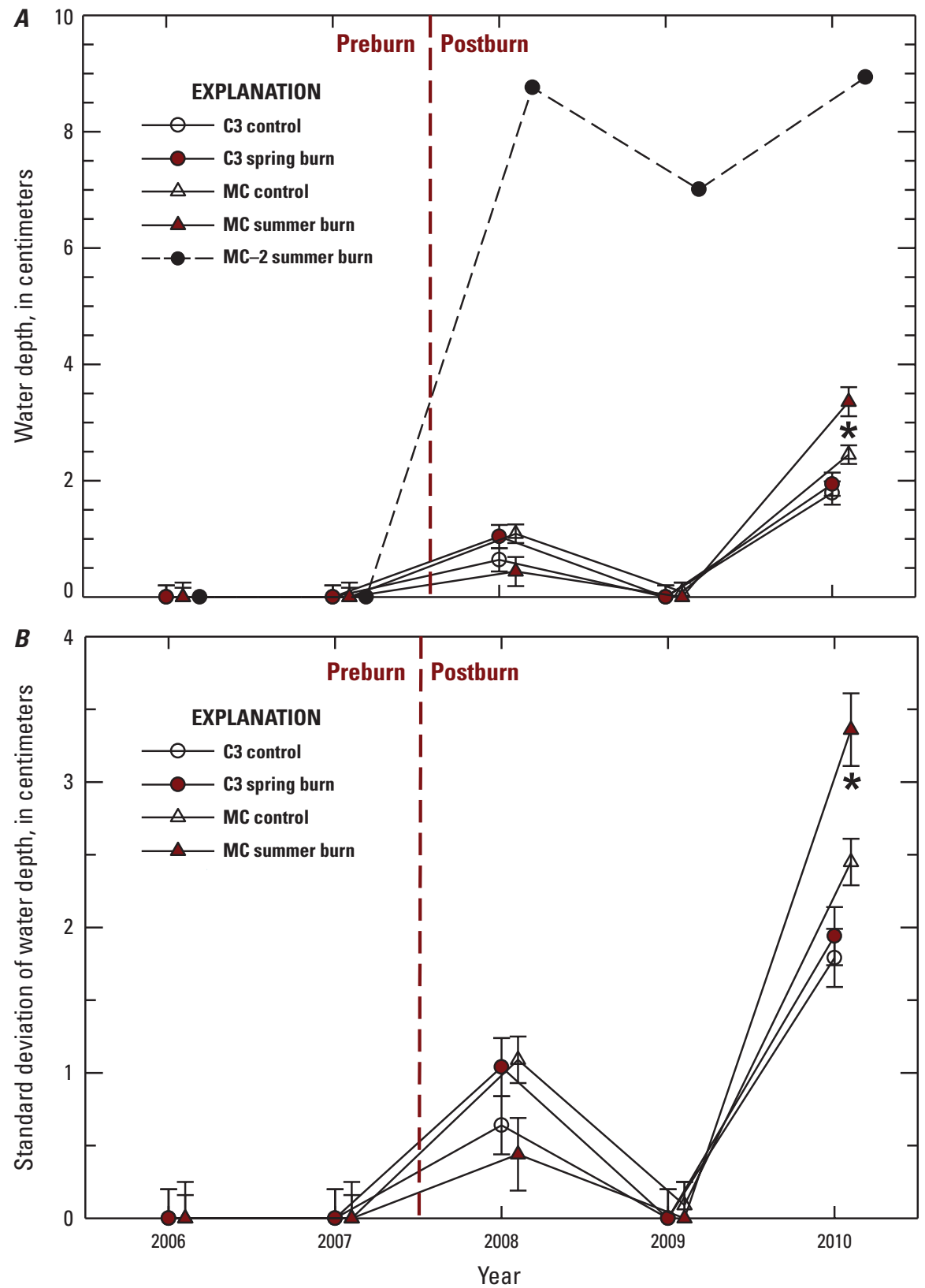

Figure 8. Summer water depths in control and burn blocks in C3 and Marsh Creek (MC) blocks, 2006-10, at Seney National Wildlife Refuge, Michigan. $A$, Least-squares means (standard error) of water depth across years; $B$, standard deviation (standard error) of water depths across years. Asterisks indicate significant difference (probability $<0.05$ ) between burn and control blocks within an area and year. 
$2.22 \pm 0.49$ versus $4.51 \pm 0.31$ ) but similar thereafter; differences were significant only in 2009. Mean and variability of litter depths in all four treatments indicated broad similarities across years, generally decreasing to 2008 then increasing again. In MC 2, litter was entirely removed by the July 2007 burn, remained minimal $(0.12 \mathrm{~cm})$ in 2008 , and then increased to $17.0 \mathrm{~cm}$ by 2010 .
Trends in graminoid heights across the years were generally similar in all treatments except the summer-burned blocks in Marsh Creek. No differences were detected in mean or variability of graminoid heights between control and springburned blocks in $\mathrm{C} 3$ within any of the 5 years but trended lower in posttreatment years (fig. 10). In Marsh Creek, mean graminoid heights did not differ between treatments in the pretreatment years $(2006,2007)$, but they were 84 percent
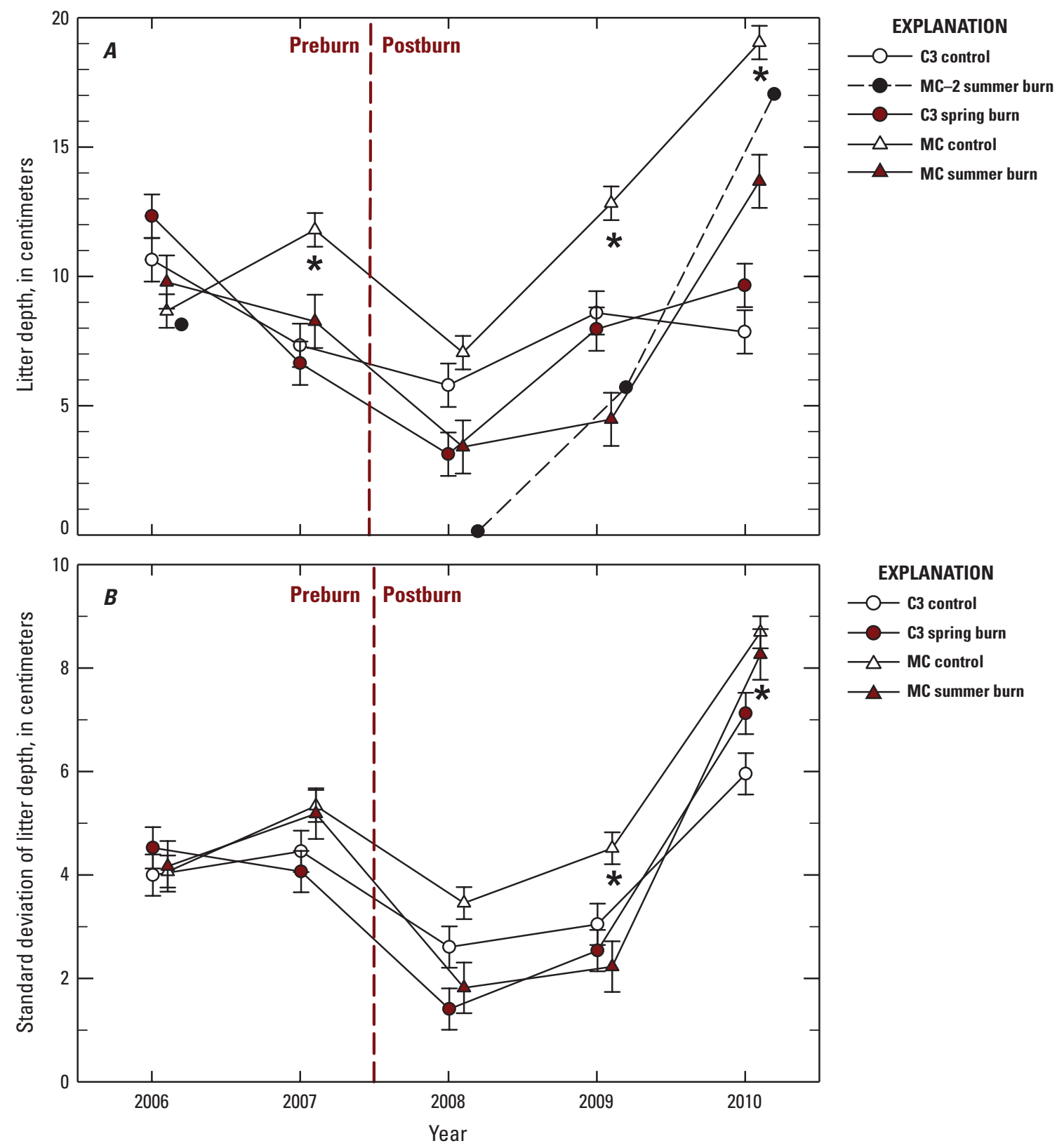

Figure 9. Litter depths in control and burn blocks in C3 and Marsh Creek (MC) blocks, 2006-10, at Seney National Wildlife Refuge, Michigan. $A$, Least-squares means (standard error) of water depths across years; $B$, Standard deviation (standard error) of water depths across years. C3 was burned in May 2007 and Marsh Creek in July 2007. The MC-2 block was burned in July 2007. Asterisks indicate significant difference (probability $<0.05$ ) between burn and control blocks within an area and year. 
lower in summer-burned blocks than in control blocks in 2008. They remained 54 percent lower in 2009 but were not significantly different that year. No treatment differences were detected in 2010, 2 years after the burn. Variability in graminoid heights showed similar trends in Marsh Creek, with 61 percent lower variability in summer-burned blocks in 2008 and 26 percent lower variability in 2009 but no significant difference between treatments in 2009 or 2010 . The marked decline in graminoid height and variability in summer-burned blocks between 2007 and 2008 reflects the short (3-week) period between burning and data collection and a combination of a patchy burn (some remaining graminoids) and rapid early regrowth. Graminoid height in $\mathrm{MC}-2$ fell to $0 \mathrm{~cm}$ after the summer burn in 2007 (a complete burn), remained 21-27 cm lower than the 2006 heights in the 2 years after burning, and was $11 \mathrm{~cm}$ lower 3 years after burning.

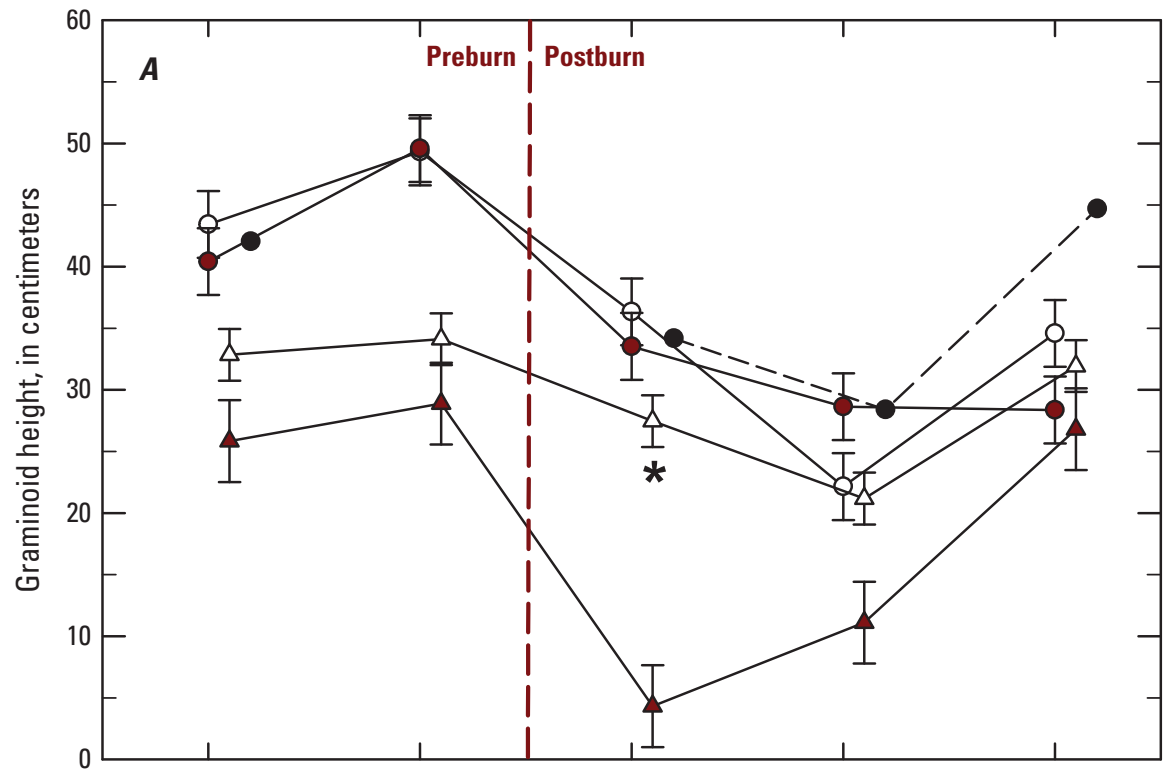

EXPLANATION
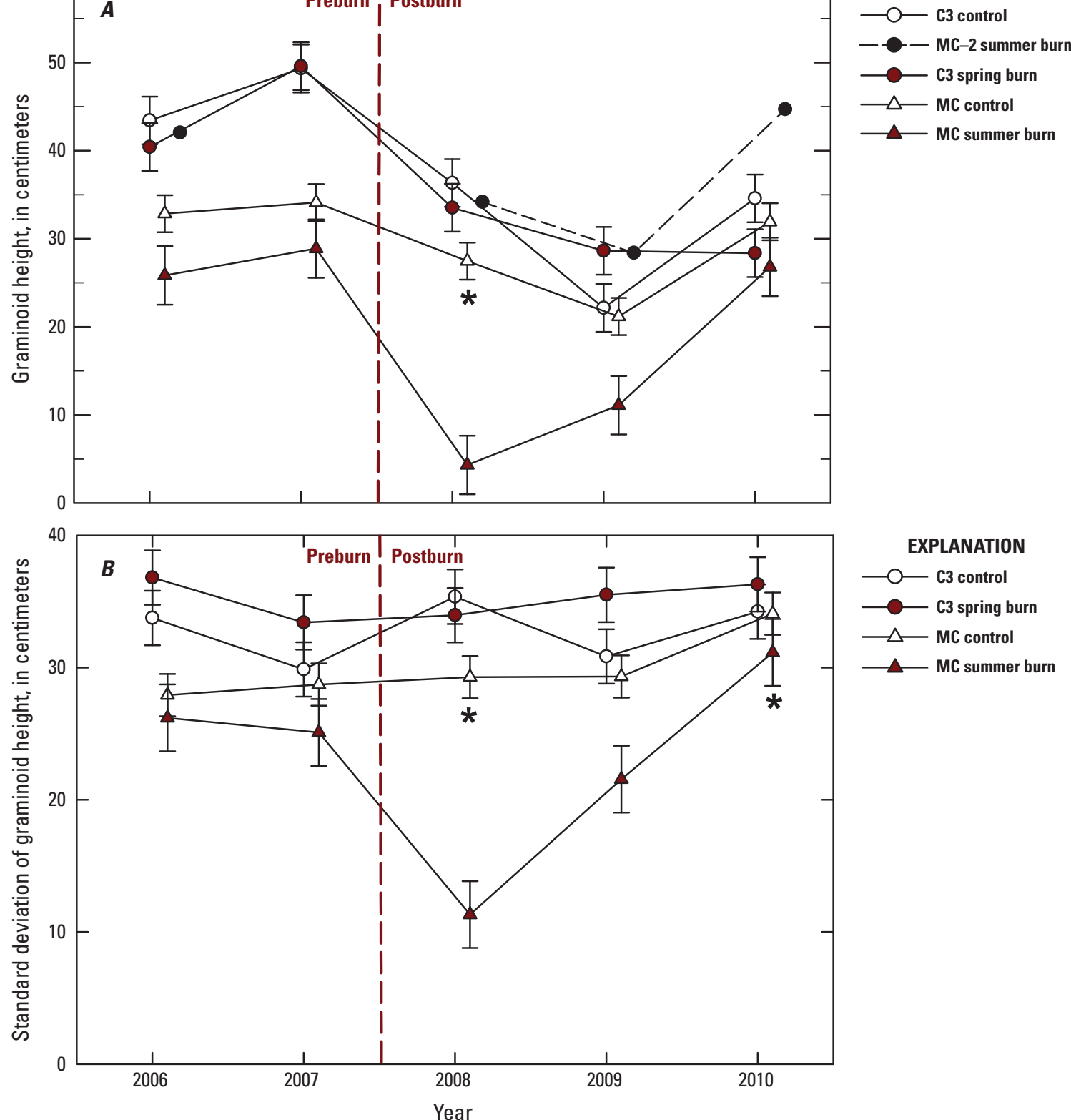

EXPLANATION

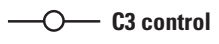

- C3 spring burn

$\triangle-M C$ control

MC summer burn

Figure 10. Graminoid height (mean and standard error) in control and burn blocks in C3 and Marsh Creek (MC) blocks, 2006-10, at Seney National Wildlife Refuge, Michigan. $A$, Least-squares means (standard error) of water depths across years; $B$, standard deviation (standard error) of water depths across years. C3 was burned in May 2007 and Marsh Creek in July 2007. The MC-2 block was burned in July 2007. Asterisks indicate significant difference (probability $<0.05$ ) between burn and control blocks within an area and year. 


\section{Plant Community}

We identified a total of 104 plant taxa (excluding bryophytes) on the 14 blocks over the 5 years (90 identified taxa in $\mathrm{C} 3$ and 81 in Marsh Creek; see glossary and appendix 1 for plant taxa scientific and common names). For combined areas, 38 percent of identified taxa were forbs; 25 percent were woody species; 21 percent were sedges, rushes, or cattail; 9 percent were grasses; and 7 percent were nonangiosperms (for example, ferns). Only one introduced species was detected (marsh thistle, Cirsium palustre); it was detected only in MC-7 sampling points but also was noted scattered throughout $\mathrm{C} 3$ outside of the experimental blocks in 2010 . Most species (57 percent) were obligate wetland hydrophytes, 35 percent were facultative wetland hydrophytes, 4 percent were facultative hydrophytes, 3 percent were facultative upland nonhydrophytes, and 1 percent was upland nonhydrophyte (Canada mayflower, Maianthemum canadense).

The plant communities of the two areas were generally similar, but some broad differences in taxa occurrence (appendix 3) are of note. C3 contained a greater diversity of woody taxa, whereas leatherleaf was detected almost entirely in Marsh Creek. Although we had difficulties in identifying some narrowed-leaved Carex to species in 2006 and 2007 (hence the combination into narrow-leaved sedge), speciesspecific results indicate fewseed sedge (C. oligosperma) was common in Marsh Creek and rarely detected in $\mathrm{C} 3$, whereas woollyfruit sedge (C. lasiocarpa) seemed to be present mainly in C3; only in 2010 was it identified in Marsh Creek. Another narrow-leaved sedge, inland sedge (C. interior), was equally common in both areas and was likely among the unidentified taxa in 2006, particularly as unidentified CAREX2. Among the more common species, creeping sedge $(C$. chordorrhiza), livid sedge (C. livida), bedstraws (Galium spp.), harlequin blueflag (Iris versicolor), bog goldenrod (Solidago uliginosa), and northern bog aster (Symphyotrichum boreale) were detected more often in Marsh Creek, whereas spike muhly (Muhlenbergia glomerata) was detected more frequently in $\mathrm{C} 3$. White beak-rush (Rhynchospora alba) was detected only in C3-1 and C3-2. Broadleaf cattail, a species of concern in some areas for its potential to develop into monotypic stands, was detected at low frequency and only in C3-3 and C3-4, near marsh (fig. 2).

\section{Species Richness and Diversity}

In 2007, the year before burn treatments were applied, species richness per block averaged 24.7 \pm 2.4 in C3 control plots, 26.0 \pm 2.4 in C3 burn plots, 25.6 \pm 2.4 in Marsh Creek control plots, and 31.0 \pm 3.0 in Marsh Creek burn plots (fig. 11A). Species richness in $\mathrm{C} 3$ control and burn blocks and in Marsh Creek control blocks was somewhat lower in 2009 than other years but generally recovered to or near pretreatment levels by 2010 . Significant year $\times$ treatment interaction (table 4) for species richness was largely due to annual changes in Marsh Creek. Species richness there declined from 2007 to 2008 in both control and summer-burned blocks by 19 and 65 percent, respectively. Not surprisingly, species richness differed significantly between treatments there in 2008, when data were collected just a few weeks after burning. Species richness in MC-2 followed a similar pattern to other blocks (fig. 11A).

Similarly, the Shannon diversity index $(H)$ differed marginally between burn and control treatments only in Marsh Creek in 2008 (year $\times$ treatment interaction; table 4, fig. 11B). After one full growing season after the 2008 burn at Marsh Creek, the diversity index in burned blocks had recovered to levels similar to those of 2007 in the burned blocks. The diversity index in $\mathrm{C} 3$ remained relatively constant across years.

\section{Percent Cover by Taxa-Year and Treatment Effects}

We examined data for effects of treatment, year, and year $\times$ treatment interactions for percent open and the 28 most commonly detected taxa. Of those taxa, 2 showed no effects of treatment, year, or their interaction, whereas 16 showed no differences between burn and control blocks within an area and year (table 4). We describe results by plant forms (sedges/ rushes, grasses, forbs, moss, woody plants) and for open area.

We detected a year $\times$ treatment interaction for percent cover of open area (OPEN; table 4). Open area in burned treatments was 300 percent higher than in control treatments in Marsh Creek in 2008 but did not differ for other years there; no treatment differences were detected in C3 (fig. 12). Burn and control blocks in both areas showed a gradual upward trend in open area from 0 percent in 2006 to 21-33 percent in 2010. Open area in MC-2 changed little after recovering from the 2007 summer burn. Similar to other blocks, percent open in MC-2 was 0 in 2006 and higher in postburn years.

Year $\times$ treatment interactions were detected for six of the eight sedges and rushes (table 4). Percent cover of the narrow-leaved sedges (CAREX, fig. 13A) was highest in $\mathrm{C} 3$ but declined 44 and 49 percent in $\mathrm{C} 3$ control and burn blocks, respectively, between 2007 and 2010. In 2009, percent cover of narrow-leaved sedges in $\mathrm{C} 3$ was 59 percent higher in spring-burned blocks than in control blocks. In Marsh Creek, narrow-leaved sedge cover values were consistently lower in summer-burned blocks than control blocks, but differences were significant only in 2008 and 2009, when cover was 67-68 percent lower on summer-burned blocks. Cover of creeping sedge (CARCHO, fig. 13B) also indicate year $\times$ treatment interactions and was particularly variable in Marsh Creek. Cover trended higher in 2008 in all but Marsh Creek summer-burn blocks; in C3, percent cover across years declined to or below 2006 levels by 2010. Livid sedge (CARLIV, fig. 13C), detected mainly in Marsh Creek, was rarely detected in 2006, but we detected no changes in percent cover across years or differences between burn and control blocks there. Its absence in 2006 may have been due to difficulties in sedge identification the first year. Buxbaum's sedge (Carex buxbaumii) was detected only in 2010 in Marsh 


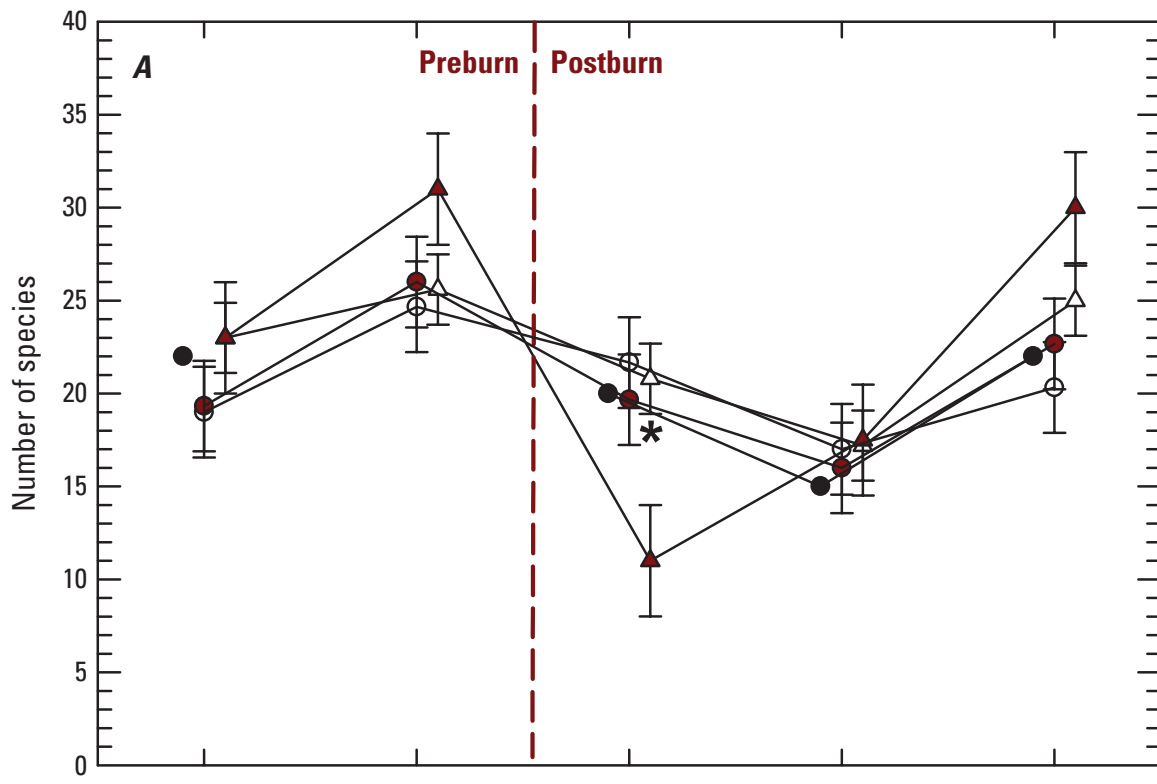

\section{EXPLANATION}
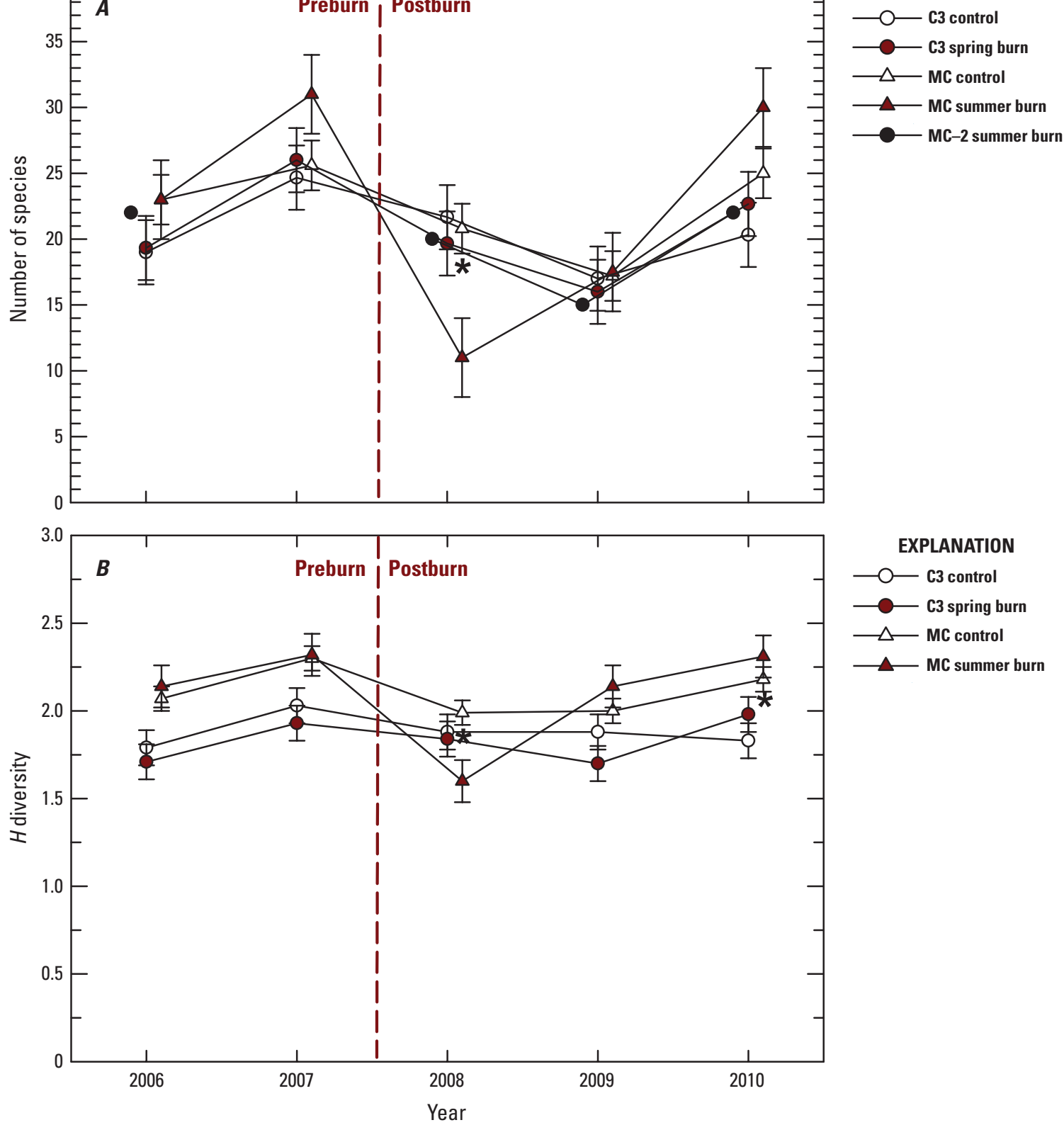

Figure 11. Measures of biological diversity detected in control and burn blocks in C3 and Marsh Creek study areas, 2006-10, at Seney National Wildlife Refuge, Michigan. $A$, Species richness; and $B$, Shannon diversity index $(H)$. No data were collected in $M C-2$ in 2007, the year it was burned. Whiskers indicate standard errors. Asterisks indicate significant difference (probability $<0.05$ ) between burn and control blocks within an area and year.

Creek, with little difference between burned and control blocks (CARBUX, fig. 13D); it was most abundant in MC-2 in 2010. Cover of cottongrasses (ERIOPH, fig. 14A) was highest in Marsh Creek in 2006, but in later years, few differences were detected in percent cover among years or between treatments except immediately after the summer burn in 2008 . By 2010 in Marsh Creek, three growing seasons later, its cover remained 76 percent below the 2007 levels in summerburned blocks and 68 percent below in control blocks. Elliptic spikerush (Eleocharis elliptica; ELEELL, fig. 14B) was most common in $\mathrm{C} 3$ control blocks across all years, but its cover was highly variable within blocks. We detected only a year effect; in 2008, percent cover in all blocks declined to less than 5 percent but largely recovered to 2006-7 levels by 2010 . The steepest decline and recovery were detected in C3 control blocks. For the less common Robbins' spikerush (Eleocharis robbinsii; ELEROB, fig. 14C), percent cover was higher in Marsh Creek burn blocks than control blocks in 2006 and 
Table 4. Results of analysis of variance for species richness, species diversity index (Shannon diversity index, $H$ ), nonmetric dimensional scaling (NMS) scores on 3 axes, and percent cover of open, moss, and 27 plant taxa on study blocks in C3 and Marsh Creek study areas, Seney National Wildlife Refuge, Michigan, 2006-10.

[See appendix 1 for taxa codes. $p$, probability; *, significant at $\alpha=0.05$ ]

\begin{tabular}{|c|c|c|c|}
\hline \multirow{2}{*}{ Variable } & \multicolumn{3}{|c|}{$F$-statistic ( $p$-value) } \\
\hline & Treatment & Year & Year $\times$ treatment \\
\hline Species richness & $0.24(0.87)$ & $39.98(<0.01)^{*}$ & $5.72(<0.01)^{*}$ \\
\hline Shannon diversity index $(H)$ & $4.42(0.04)^{*}$ & $12.45(<0.01)^{*}$ & $3.26(<0.01)^{*}$ \\
\hline NMS_-Axis 1 & $9.39(<0.01)^{*}$ & $13.52(<0.01)^{*}$ & $5.62(<0.01)^{*}$ \\
\hline NMS-Axis 2 & $18.59(<0.01)^{*}$ & $36.66(<0.01)^{*}$ & $527(<0.01)^{*}$ \\
\hline NMS-Axis 3 & $2.49(0.13)$ & $51.19(<0.01)^{*}$ & $3.79(<0.01)^{*}$ \\
\hline Open & $5.91(<0.01)^{*}$ & $67.03(<0.01)^{*}$ & $9.16(<0.01)^{*}$ \\
\hline Moss & $3.32(0.07)$ & $17.00(<0.01)^{*}$ & $1.46(0.19)$ \\
\hline ANDGLA & $1.78(0.22)$ & $2.79(0.04)^{*}$ & $1.14(0.36)$ \\
\hline BETPUM & $1.40(0.30)$ & $11.07(<0.01)^{*}$ & $1.56(0.15)$ \\
\hline CALCANAG $^{1}$ & $0.53(0.68)$ & $4.01(<0.01)^{*}$ & $1.78(0.09)$ \\
\hline CAMAPA & $1.49(0.28)$ & $14.35(<0.01)^{*}$ & $2.66(0.01)^{*}$ \\
\hline CARBUX & $18.75(<0.01)^{*}$ & $52.53(<0.01)^{*}$ & $18.75(<0.01)^{*}$ \\
\hline CARCHO & $0.93(0.46)$ & $5.89(<0.01)^{*}$ & $1.99(0.05)^{*}$ \\
\hline CAREX & $15.54(<0.01)^{*}$ & $25.36(<0.01)^{*}$ & $2.83(<0.01)^{*}$ \\
\hline CARLIV & $7.74(<0.01)^{*}$ & $19.89(<0.01)^{*}$ & $3.02(<0.01)^{*}$ \\
\hline CHACAL & $82.28(<0.01)^{*}$ & $14.76(<0.01)^{*}$ & $7.63(<0.01)^{*}$ \\
\hline ELEELL & $2.09(0.17)$ & $20.28(<0.01)^{*}$ & $1.56(0.15)$ \\
\hline ELEROB & $5.54(0.02)^{*}$ & $11.42(<0.01)^{*}$ & $4.26(<0.01)^{*}$ \\
\hline ERIOPH & $1.02(0.43)$ & $19.17(<0.01)^{*}$ & $2.98(<0.01)^{*}$ \\
\hline GALIUM & $12.11(<0.01)^{*}$ & $5.34(<0.01)^{*}$ & $2.37(0.02)^{*}$ \\
\hline HYPKAL & $1.43(0.30)$ & $3.13(0.03)^{*}$ & $1.29(0.27)$ \\
\hline IRIVER & $1.96(0.19)$ & $1.70(0.17)$ & $2.41(0.02)^{*}$ \\
\hline LYSTER & $4.73(0.03)^{*}$ & $8.44(<0.01)^{*}$ & $1.31(0.26)$ \\
\hline MUHGLO & $18.00(<0.01)^{*}$ & $0.88(0.48)$ & $0.74(0.70)$ \\
\hline POTFRU & $0.18(0.91)$ & $11.52(<0.01)^{*}$ & $1.89(0.07)$ \\
\hline RHYALB & $0.88(0.49)$ & $2.03(0.11)$ & $0.86(0.59)$ \\
\hline RUBUS & $0.23(0.88)$ & $4.73(<0.01)^{*}$ & $1.16(0.35)$ \\
\hline SALIX & $8.13(<0.01)^{*}$ & $17.69(<0.01)^{*}$ & $1.56(0.15)$ \\
\hline SOLULI & $1.22(0.36)$ & $5.74(<0.01)^{*}$ & $2.62(0.01)^{*}$ \\
\hline SYMBOR & $1.65(0.25)$ & $124.89(<0.01)^{*}$ & $2.20(0.03)^{*}$ \\
\hline SYMPUN & $0.27(0.84)$ & $54.09(<0.01)^{*}$ & $5.90(<0.01 *)$ \\
\hline TRIFRA & $0.76(0.54)$ & $9.57(<0.01)^{*}$ & $0.27(0.99)$ \\
\hline VACCINS & $2.20(0.16)$ & $1.74(0.16)$ & $0.95(0.51)$ \\
\hline VIOLAS & $1.29(0.34)$ & $69.85(<0.01)^{*}$ & $1.30(0.26)$ \\
\hline
\end{tabular}

'PROC GLIMMIX would not converge using beta distribution; assumed distribution was normal. 


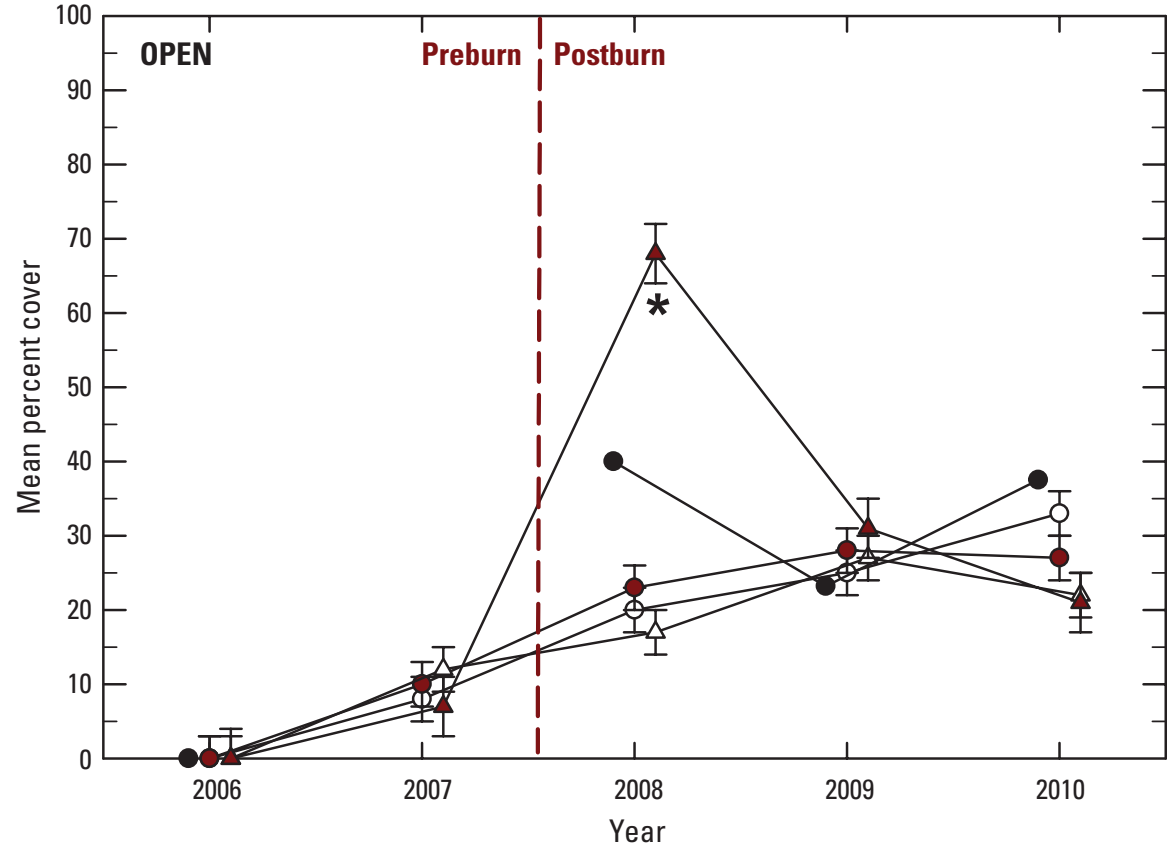

EXPLANATION

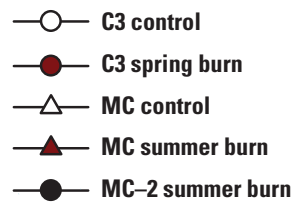

Figure 12. Percent open area (leastsquares means, standard error) affected by year $\times$ treatment interactions in control and burn blocks in C3 and Marsh Creek (MC) blocks, 2006-10, at Seney National Wildlife Refuge, Michigan. Whiskers indicate standard errors. Asterisks indicate significant difference (probability $<0.05$ ) between burn and control blocks within an area and year.
2007, but its cover declined to 0 after the summer burn and remained at low levels in all blocks through 2010. In contrast to other sedges and rushes, we detected no year, treatment, or year $\times$ treatment interactions for white beak-rush (RHYABL, fig. 14D), which was detected only in C3-1 (detected at 75 percent of sample points) and C3-2 (14 percent of sample points); it was not detected in those blocks in 2010.

The two grasses examined differed in effects. Percent cover of bluejoint (CALCANAG) varied among years, with highest percent cover detected in MC-2 in 2006 (table 4, fig. 15A); its cover was lowest in 2008 after the summer burn. Spike muhly (MUHGLO, fig. 15B) was affected by treatment because of its greater abundance in C3 (table 4).

Among forbs, we detected year $\times$ treatment interactions for six taxa (table 4). Cover of marsh bellflower (Campanula aparinoides; CAMAPA, fig. 16A) trended upward from 2006 to 2008 in all but Marsh Creek burn blocks, then declined to 2006 levels by 2010. In C3, its cover was consistently higher on control than burn blocks, but differences were significant only in 2007. In Marsh Creek, its cover also tended to be higher on control than burn blocks across years, but differences were significant only in 2008. Cover in summer-burned blocks was 96 percent lower in control blocks that year, but by 2010 , percent cover was similar between burn and control blocks. In MC-2, marsh bellflower cover was highest the year after burning but quickly declined to below preburn levels. Bedstraw (GALIUM; fig. 16B) cover was highest in Marsh Creek before burning; cover in burn blocks there did not recover to preburn levels by 2010 . Harlequin blueflag (IRIVER, fig. 16C) was somewhat more common in Marsh Creek control blocks through 2008 but declined to levels similar to other blocks in 2009 and 2010. It was most abundant in $\mathrm{MC}-2$ but also showed a decline in postburn years. Cover of bog goldenrod (SOLULI, fig. 16D) tended to be higher in Marsh Creek than in $\mathrm{C} 3$ before 2008 but declined thereafter to equivalent levels. We also detected year $\times$ treatment interactions for percent cover of the two asters examined, but the species showed different responses across years. Cover of northern bog aster (SYMBOR, fig. 16E) was higher in the preburn years, fell to near zero in 2008 and 2009 in all blocks, and remained 73-94 percent below 2007 levels by 2010. By 2010, its cover in summer-burned blocks in Marsh Creek was higher than in control blocks, but differences were not significant. In contrast, cover of purplestem aster (Symphyotrichum puniceum; SYMPUN, fig. 16F) in Marsh Creek spiked one growing season after the summer burn (2009) before largely disappearing in 2010 in all blocks. In C3, it was most abundant in 2007 and 2009 and was higher in burn blocks than in control blocks in 2007.

Of the forb taxa, four were affected only by year. Cover of Kalm's St. Johnswort (Hypericum kalmianum; HYPKAL, fig. 17A), detected primarily in Marsh Creek, was somewhat lower in 2008 and 2009 than 2007. The high variability in the cover of shrubby cinquefoil (Potentilla fruticosa, POTFRU, fig. 17B) limited any ability to detect differences among treatments. Cover of Fraser's marsh St. Johnswort (Triadenum fraseri; TRIFRA, fig. 17C) declined in both areas after 2007. Few violets (Viola spp.; $<0.1$ percent cover) were detected in 2006 and 2009, but cover was higher in most treatments in 2007 and 2010, with similar cover in spring- and summerburned blocks (VIOLA, fig. 17D). Within areas and years, violet cover was somewhat higher in C3 burn blocks in 2007 and significantly higher in spring-burned blocks in 2008 and 2010 . 

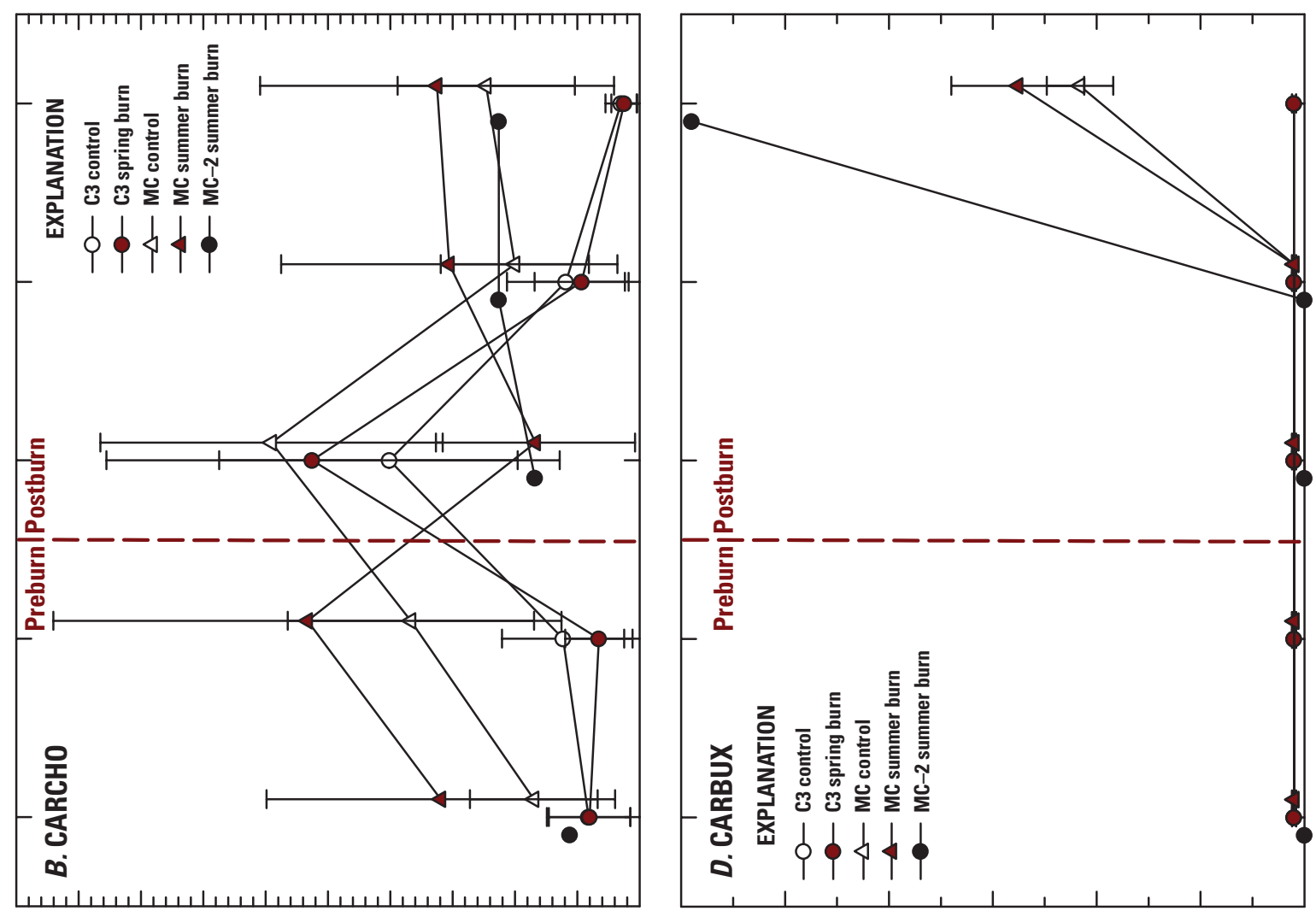

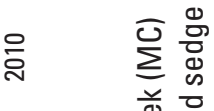

힐 을

ज

勿㠇

웅

ᄁᄁ

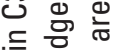

要

㐫

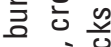

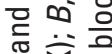

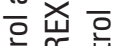

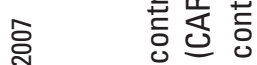

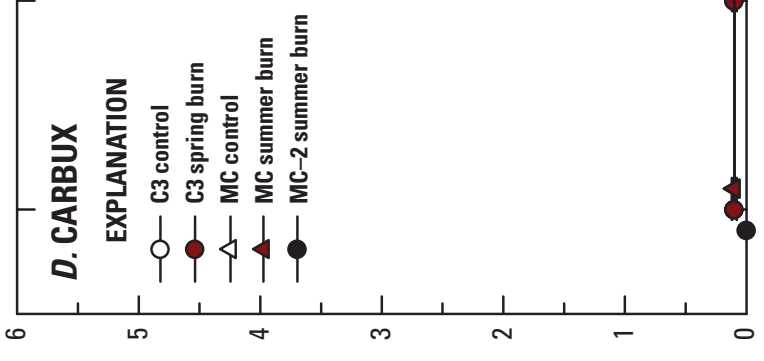

$\cong \stackrel{0}{\circ}$

¿

要

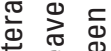

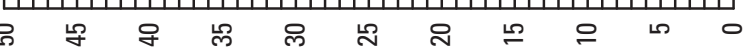
เәлоэ ұиәэљәd uеәW

เәлоэ ұนวэәd иеәW
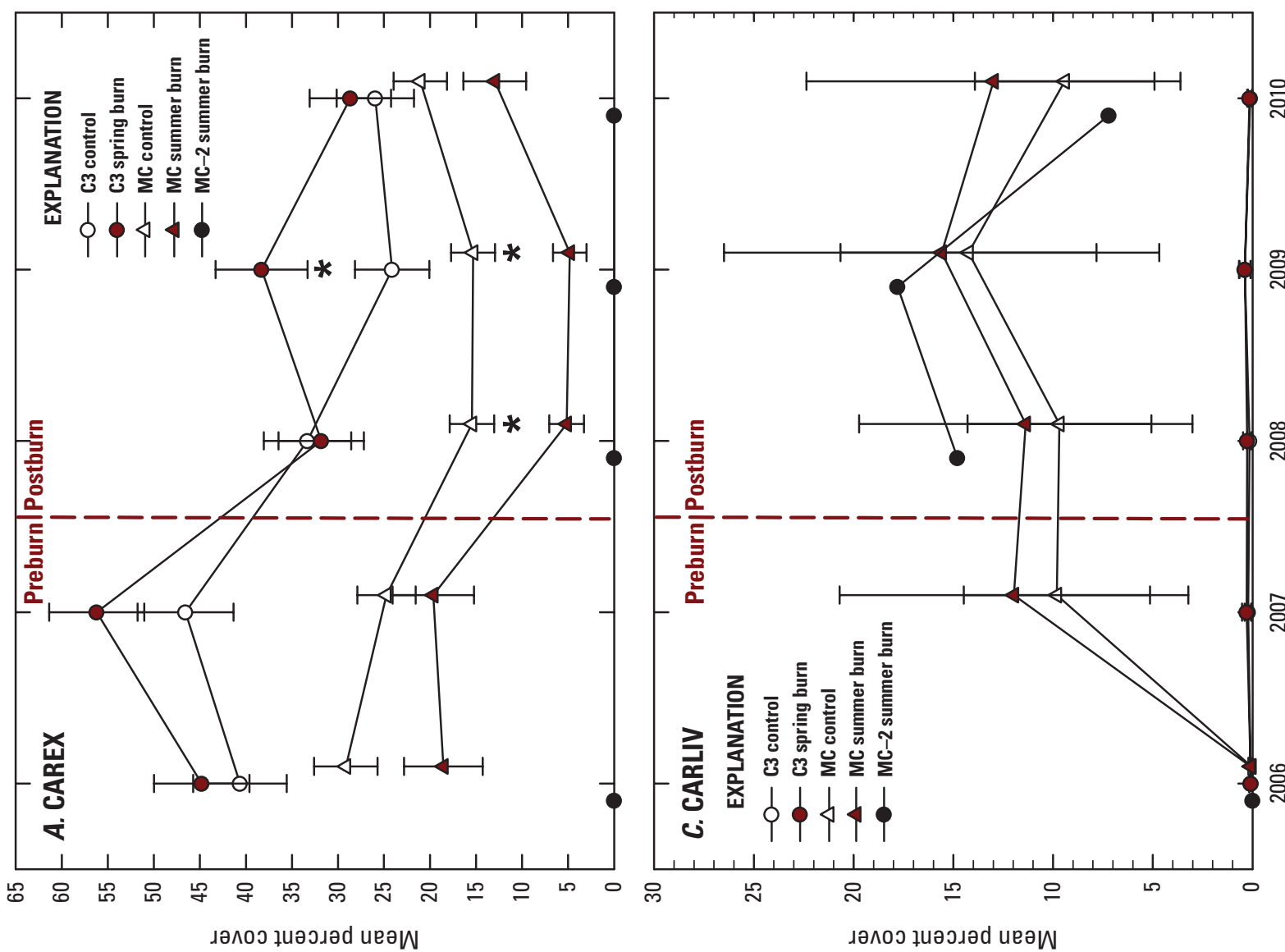

덩 d

至桴路

¿

$\times$ 흔

齐 产

$\stackrel{2}{2}$

츠응 인

모들

式

त 정

흥 응

这 䒕

힌 兽

至交

क टं

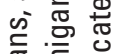

엉 듬

$\sum$

\& क

즌 익 는

它要

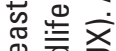

응 윽

क \年

융 ত

क 응

范䓠 总

ఫे ब

ठํ बे त

¿ क i

ฮู స

힝

- 10

๓

인 竞

은 응 은 

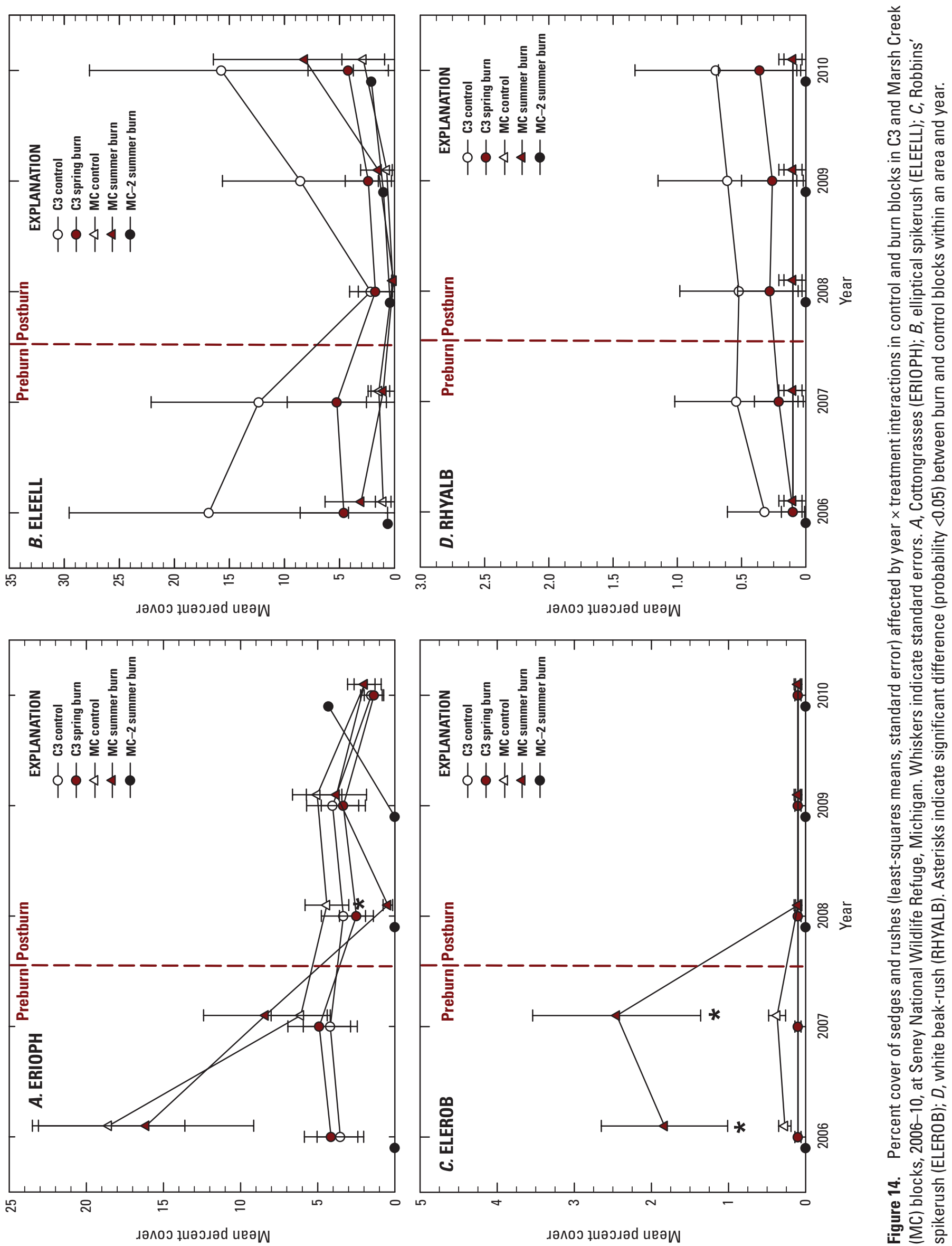
Figure 15. Percent cover of grasses (leastsquares means, standard error) affected by separate year and treatment effects in control and burn blocks in C3 and Marsh Creek (MC) blocks, 2006-10, at Seney National Wildlife Refuge, Michigan. Whiskers indicate standard errors. A, Bluejoint (CALCANAG); $B$, spike muhly (MUHGLO). Asterisks indicate significant difference (probability $<0.05$ ) between burn and control blocks within an area and year.
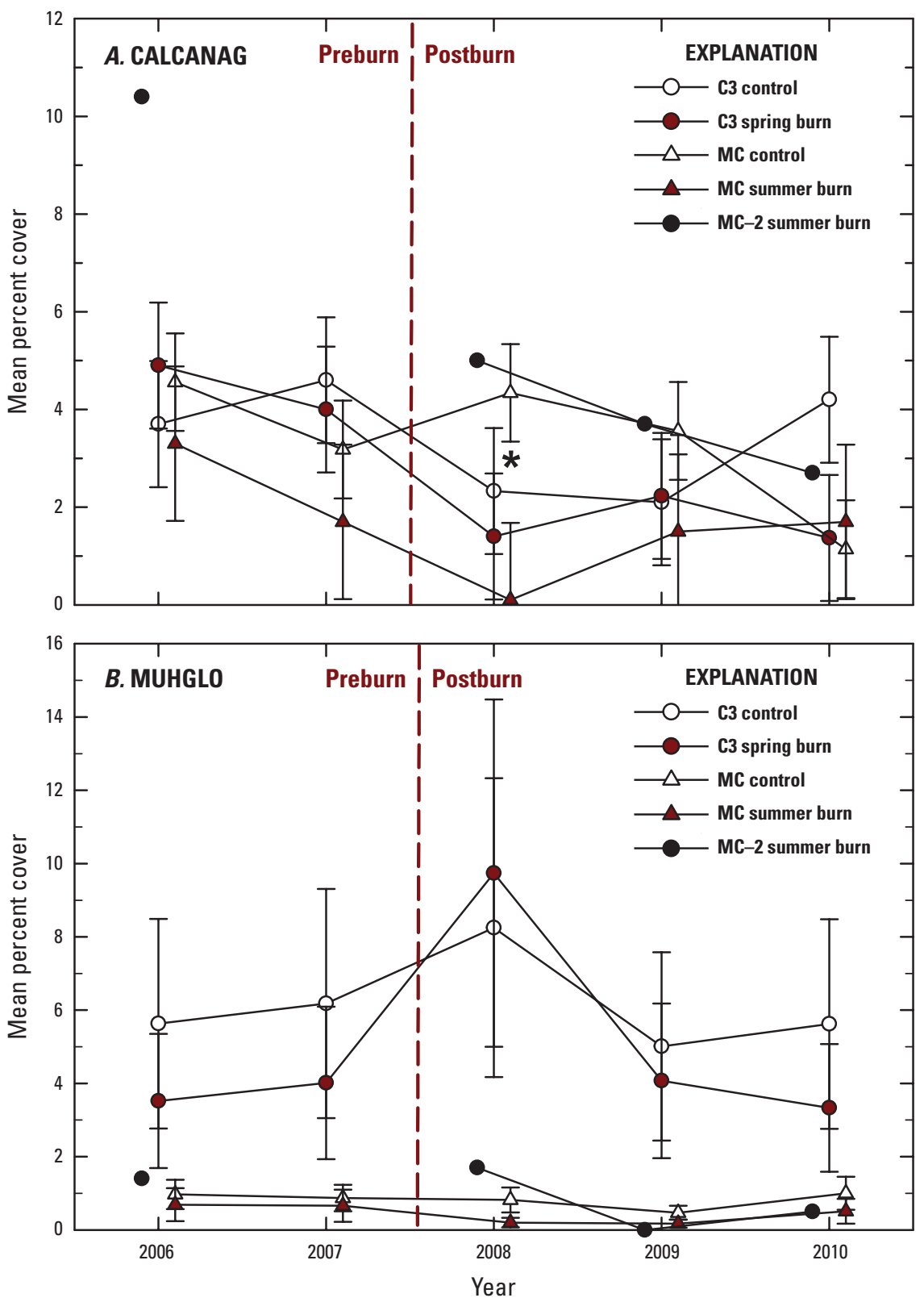

We detected separate year and treatment effects for earth loosestrife (Lysimachia terrestris; table 4; LYSTER, fig. 18), indicating a mixed response to burning. Its cover increased from near 0 in 2006 to peak levels in 2008 in all but Marsh Creek burn blocks, then declined to near 0 in all blocks by 2010. It was most abundant in MC-2 during 2008-10 but also declined there after 2008. In C3, its cover was higher in control than burn blocks the year before spring burns but not thereafter, whereas in Marsh Creek, cover was higher in control than in summer-burned blocks in 2008 and 2009.

Percent cover of moss indicated a year $\times$ treatment interaction (table 4; MOSS, fig. 19). Moss cover ranged from 4 to 13 percent in 2006, 2007, and 2009. In C3, moss cover was 314 percent higher in spring-burned blocks in 2008 and 164 percent higher in 2010 than in control blocks. Moss cover in Marsh Creek in 2010 also increased from earlier levels on both burned and control blocks; its cover tended to be higher on control blocks than burned blocks during 2008-10, but differences were not significant. Often, when the sample segment seemed devoid of vascular plants, moss was detected growing on decaying litter or peat.

A year $\times$ treatment interaction affected the percent cover of leatherleaf (table 4). Leatherleaf was rarely detected in C3 or MC-2 but was abundant elsewhere in Marsh Creek (CHACAL, fig. 20). Leatherleaf cover was consistently higher in blocks assigned to summer burns than in the control blocks, except after burning in 2008. Leatherleaf was 116 percent higher in burn blocks in 2007, fell 93 percent in burned blocks in 2008, but recovered to near preburn levels by 2010 . 

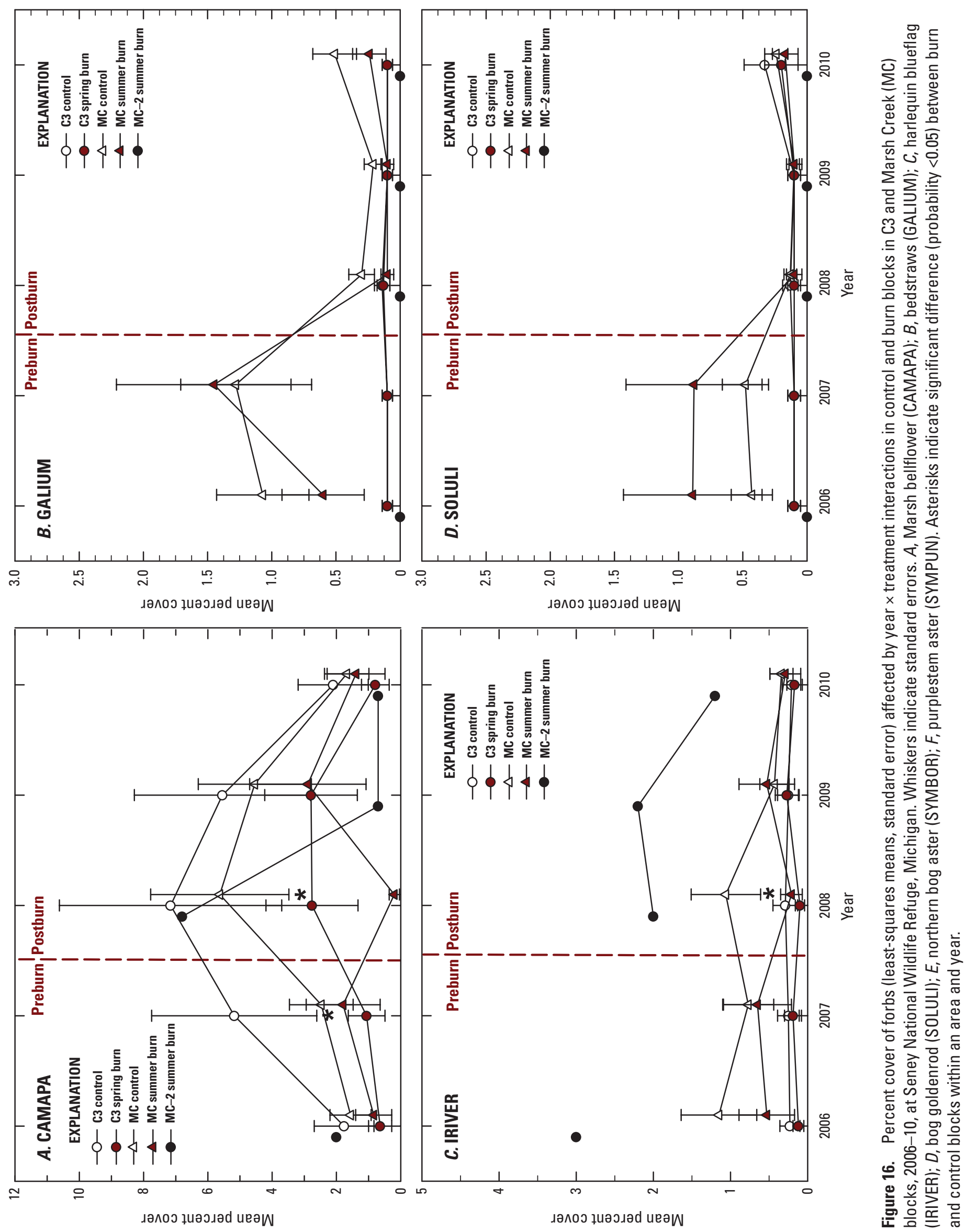
Figure 16. Percent cover of forbs (leastsquares means, standard error) affected by year $\times$ treatment interactions in control and burn blocks in C3 and Marsh Creek (MC) blocks, 2006-10, at Seney National Wildlife Refuge, Michigan. Whiskers indicate standard errors. $A$, Marsh bellflower (CAMAPA); $B$, bedstraws (GALIUM); $C$, harlequin blueflag (IRIVER); $D$, bog goldenrod (SOLULI); $E$, northern bog aster (SYMBOR); F, purplestem aster (SYMPUN). Asterisks indicate significant difference (probability $<0.05$ ) between burn and control blocks within an area and year.-Continued
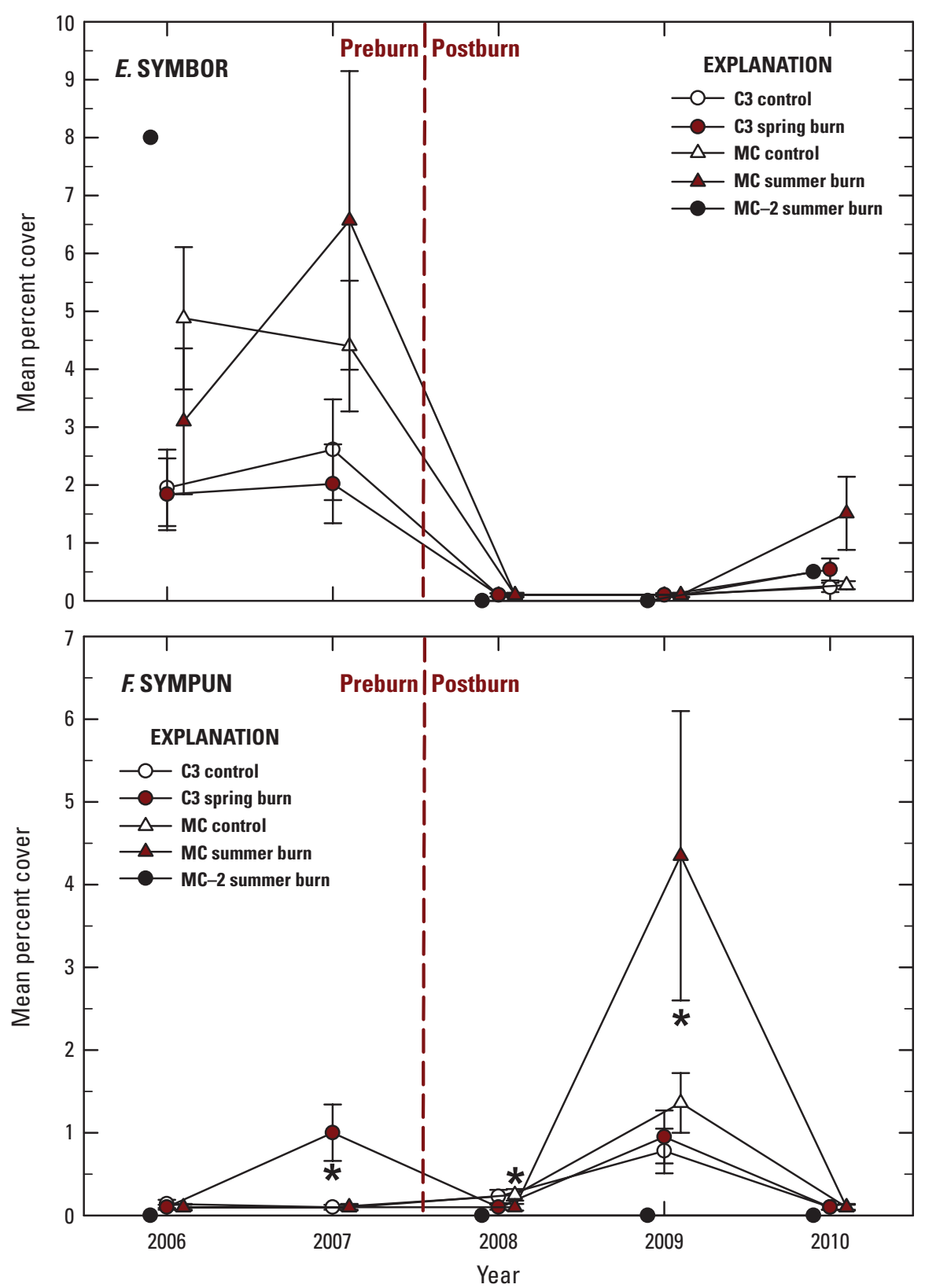

We detected no year $\times$ treatment interactions for other woody taxa (table 4). Percent cover of bog rosemary (Andromeda polifolia var. glaucophylla) (ANDGLA, fig. 21A), raspberries (Rubus spp.; RUBUS, fig. 21B), and bog birch (BETPUM, fig. 21C) were affected only by year, whereas willows (SALIX, fig. 21D) were affected by separate year and treatment interactions. Cover of bog birch was consistently higher in $\mathrm{C} 3$ burn blocks than in control blocks and significantly higher in 2007 and 2010. Willows were primarily detected in C3; cover there peaked in control blocks in 2007 and 2010, but cover did not differ between burned and control blocks within the area. Vaccinium (VACCIN, fig. 21E) was rarely found in Marsh Creek blocks and somewhat more abundant in $\mathrm{C} 3$. 

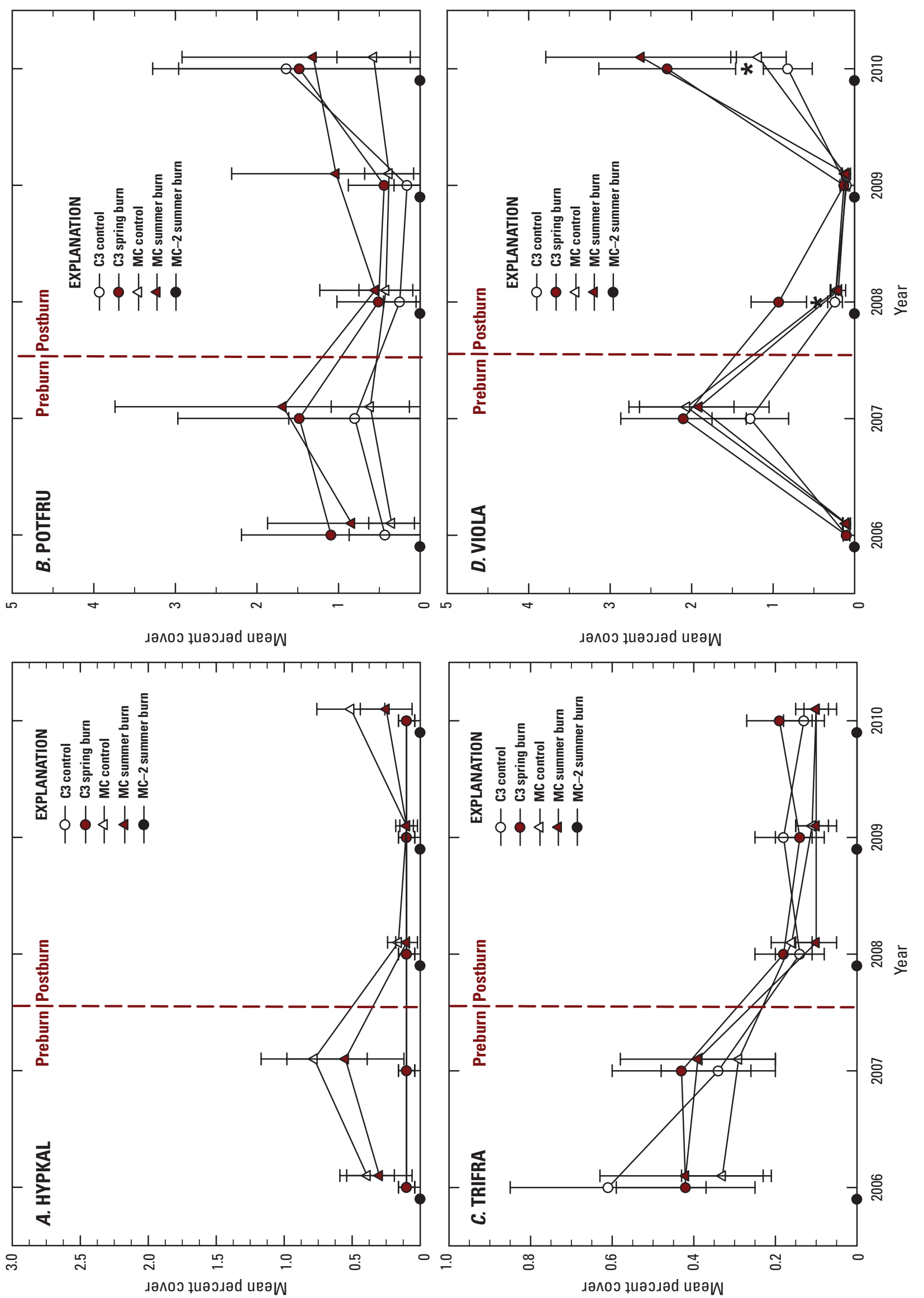

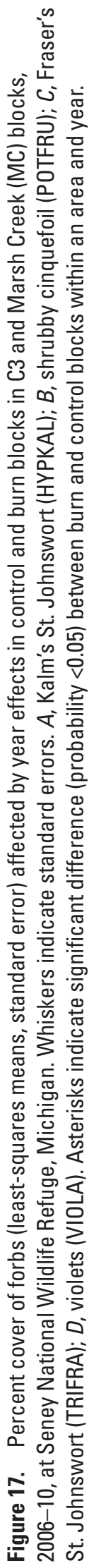


Figure 18. Percent cover of earth loosestrife (LYSTER) (least-squares means, standard error) affected by separate year and treatment effects in control and burn blocks in C3 and Marsh Creek (MC) blocks, 2006-10, at Seney National Wildlife Refuge, Michigan. Whiskers indicate standard errors. Asterisks indicate significant difference (probability $<0.05$ ) between burn and control blocks within an area and year.
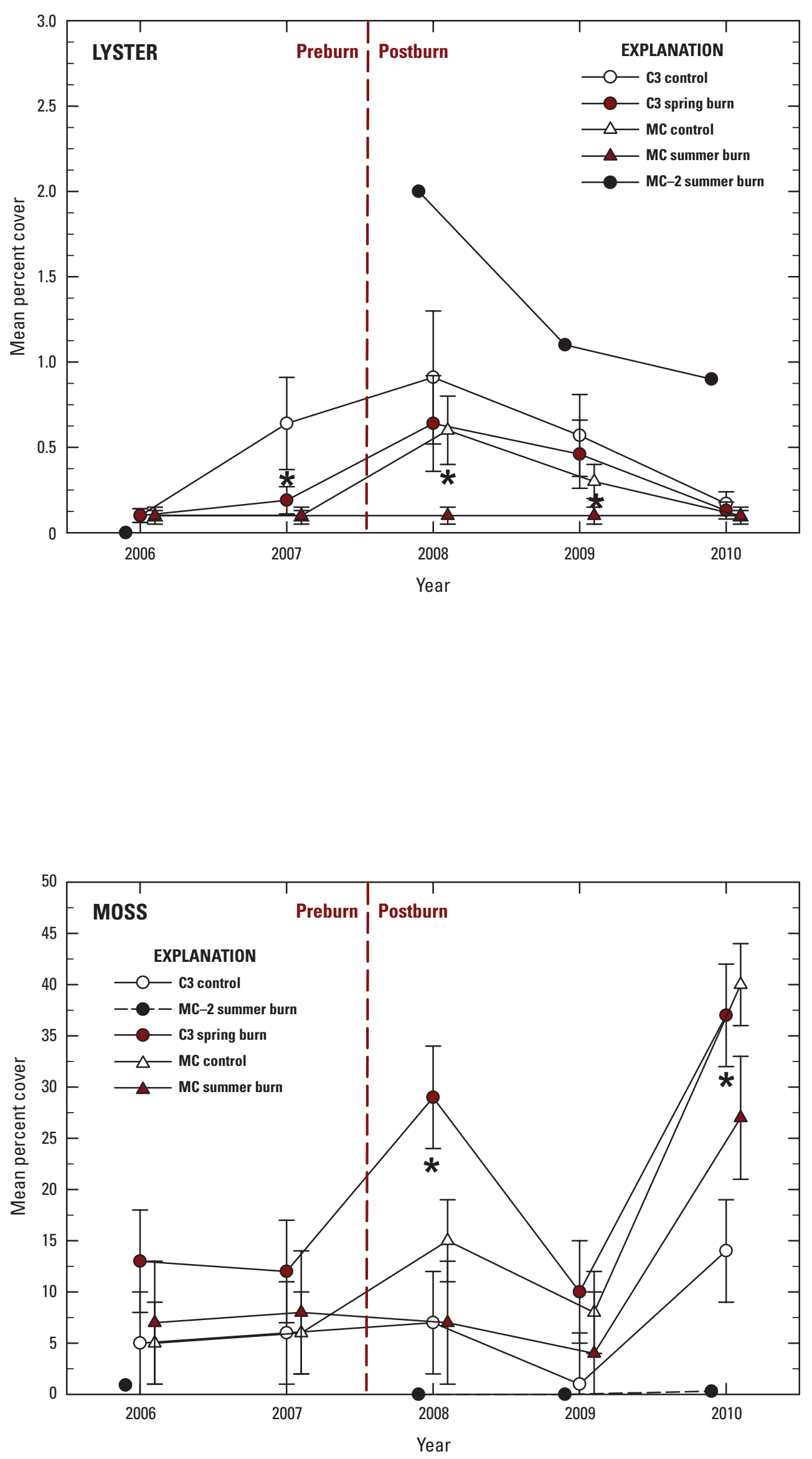

Figure 19. Percent cover of mosses (MOSS) (least-squares means, standard error) affected by separate year and treatment effects in control and burn blocks in C3 and Marsh Creek (MC) blocks, 2006-10, at Seney National Wildlife Refuge, Michigan. Whiskers indicate standard errors. Asterisks indicate significant difference (probability $<0.05$ ) between burn and control blocks within an area and year. 


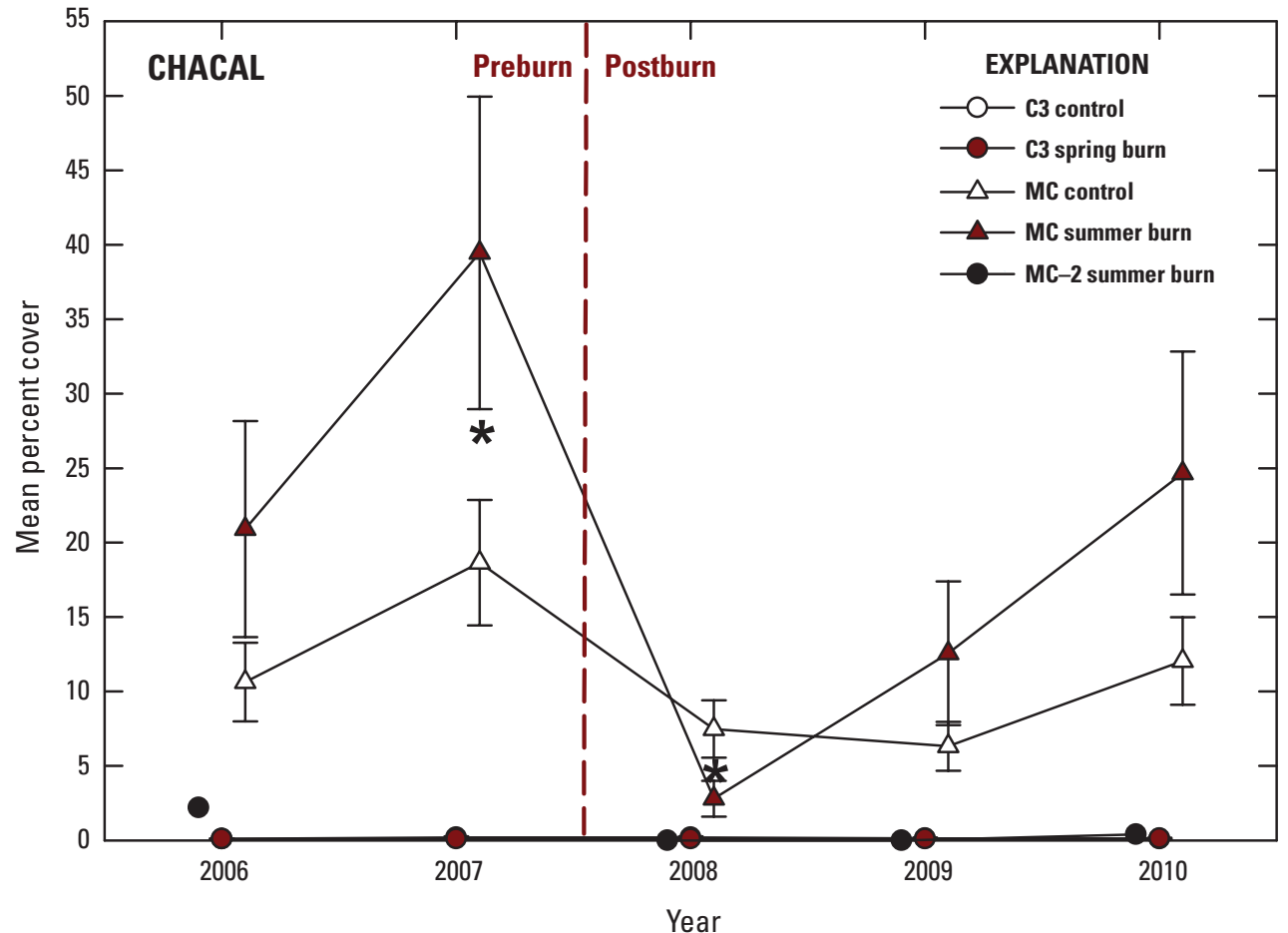

Figure 20. Percent cover of leatherleaf (CHACAL) (least-squares means, standard error) affected by year $\times$ treatment interactions in control and burn blocks in $\mathrm{C} 3$ and Marsh Creek (MC) blocks, 2006-10, at Seney National Wildlife Refuge, Michigan. Whiskers indicate standard errors. Asterisks indicate significant difference (probability $<0.05$ ) between burn and control blocks within an area and year.

\section{Changes in Plant Community Indicated by Ordinations}

The NMS results indicate that two to three axes were adequate for reducing the dimensionality of the plant cover data; axis 1 explained 71 percent, axis 2 explained an additional 12 percent, and axis 3 explained 8 percent. Combined, the three axes explained 91 percent of the plant cover data. NMS scores clearly differentiated C3 and Marsh Creek blocks (fig. 22), with generally more positive scores for $\mathrm{C} 3$ on axes 1 and 2 and positive scores for Marsh Creek on axis 3 in all but 2008. Positive scores on axes 1 and 2 were most highly correlated with elliptic spikerush, spike muhly, and narrowleaved sedges (both axes); white beak-rush (axis 1); and Fraser's marsh St. Johnswort (axis 2). Negative scores were most highly correlated with leatherleaf, creeping sedge, Harlequin blueflag (axis 1), and livid sedge (axis 2; table 5). On axis 3, positive NMS scores were most highly correlated with leatherleaf, bog rosemary, Robbins' spikerush, and livid sedge and negative scores with marsh bellflower, spike muhly, earth loosestrife, and creeping sedge.
ANOVA of NMS scores detected year $\times$ treatment interactions for all three axes (table 4). Statistical comparisons between burn and control blocks within years revealed no differences in NMS scores for C3 in any year. In Marsh Creek, NMS scores were 70 percent lower in summer-burned blocks than control blocks on axis 2 in 2008 and 67 percent lower on axis 1 in 2009; differences between burn and control blocks on axis 3 also were apparent in 2007 and 2008 but were not statistically significant.

Shifts in the plant community across years are apparent by the trajectories of the NMS scores (fig. 22). Comparison of 2007 and 2010 NMS means and confidence intervals indicate NMS axis 1 scores increased 62 percent for C3 control and 87 percent for Marsh Creek burned blocks. For axis 2, scores decreased 58 percent for $\mathrm{C} 3$ burned blocks and (nonsignificantly) 44 percent for Marsh Creek burned blocks. These shifts represent changes after three growing seasons in C3 and two in Marsh Creek. Similar comparisons between 2007 and 2009 NMS scores, representing two and one growing seasons, respectively, also indicated axis 1 scores were 53 percent higher in 2009 for C3 control blocks and axis 2 scores were 114 percent higher in 2009 for Marsh Creek burned blocks. 

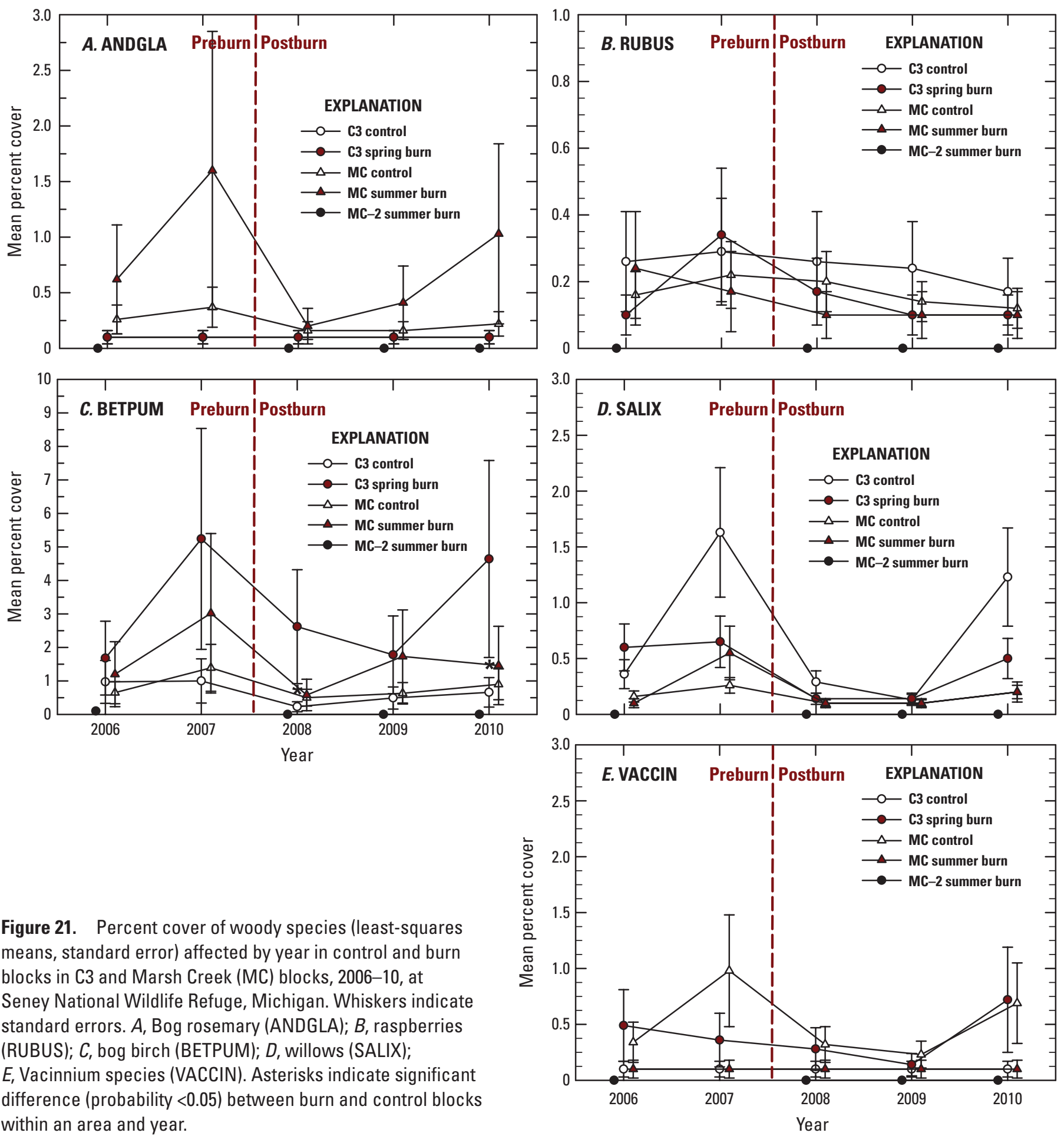

Figure 21. Percent cover of woody species (least-squares means, standard error) affected by year in control and burn blocks in C3 and Marsh Creek (MC) blocks, 2006-10, at Seney National Wildlife Refuge, Michigan. Whiskers indicate standard errors. $A$, Bog rosemary (ANDGLA); $B$, raspberries (RUBUS); $C$, bog birch (BETPUM); $D$, willows (SALIX);

$E$, Vacinnium species (VACCIN). Asterisks indicate significant difference (probability $<0.05$ ) between burn and control blocks within an area and year. 

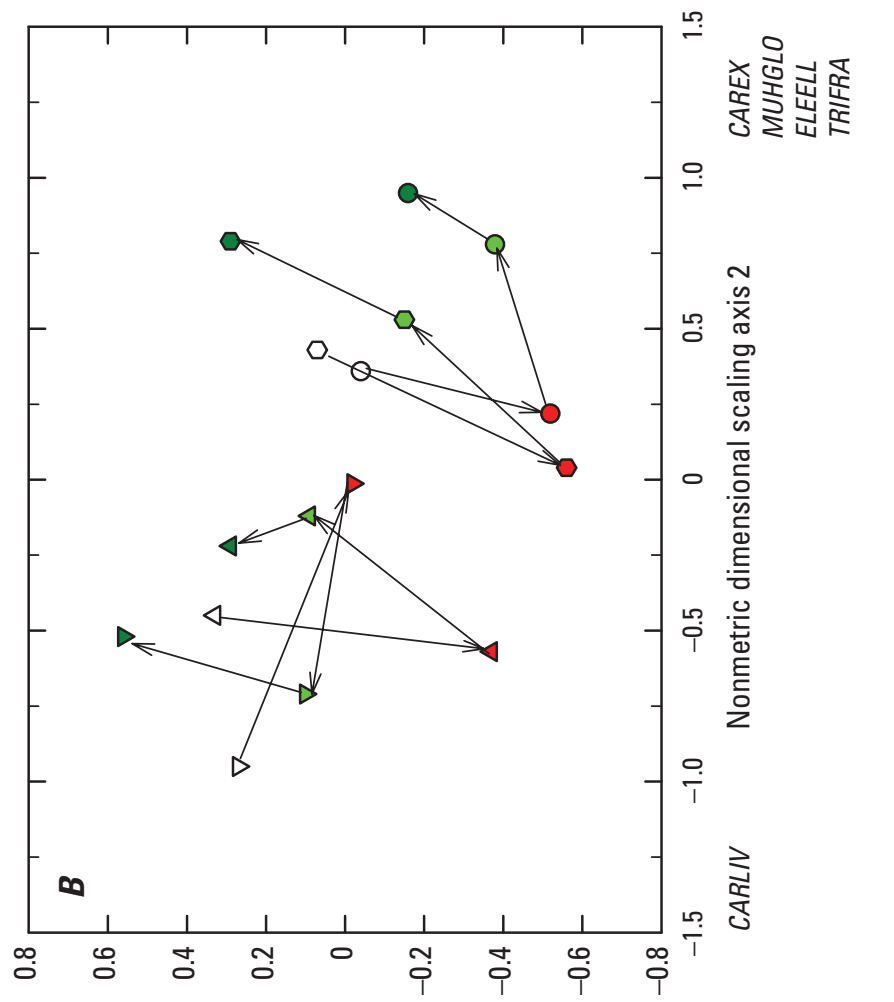

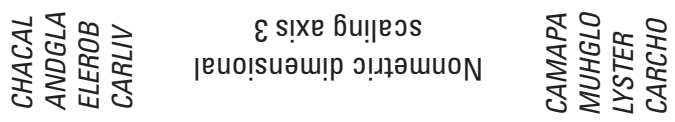

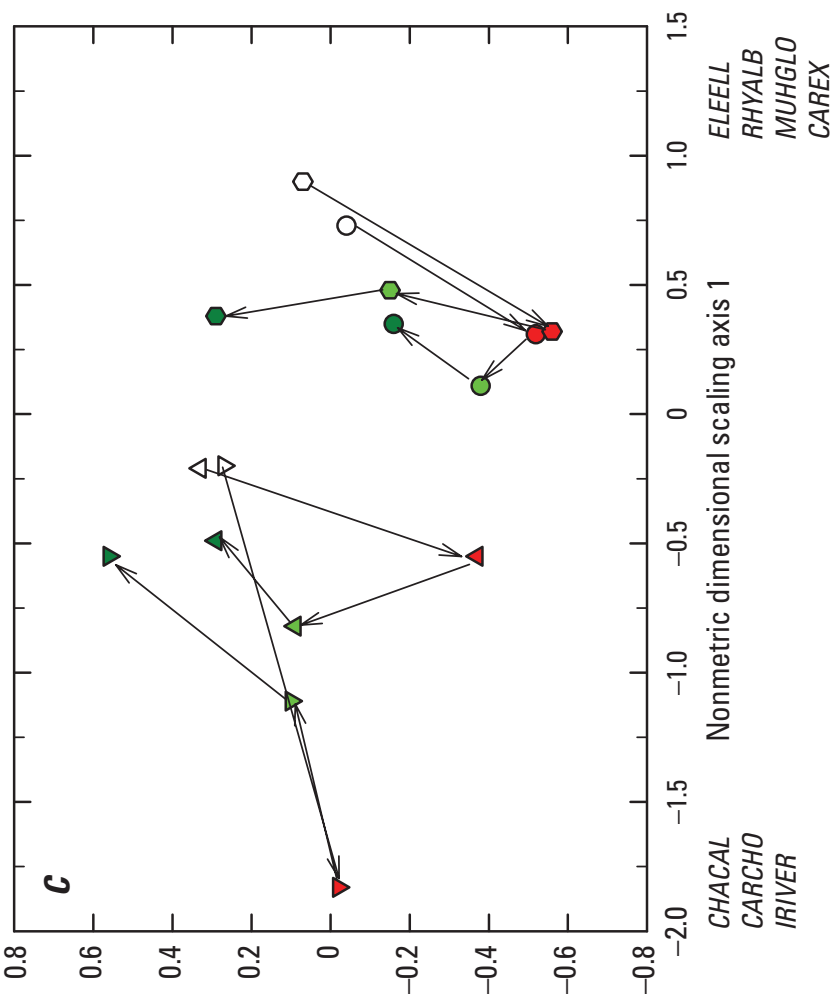

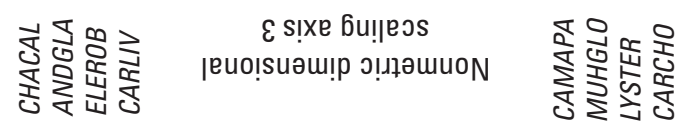
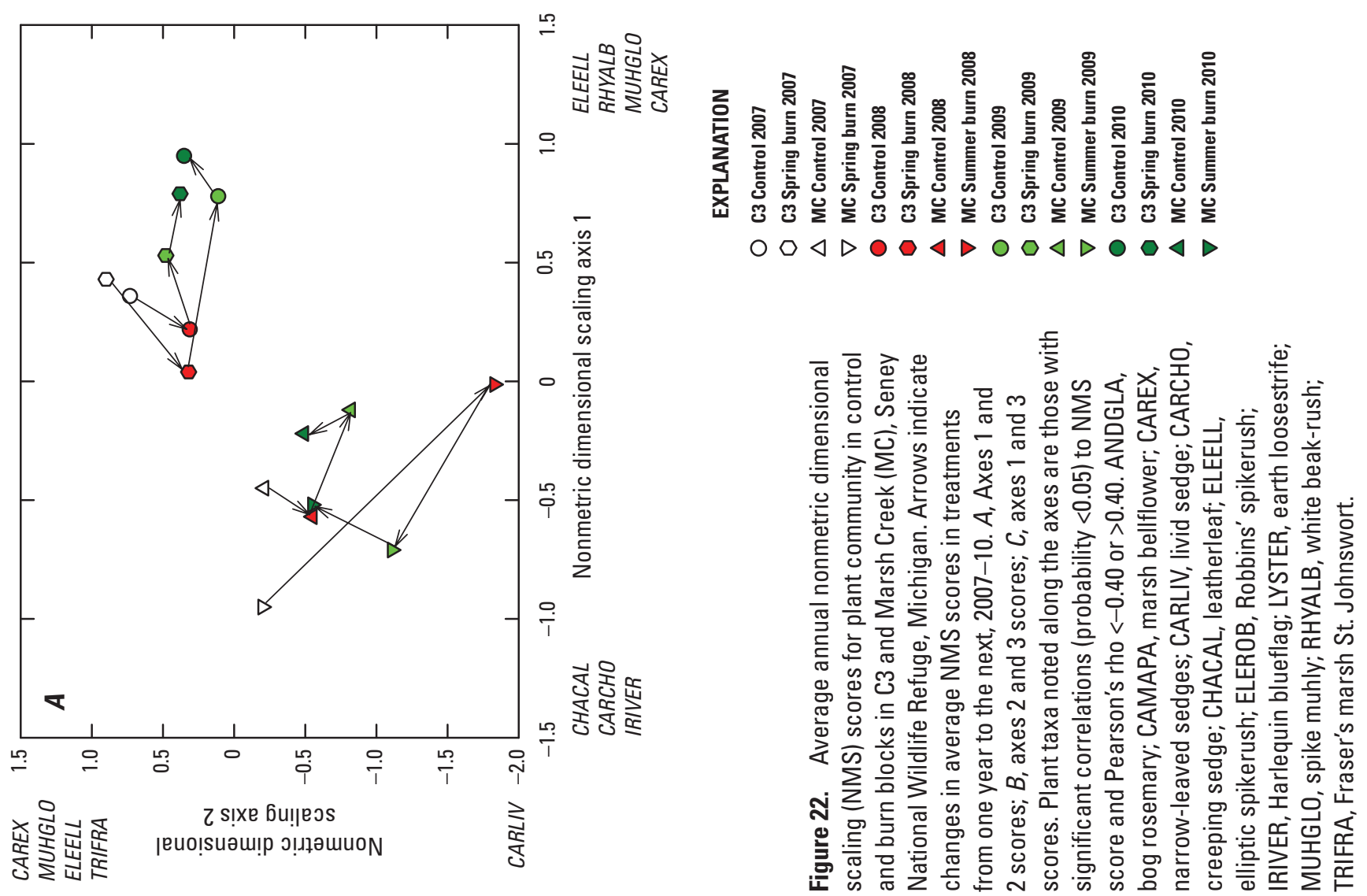
Table 5. Pearson correlation coefficients for 27 most common plant taxa with nonmetric dimensional scaling axes in study blocks in C3 and Marsh Creek study areas, Seney National Wildlife Refuge, Michigan, 2006-10.

[See appendix 1 for taxa codes. $r$, Pearson correlation coefficient; $p$, probability]

\begin{tabular}{|c|c|c|c|c|c|c|}
\hline \multirow{2}{*}{ Plant taxa } & \multicolumn{2}{|c|}{ Axis 1} & \multicolumn{2}{|c|}{ Axis 2} & \multicolumn{2}{|c|}{ Axis 3} \\
\hline & $r$ & $p$-value & $r$ & $p$-value & $r$ & $p$-value \\
\hline ANDGLA & -0.360 & 0.003 & -0.190 & 0.129 & 0.450 & $<0.001$ \\
\hline BETPUM & -0.020 & 0.874 & 0.106 & 0.402 & 0.262 & 0.035 \\
\hline CALCANAG & -0.041 & 0.748 & 0.265 & 0.033 & -0.237 & 0.057 \\
\hline CAMAPA & -0.089 & 0.479 & -0.037 & 0.768 & -0.620 & $<0.001$ \\
\hline CARBUX & -0.136 & 0.279 & -0.189 & 0.132 & 0.257 & 0.038 \\
\hline CARCHO & -0.661 & $<0.001$ & -0.114 & 0.367 & -0.473 & $<0.001$ \\
\hline CAREX & 0.453 & 0.001 & 0.857 & $<0.001$ & -0.297 & 0.016 \\
\hline CARLIV & -0.322 & 0.009 & -0.778 & $<0.001$ & 0.433 & $<0.003$ \\
\hline CHACAL & -0.705 & $<0.001$ & -0.321 & 0.009 & 0.546 & $<0.001$ \\
\hline ELEELL & 0.722 & $<0.001$ & 0.484 & $<0.001$ & -0.235 & 0.060 \\
\hline ELEROB & -0.315 & 0.011 & -0.094 & 0.455 & 0.455 & $<0.001$ \\
\hline ERIOPH & -0.299 & 0.016 & 0.250 & 0.045 & 0.335 & 0.006 \\
\hline GALIUM & -0.375 & 0.002 & -0.104 & 0.409 & 0.276 & 0.026 \\
\hline HYPKAL & -0.331 & 0.007 & -0.106 & 0.400 & 0.290 & 0.019 \\
\hline IRIVER & -0.466 & $<0.001$ & -0.249 & 0.046 & 0.102 & 0.420 \\
\hline LYSTER & 0.145 & 0.249 & 0.050 & 0.694 & -0.490 & $<0.001$ \\
\hline MUHGLO & 0.511 & $<0.001$ & 0.593 & $<0.001$ & -0.496 & $<0.001$ \\
\hline POTFRU & -0.067 & 0.594 & 0.058 & 0.648 & 0.277 & 0.026 \\
\hline RHYALB & 0.615 & $<0.001$ & 0.189 & 0.131 & -0.100 & 0.428 \\
\hline RUBUS & 0.130 & 0.303 & 0.024 & 0.847 & -0.172 & 0.170 \\
\hline SALIX & 0.358 & 0.003 & 0.452 & $<0.001$ & -0.182 & 0.147 \\
\hline SOLULI & -0.309 & 0.012 & -0.030 & 0.813 & 0.359 & 0.003 \\
\hline SYMBOR & -0.282 & 0.023 & 0.310 & 0.012 & 0.280 & 0.024 \\
\hline SYMPUN & -0.154 & 0.221 & -0.282 & 0.023 & -0.095 & 0.452 \\
\hline TRIFRA & 0.040 & 0.752 & 0.432 & $<0.001$ & -0.017 & 0.891 \\
\hline VACCINS & 0.038 & 0.765 & 0.047 & 0.712 & 0.012 & 0.927 \\
\hline VIOLAS & 0.055 & 0.666 & 0.120 & 0.340 & 0.257 & 0.039 \\
\hline
\end{tabular}

\section{Woody Height, Patchiness, and Cover}

Comparisons of woody cover, number of patches, and height were limited to the 2 pretreatment years $(2006,2007)$ and the final posttreatment year (2010). We detected year and treatment effects for mean and standard deviation of height for leatherleaf, bog birch, and tamarack (table 6); however, the only significant difference between burn and control blocks within years was in $\mathrm{C} 3$ (greater leatherleaf height in control blocks in 2006 and 2010) (table 7). We detected no effects of year, treatment, or their interaction for heights of alder, willow, and other woody taxa.

Woody taxa varied in the number of woody patches by year $\times$ treatment interaction (leatherleaf and willow) and year (bog birch, other woody species) (table 8); however, we again detected no significant difference between burn and control blocks within years for either area. The greater prevalence of leatherleaf and other woody taxa in Marsh Creek drove the year $\times$ treatment results, whereas patches of willow were detected mainly in $\mathrm{C} 3$.

Percent cover differed among treatments for leatherleaf and tamarack; by year for bog birch; and by the year $\times$ treatment interaction for willow, other woody taxa, and total woody cover (tables 7 and 8). Once again, however, no withinyear differences between burn and control blocks were significant for either area. Leatherleaf cover tended to be higher in Marsh Creek burn blocks than in control blocks in pre- and posttreatment years. Treatment effect for tamarack was due to its absence in Marsh Creek. Cover of bog birch tended to be higher in 2007 and in C3. Willow and other woody taxa 
Table 6. Results of analysis of variance for woody taxa height and standard deviation of woody height on study blocks in C3 and Marsh Creek study areas, Seney National Wildlife Refuge, Michigan, 2006, 2007, and 2010.

[p, probability; *, significant at $\alpha=0.05]$

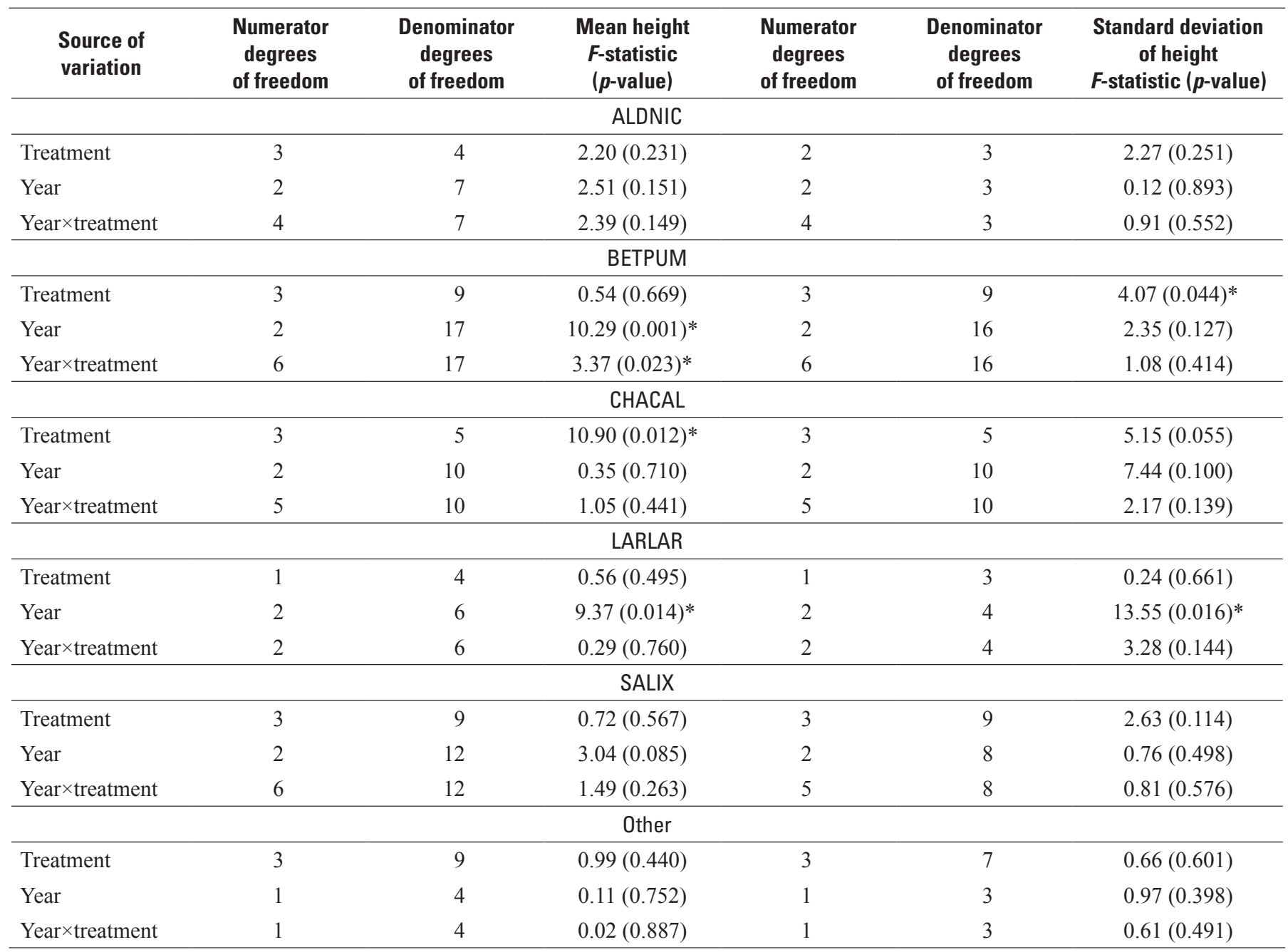

were uncommon, but willow cover tended to be higher in $\mathrm{C} 3$, whereas the other woody taxa were more prevalent in Marsh Creek. Total woody cover was consistently but nonsignificantly higher in Marsh Creek burn blocks than in control blocks and somewhat higher in 2007 and 2010 than in 2006. In $\mathrm{MC}-2$, total shrub cover was initially less than 4 percent and showed little change between 2007 and 2010, although number of patches measured declined from 13 to 7 .

\section{Vertical Cover}

We detected significant interactions of year, treatment, and strata for mean and variability of VORs (table 9). VORs for strata 3-6 $(>66 \mathrm{~cm})$ tended to be higher in C3 than in Marsh Creek, reflecting differences in shrub species and stature (figs. 23-24). No significant differences were detected between control and spring-burned plots in $\mathrm{C} 3$ for any year, but across years, stratum $2(34-66 \mathrm{~cm})$ and 3
(67-99 cm) seemed to be affected by the spring burn and trended downward in 2008 and 2009. In Marsh Creek, after the 2008 summer burn, the VOR of stratum $1(0-33 \mathrm{~cm})$ in burned blocks was 42 percent lower than in control blocks; it then increased 61 percent in 2009 before fully recovering to original levels in 2010. We also detected small but significant differences in mean VORs for stratum $5(134-166 \mathrm{~cm})$ and 6 $(167-200 \mathrm{~cm})$ between control and burn blocks in the 2 years before burning (2006, $0.007 \pm 0.004$ versus $0.001 \pm 0.001$, respectively; 2007, $0.008 \pm 0.004$ versus $0.001 \pm 0.002$ ) (fig. 24). Changes in other strata after burning were nonsignificant. VOR variability differed between Marsh Creek control and burn blocks only in stratum 6, 2 years after burning (2009; control, 0.014 \pm 0.006 ; burn, 0.002 \pm 0.003 ).

In MC-2, mean VORs of strata 1 and 2 declined 50 and 94 percent, respectively, before recovering by 2010 to levels 4 and 41 percent higher than 2006, respectively (fig. 23). VORs for higher strata showed little change over the years (fig. 24). 
Table 7. Mean shrub height (least-squares mean), variation (standard deviation) of height, number of patches, and percent cover for six shrub taxa and total shrub cover at Seney National Wildlife Refuge, Michigan, 2006, 2007, and 2010.

[Means are expressed as least-square means; percent cover is back transformed. C3, C3 study area; *, significant differences within year between control and burn treatments at $\alpha=0.05 ; \mathrm{MC}$, Marsh Creek study area; nd, not detected; nc, not calculated]

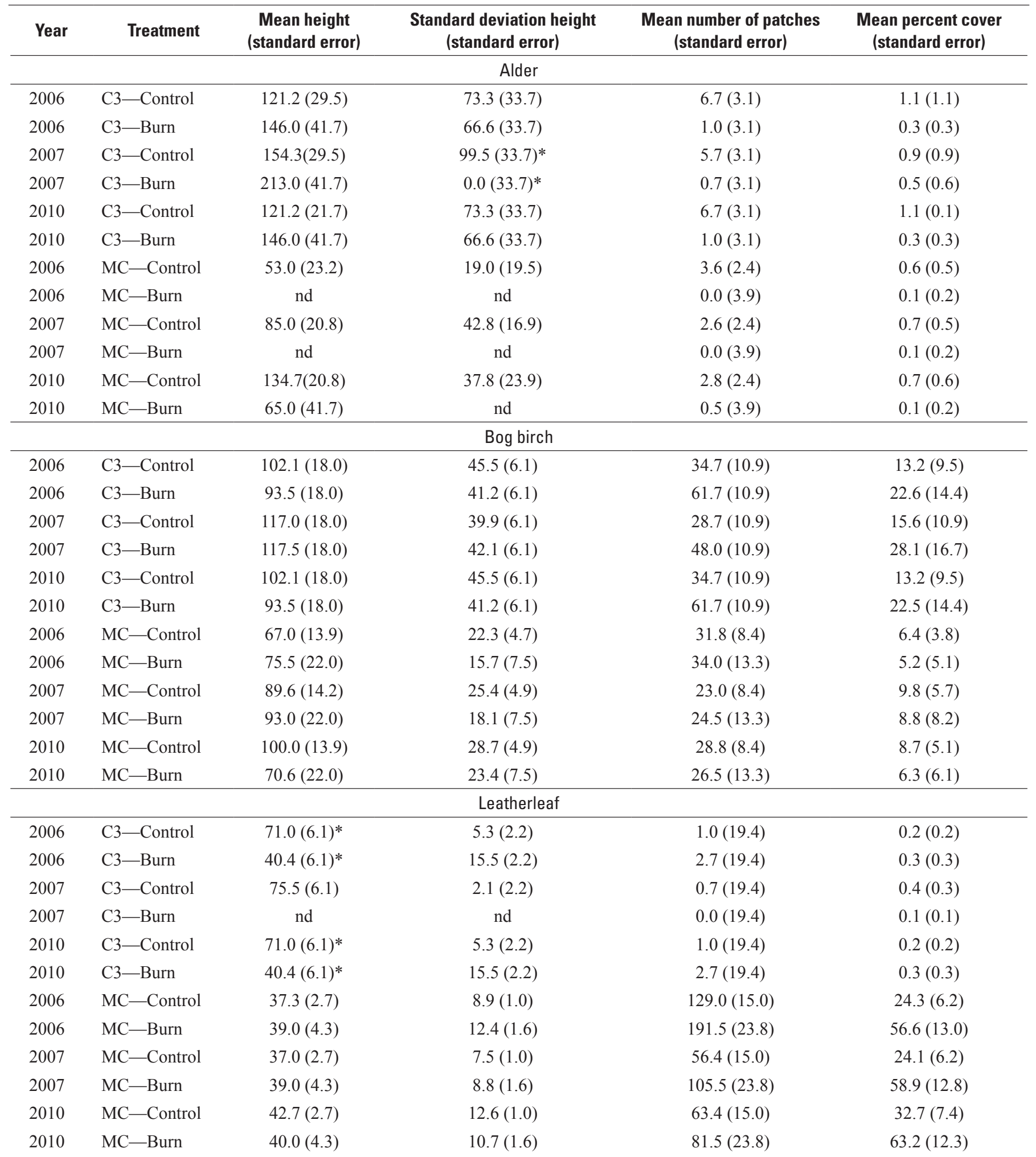


Table 7. Mean shrub height (least-squares mean), variation (standard deviation) of height, number of patches, and percent cover for six shrub taxa and total shrub cover at Seney National Wildlife Refuge, Michigan, 2006, 2007, and 2010.—Continued

[Means are expressed as least-square means; percent cover is back transformed. C3, C3 study area; *, significant differences within year between control and burn treatments at $\alpha=0.05$; MC, Marsh Creek study area; nd, not detected; nc, not calculated]

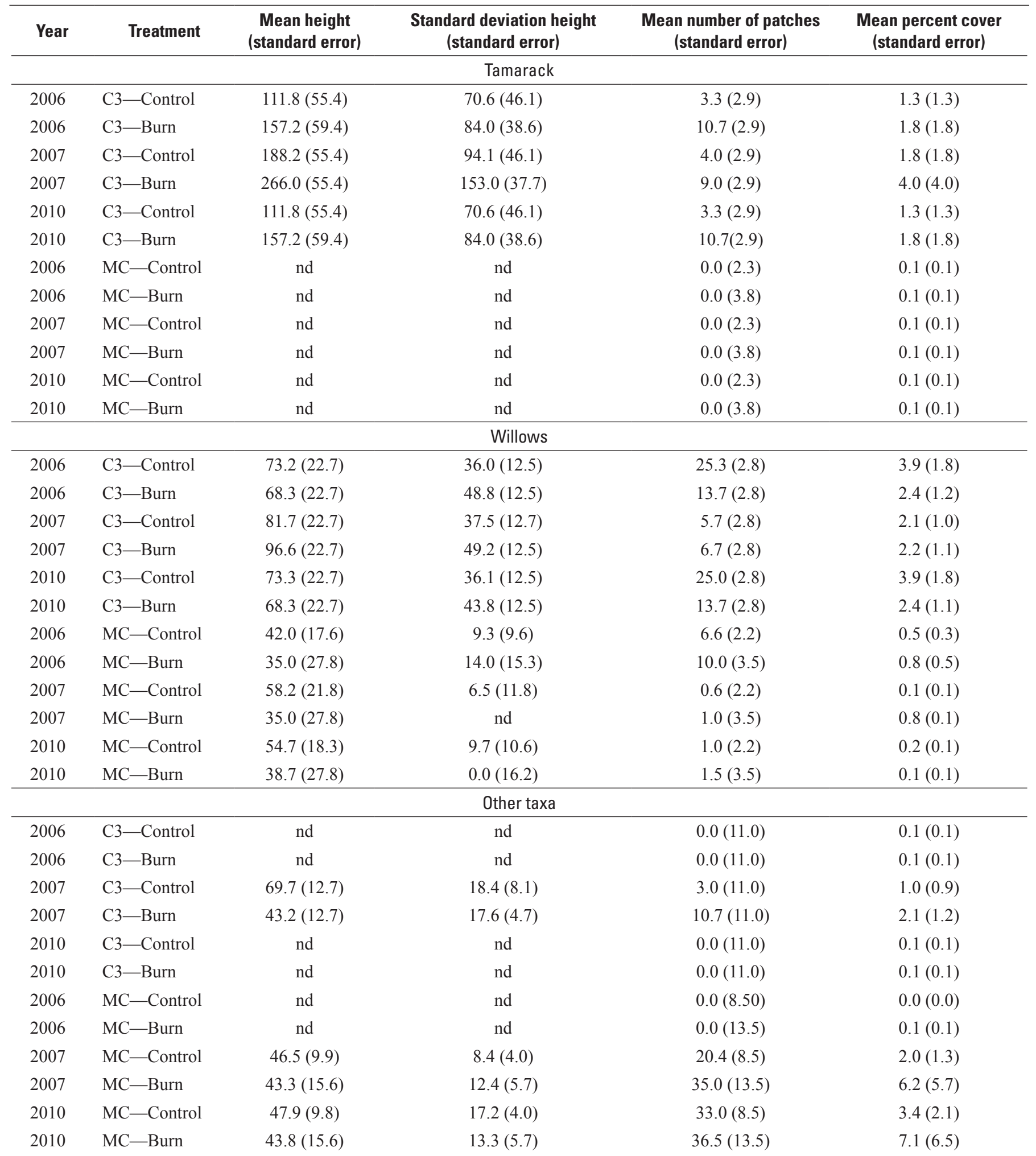


Table 7. Mean shrub height (least-squares mean), variation (standard deviation) of height, number of patches, and percent cover for six shrub taxa and total shrub cover at Seney National Wildlife Refuge, Michigan, 2006, 2007, and 2010.—Continued

[Means are expressed as least-square means; percent cover is back transformed. C3, C3 study area; *, significant differences within year between control and burn treatments at $\alpha=0.05$; MC, Marsh Creek study area; nd, not detected; nc, not calculated]

\begin{tabular}{|c|c|c|c|c|c|}
\hline Year & Treatment & $\begin{array}{c}\text { Mean height } \\
\text { (standard error) }\end{array}$ & $\begin{array}{c}\text { Standard deviation height } \\
\text { (standard error) }\end{array}$ & $\begin{array}{l}\text { Mean number of patches } \\
\text { (standard error) }\end{array}$ & $\begin{array}{c}\text { Mean percent cover } \\
\text { (standard error) }\end{array}$ \\
\hline \multicolumn{6}{|c|}{ Total woody cover } \\
\hline 2006 & $\mathrm{C} 3$ - Burn & $\mathrm{nc}$ & $\mathrm{nc}$ & $\mathrm{nc}$ & $27.1(11.4)$ \\
\hline 2007 & C3-Control & nc & $\mathrm{nc}$ & $\mathrm{nc}$ & $24.1(10.6)$ \\
\hline 2010 & C3-Burn & $\mathrm{nc}$ & $\mathrm{nc}$ & $\mathrm{nc}$ & $27.1(11.4)$ \\
\hline 2006 & $\mathrm{MC}-$ Control & $\mathrm{nc}$ & $\mathrm{nc}$ & $\mathrm{nc}$ & $34.1(10.5)$ \\
\hline 2006 & MC_-Burn & $\mathrm{nc}$ & $\mathrm{nc}$ & $\mathrm{nc}$ & $64.6(16.1)$ \\
\hline 2007 & $\mathrm{MC}-\mathrm{Control}$ & nc & $\mathrm{nc}$ & $\mathrm{nc}$ & $43.3(10.9)$ \\
\hline
\end{tabular}


Table 8. Results of analysis of variance for percent cover and number of patches of woody taxa on study blocks in C3 and Marsh Creek study areas, Seney National Wildlife Refuge, Michigan, 2006, 2007, and 2010.

[ $p$, probability; *, significant at $\alpha=0.05 ;--$, no data; nc, not calculated]

\begin{tabular}{|c|c|c|c|c|c|c|}
\hline $\begin{array}{l}\text { Source of } \\
\text { variation }\end{array}$ & $\begin{array}{c}\text { Numerator } \\
\text { degrees } \\
\text { of freedom }\end{array}$ & $\begin{array}{c}\text { Denominator } \\
\text { degrees } \\
\text { of freedom }\end{array}$ & $\begin{array}{c}\text { Percent cover } \\
\text { F-statistic } \\
\text { (p-value) }\end{array}$ & $\begin{array}{c}\text { Numerator } \\
\text { degrees } \\
\text { of freedom }\end{array}$ & $\begin{array}{c}\text { Denominator } \\
\text { degrees } \\
\text { of freedom }\end{array}$ & $\begin{array}{c}\text { Number of patches } \\
\text { F-statistic } \\
\text { (p-value) }\end{array}$ \\
\hline \multicolumn{7}{|c|}{ ALDNIC } \\
\hline Treatment & 3 & 10.25 & $0.66(0.593)$ & 3 & 9 & $0.77(0.538)$ \\
\hline Year & 2 & 18.63 & $0.04(0.964)$ & 2 & 18 & $0.28(0.761)$ \\
\hline Year $\times$ treatment & 6 & 18.63 & $0.73(0.632)$ & 6 & 18 & $0.08(0.997)$ \\
\hline Treatment & 3 & 8.46 & $0.66(0.600)$ & 3 & 9 & $1.77(0.222)$ \\
\hline Year & 2 & 17.46 & $16.18(<0.001)^{*}$ & 2 & 18 & $13.56(<0.001)^{*}$ \\
\hline Year $\times$ treatment & 6 & 17.46 & $1.26(0.324)$ & 6 & 18 & $1.00(0.456)$ \\
\hline \multicolumn{7}{|c|}{ CHACAL } \\
\hline \multicolumn{7}{|c|}{ LARLAR } \\
\hline Treatment & 3 & 11.71 & $10.08(0.001)^{*}$ & 3 & 9 & $2.95(0.091)$ \\
\hline Year & 2 & 27 & $0.03(0.966)$ & 2 & 18 & $0.12(0.885)$ \\
\hline Year $\times$ treatment & 6 & 20.78 & $1.00(0.449)$ & 6 & 18 & $0.50(0.797)$ \\
\hline \multicolumn{7}{|c|}{ SALIX } \\
\hline Treatment & 3 & 13.31 & $16.76(<0.001)^{*}$ & 3 & 9 & $14.83(0.001)^{*}$ \\
\hline Year & 2 & 27 & $1.70(0.202)$ & 2 & 18 & $18.21(<0.001)^{*}$ \\
\hline Year $\times$ treatment & 6 & 20.6 & $2.78(0.038)^{*}$ & 6 & 18 & $3.95(0.011)^{*}$ \\
\hline \multicolumn{7}{|c|}{ Other } \\
\hline Year $\times$ treatment & 6 & 17.98 & $3.00(0.033)^{*}$ & -- & -- & nc \\
\hline
\end{tabular}


Table 9. Results of analysis of variance for visual obstruction readings for six height strata on study blocks in C3 and Marsh Creek study areas, Seney National Wildlife Refuge, Michigan, 2006-10.

[VOR, visual obstruction reading; $p$, probability; *, significant at $\alpha=0.05$ ]

\begin{tabular}{|c|c|c|c|c|c|c|}
\hline Source of variation & $\begin{array}{c}\text { Numerator degrees } \\
\text { of freedom }\end{array}$ & $\begin{array}{c}\text { Denominator degrees } \\
\text { of freedom }\end{array}$ & \multicolumn{2}{|c|}{ Mean VOR } & \multicolumn{2}{|c|}{ Standard deviation of VOR } \\
\hline Treatment & 3 & 9 & 2.18 & 0.16 & 3.64 & 0.06 \\
\hline Treatment $\times$ strata & 15 & 45 & 2.52 & $0.01^{*}$ & 3.93 & $<0.01^{*}$ \\
\hline Year & 4 & 216 & 51.45 & $<0.01^{*}$ & 27.66 & $<0.01^{*}$ \\
\hline Year $\times$ strata & 20 & 216 & 6.30 & $<0.01^{*}$ & 3.56 & $<0.01 *$ \\
\hline Year $\times$ treatment $\times$ strata & 60 & 216 & 2.80 & $<0.01^{*}$ & 2.18 & $<0.01 *$ \\
\hline
\end{tabular}
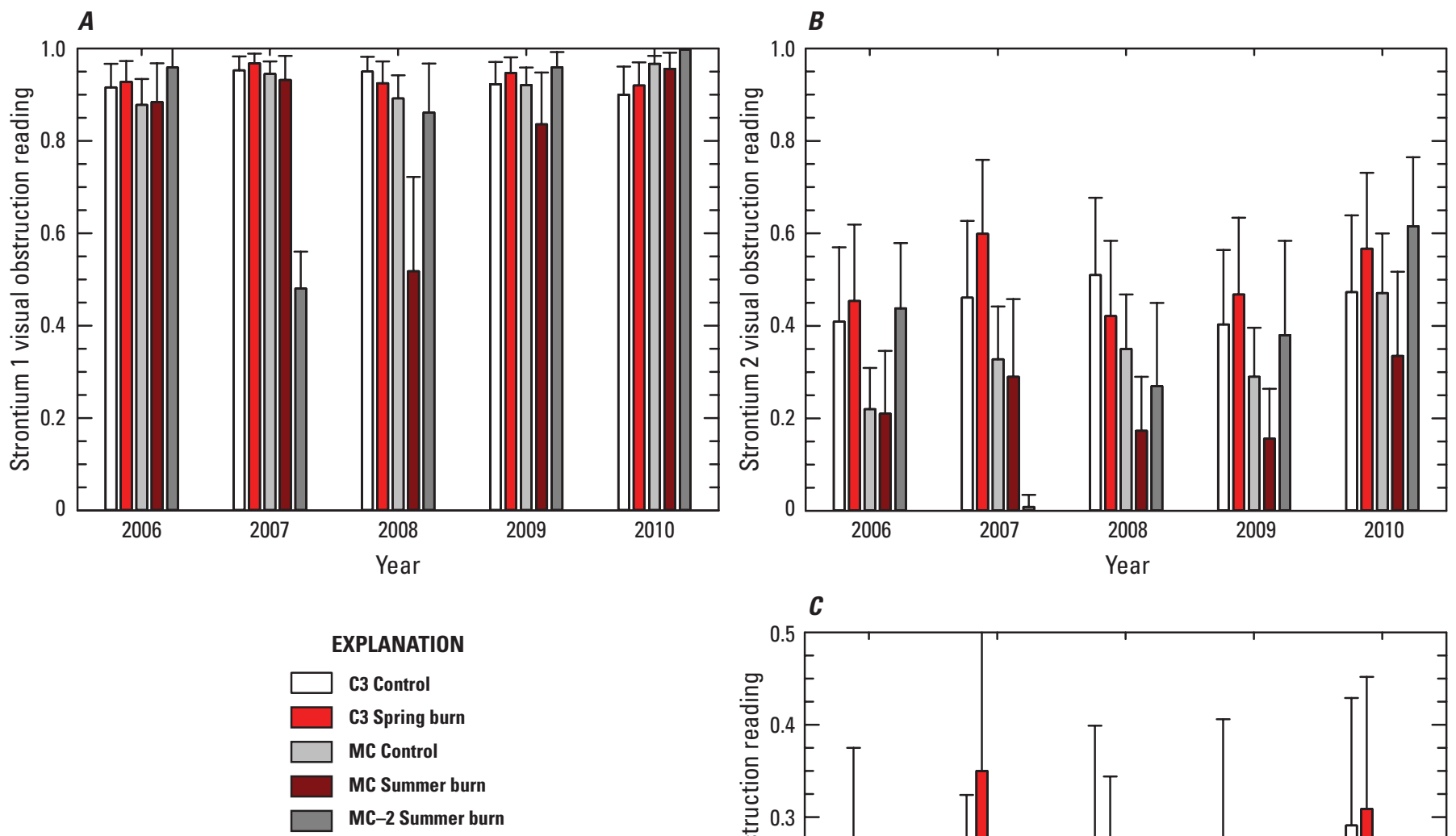

Figure 23. Visual obstruction readings (VORs, least-squares means) in control and burn blocks for 33-centimeter strata in C3, Seney National Wildlife Refuge, Michigan, 2006-10. $A$, Stratum 1; $B$, stratum 2; $C$, stratum 3. C3 was burned in May 2008 and VOR data were collected 2 months later; Marsh Creek was burned in July 2008 and VOR data were collected 3 weeks later. Whiskers indicate standard errors.

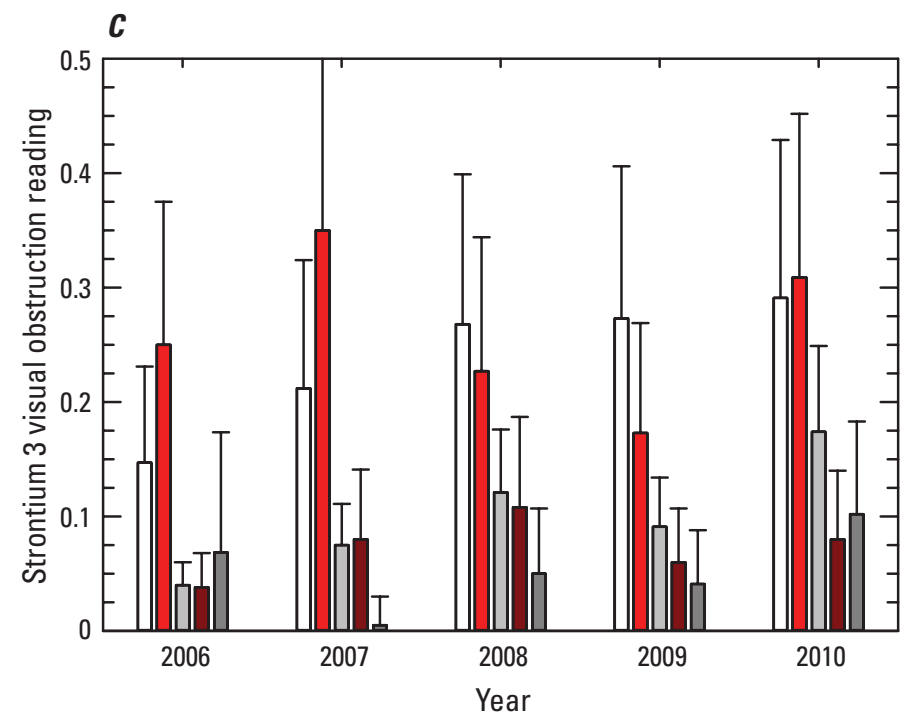



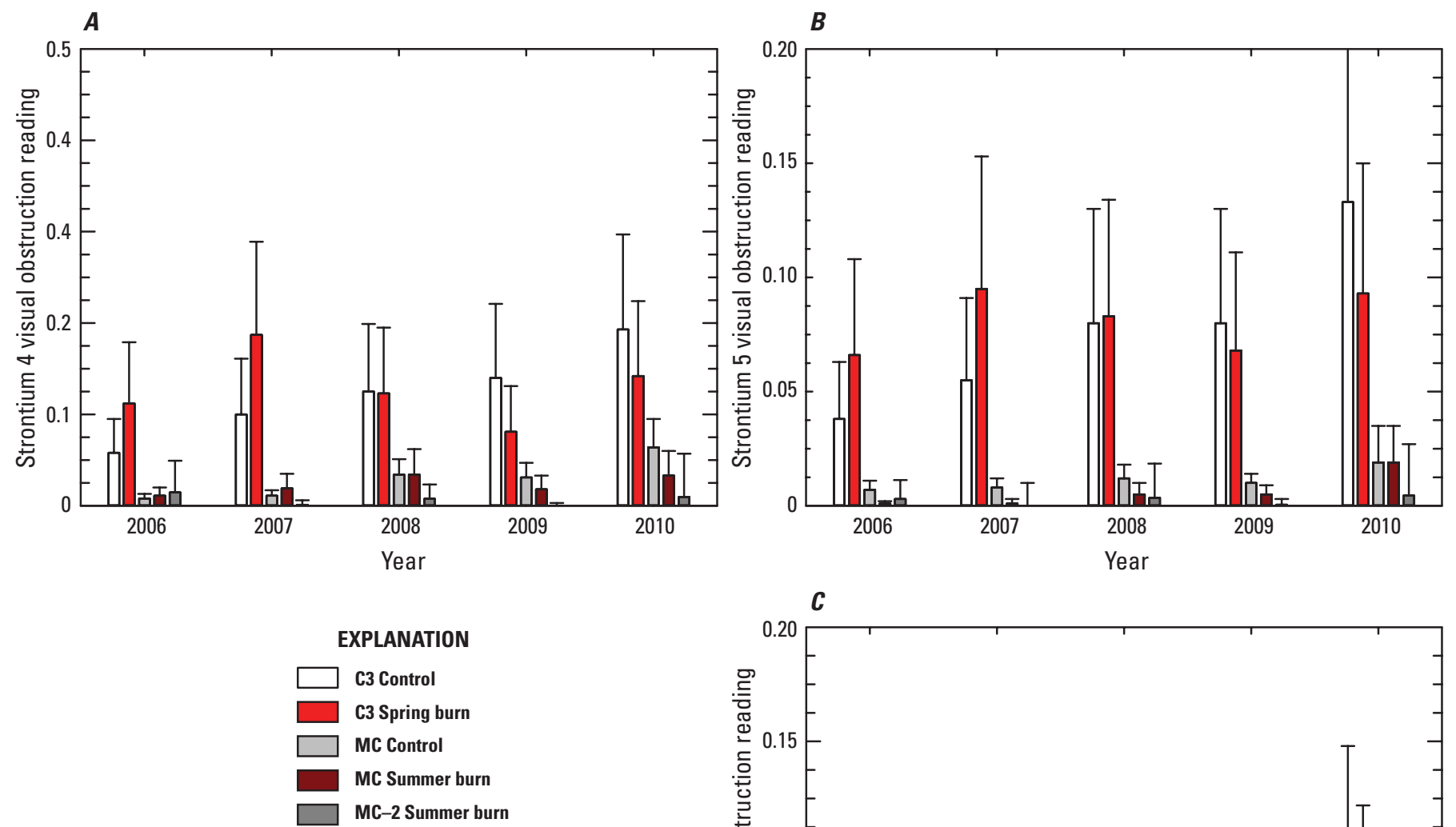

Figure 24. Visual obstruction readings (VORs, least-squares means) in control and burn blocks for 33-centimeter strata in C3, Seney National Wildlife Refuge, Michigan, 2006-10. $A$, Stratum 4; $B$, stratum $5 ; C$, stratum 6 . C3 was burned in May 2008 and VOR data were collected 2 months later; Marsh Creek was burned in July 2008 and VOR data were collected 3 weeks later. Whiskers indicate standard errors.

\section{Discussion}

Burning is considered an important tool in wet grasslands for maintaining biodiversity, but results of our study indicated that summer burns had a greater effect on vegetation than more commonly applied spring burns. We detected few effects of spring burning in $\mathrm{C} 3$, even in the same year of burning. Most vegetation was in early stages of growth at the time of burning and had 11-14 weeks to recover before data collection that year. In Marsh Creek, not surprisingly, most treatment effects were in 2008, when data were collected within 3 weeks of burning and vegetation was just beginning to regrow. Some fire effects there, however, persisted one to two growing seasons $(2009,2010)$. These results concur with other fen studies that reported recovery to preburn conditions within one to two growing seasons after light or moderate fires (Reuter, 1986; Burkman, 1993; Kost and De Steven, 2000; Middleton, 2002). For MC-2, which was burned in summer 2007 under

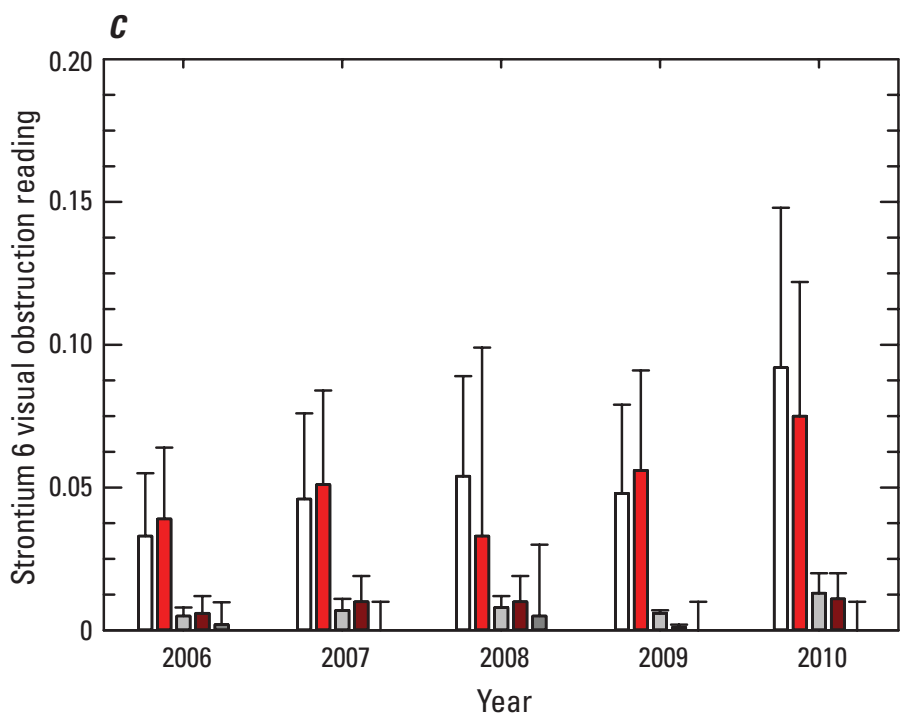

higher fire conditions, some measures did not recover to preburn levels for two to three growing seasons.

The goal of this study was to understand the effects of spring and summer burns on the plant community and structure of fens, and in particular how they change woody structure. Because we wanted treatments to reflect normal prescribed-fire operations, only one burn treatment was applied to an area (that is, Refuge burn unit); hence, differences between spring and summer burns are partially confounded by natural differences in the plant community and hydrology between the two areas, as noted above. Indeed, most of the significant year $\times$ treatment effects were related to differences by area and infrequently by differences between burn and control treatments within an area in the years after burning; moreover, the heterogeneity of these areas is apparent in many variations within and among blocks.

The fire treatments applied in this study in 2008 were under moderate fire conditions for each season and resulted 
in light to moderate burns. Such fire conditions often result in patchy fuel consumption and are not severe enough to burn into the organic substrate to affect the seed bank or root systems. Temperatures of about $60^{\circ} \mathrm{C}$ are considered lethal to most living tissue, but soil temperature is quickly attenuated by moisture, so only the top few centimeters of soil may reach lethal temperatures during light to moderate fires, with minimal effect to species that have deeper root crowns or rhizomes (Flinn and Wein, 1977). The general absence of fire effects in $\mathrm{C} 3$ reflects the cooler and wetter substrate, more moderate spring fire conditions, and low fire severity results; however, this fire was deemed successful in terms of broader fire management goals, which was to open up the brush and promote more sedge to set the stage for a hotter summer burn 14-15 months later (see further discussion of this in the "Fire Management and History in Fens" section). The fire treatments applied in this study differed most markedly between 2007 and 2008. MC-2 was burned in July 2007 under much drier soil conditions and high fire danger rating (table 1), yielding moderate fire severity effect, extensive top kill of shrubs, and longer-lasting effects than in the other Marsh Creek blocks burned 1 year later under more moderate fire conditions, yielding light to variable fire severity effects. The prolonged drought and resulting very high to extreme fire danger conditions in 2007 led to the Sleeper Lake Fen wildfire, $45 \mathrm{~km}$ from the Refuge, just 3 weeks after the MC -2 burn; it burned more than 7,200 ha over 3 months (Bess and others, 2014).

A predominant effect of fire is its consumption of standing vegetation and litter, which exposes the substrate, thereby altering light and temperature conditions, removing a filter for nutrients, and recycling nutrients. The resulting higher albedo and soil temperatures and increased light conditions enhance seed germination and growth and can alter the competitive abilities of species in the seed bank or remaining root systems (Auclair and others, 1973; Smith, 1973; Rooney, 1990; Johnson and Knapp, 1995a, b; Warners, 1997). Change in litter depth was one of the most marked fire effects in this study. Although the 2008 fires did not entirely consume litter, they resulted in reduced and often patchy levels that year, with a lesser decline in C3. Litter depth took two growing seasons to recover after the 2008 summer burn and three growing seasons to recover after the more severe 2007 summer burn. Although litter loss from fire may have played a role in the increasing levels of percent open during the study, the absence of fire effects within year and area, except in the summer-burned blocks in 2008, indicates rapid regeneration of vegetation. Surface water, contributing to litter decomposition, also may have played a role in the trends of percent open. Litter compaction and decomposition were likely less during the dry years of 2005-7 than during the wetter conditions in later years (Neckles and Neill, 1994).

Linked to litter is graminoid height, indicative of aboveground production and future litter deposition. Burning can stimulate aboveground biomass production and reproduction (flowering or seed production) in the first season after burning
(Young, 1987; Bernard and others, 1988; Warners, 1997; Kost and De Steven, 2000; Main and Barry, 2002). However, we detected no evidence of stimulated graminoid growth after spring burning in $\mathrm{C} 3$, and graminoid height took two to three growing seasons to recover after summer burning in Marsh Creek and $\mathrm{MC}-2$. Results instead indicate that other factors such as water conditions and competition from other vegetation contributed to changes in graminoid height. Burkman (1993) also noted annual differences in herbaceous vegetation on both burn and control plots in Marsh Creek related to wetter conditions.

\section{Changes in Plant Community}

Overall, effects of treatment or year $\times$ treatment interactions largely represented spatial differences of species within and among study blocks, and few of the 27 species examined showed clear effects of burning within areas (excluding the expected changes in summer-burned blocks in 2008 because of the timing of sampling). The minimal effect on species richness and diversity in the first growing seasons after burning is not surprising given nearly all taxa characteristic of fens are long-lived perennials such as sedges and leatherleaf that are often clonal and rely on rhizomatous root systems and, therefore, can quickly recover from light to moderate burning. Other studies have similarly reported little change in plant community after burning fens or wet meadows (Cornely and others, 1983; Smith and Kadlec, 1985; Boyd and others, 1993; Austin and others, 2007), but some have reported increased cover of annual forbs in the first year after burning (Kost and De Steven, 2000; Bartels and Wilson, 2001; Middleton, 2002). In the fens examined here, however, all but one forb in the study areas were perennials. Similarly, Kowalski and Wilcox (2003) reported only 1 of 71 plant taxa was an annual in their study of vegetation along the Marsh Creek above and below the $\mathrm{C} 3$ levee and water-control structure. The ordination results also demonstrated that the plant communities tended to return to preburn conditions within two growing seasons of burning.

The fens in this study are composed mostly of obligate or facultative-wet perennial species, which vary in their hydrological niche. Similar trends between control and burn blocks across years for several measures, such as species richness, graminoid height, and NMS scores, indicate seasonal water conditions were an important factor influencing the changes we detected across years and, in some situations, interacted with fire effects. The study began during the second year of a moderate drought and concluded under moderately wet conditions. There was little standing water in the study blocks by July each year except in 2010, when summer rains led to more surface water, particularly on the western end of Marsh Creek (MC-1 and MC-2), which is farther from the levee and other upland areas. Spring flooding conditions were more variable, with greatest depths in 2008 and 2009. 
Sedges comprised more than 40 percent of herbaceous cover, with the narrow-leaved sedges (mainly fewseed and woollyfruit sedge) dominating on most sites. Year $\times$ treatment interactions indicate interactions between local water conditions and fire season - no effects in the first growing season after the spring burn in C3 (2008) but higher cover 1 year later, but sedge cover was lower in both the first and second growing seasons after the Marsh Creek summer burn (2009-10). Some year-to-year differences in narrow-leaved sedge cover and frequency were likely due to different field personnel, but the dry conditions during the pretreatment years resulted in little seed production, which was particularly important for differentiating the narrow-leaved sedges. Flowering and seed production improved in the later, wetter years, but less than 15 percent of stems of woollyfruit and fewseed sedges produced seeds in 2008-10 (J.E. Austin, unpub. data, 2008-10).

Water table and groundwater connectivity are dominant factors driving plant communities of fens and other wetlands (Warners, 1997; Weltzin and others, 2003; Henszey and others, 2004; Little and others, 2010). Seasonal water levels also may contribute to a lag in community responses (Wilcox and Nichols, 2008); for example, bluejoint tends to produce more biomass under drier conditions (Fraser and Karnezis, 2005) and may decline or disappear under persistently flooded conditions (Gates, 1942). For some species, germination, growth, and reproduction after wetter conditions may have contributed to the detection in later years (for example, Buxbaum's sedge in Marsh Creek in 2010). Alternatively, declines in species such as Robbins' spikerush, bedstraws, and northern bog aster may have been related to the shift from drier to wetter conditions during the study.

Some graminoids such as creeping sedge, elliptic spikerush, and spike muhly were common but patchily distributed, which contributed to high variability within treatments and limited our ability to discern any fire effects. Anderson (1982) reported cottongrasses colonized burned fens the spring after the fall 1976 Seney fire, but we detected no difference between burned and control blocks one to two growing season after burning; its earlier abundance in Marsh Creek burn blocks never recovered after 2008. Robbins' spikerush disappeared from Marsh Creek burn blocks after summer burning, but it had been rare in control blocks there. The distinctive white beak-rush was detected only in the westernmost blocks of C3 and was not detected in 2010. Wet conditions may have contributed to the apparent disappearance of this sedge after summer burning.

Fire may stimulate the reappearance of less common species. Marsh bellflower and earth loosestrife had markedly higher abundance one growing season after the summer 2007 fire in MC-2; their abundance in other blocks seemed more driven by annual or site conditions than fire effects. Similarly, Middleton (2002) reported marsh bellflower appearing after a long absence after a winter burn in a Wisconsin sedge meadow. A similar brief stimulus was detected with marked spike in purplestem aster cover in Marsh Creek in 2009, one growing season after the summer burn. In contrast, northern bog aster largely disappeared from MC-2 after 2006 and in all blocks after 2007, indicating water conditions were a key driver. Mosses (predominantly Sphagnum) also seemed to respond to spring burning in the first growing season but likely also were responding to wetter conditions in 2008 and 2010.

Marsh thistle and broadleaf cattail were the only two species of invasive concern detected, but both were detected at low levels and were sparsely distributed. Kowalski and Wilcox (2003) detected marsh thistle along the Marsh Creek drainage above the $\mathrm{C} 3$ pool but not below the pool; we detected it thinly scattered throughout the $\mathrm{C} 3$ study area. Fire may contribute to its occurrence or spread, because it requires open substrate for germination. Although cattail can develop into monotypic stands, in these fens their distribution seems largely adjacent to sources of groundwater seepage (for example, near some areas of greater seepage below the levee along the south side of C3 pool, closer to Sweeney Creek), as noted also by Kowalski and Wilcox (2003); it was not detected in Marsh Creek. The systems' $\mathrm{pH}$ levels likely are an important factor limiting the species' distribution.

Earlier studies at the Refuge reported woollyfruit sedge as the dominant sedge in the Marsh Creek area (Stenzel, 1982; Bart and others, 1984), whereas our study found fewseed sedge to be most common there and woollyfruit sedge to be dominant in C3. Kowalski and Wilcox (2003) also noted woollyfruit sedge as abundant below $\mathrm{C} 3$, in an area west of our study blocks and along the Marsh Creek drainage. We suspect this discrepancy of narrow-leaved taxa occurrence among studies over 28 years relates to spatial and hydrological differences. Stenzel's 1980 study was completed west of the Marsh Creek pool levee (Stenzel, 1982), and therefore, under different hydrological effects, and just 4 years after the 1976 Seney fire (Anderson, 1980). The study area of Bart and others (1984) included western parts of our study area; methods do not indicate how they distinguished Carex species, so they may have assumed the same species as reported in Stenzel's study. Of the six plots in Burkman's (1993) study, four were overlapped with our Marsh Creek area, and two were west of the Marsh Creek pool, similar to that of Stenzel's' (1982) study area. Burkman (1993) reported mean $\mathrm{pH}$ as 6.08 (burned plots) and 6.32 (control plots). Fewseed sedge has a much narrower range of $\mathrm{pH}$ tolerance and is more common in more acidic areas $(\mathrm{pH} \sim 4)$ than woollyfruit and interior sedge ( $\mathrm{pH}>6$; Wheeler and others, 1983; Gignac, 1994; Anderson and others, 1996), which indicates the dominant narrowleaved sedge west of Marsh Creek pool was woollyfruit sedge, as reported by the earlier studies. We did not measure $\mathrm{pH}$ in our study areas, but our results indicate more alkaline conditions immediately below the Marsh Creek pool. Both woollyfruit and fewseed sedges, however, share the narrow-leaved characteristics that provide preferred habitat characteristics of yellow rails. 


\section{Woody Cover and Structure}

We detected no significant effects of either spring or summer burn within years for any of the shrub metrics; rather, treatment effects were largely due to differences between the two areas or among blocks in an area even before burning. Some differences across years may be related to different observers among years (for example, slight shifts in how shrub transects were laid out each year). An earlier fire-effects study in the western part of Marsh Creek in 1991-92 reported total shrub cover was substantially reduced for 2 years after a single dormant-season (spring or fall) burn, primarily because of the reduction of speckled alder (Burkman, 1993). A closer examination of percent cover data (appendices A and B of Burkman, 1993) showed partial recovery of woody cover 2 years after burning in two of the burned plots but no change in woody cover in one of the spring-burned plots. Most shrub taxa in fens have strong resprouting abilities, and fire may only briefly reduce woody dominance (Bowles and others, 1996; Pendergrass and others, 1998; Middleton, 2002; Brisson and others, 2006). Most studies, however, involved surface fires of low intensity and a single fire during the dormant season (often early spring), resulting in high survival of shrubs, resprouting, increased stem densities, and only temporary reduction in cover or height, as observed in this study. Higher fire frequency or more intense fire conditions seem necessary for more lasting control of woody species through increased stress and direct mortality.

Although cover and height metrics showed little fire effects, data for VORs demonstrated some effects of fire and not just at the lowest strata, which was mostly herbaceous vegetation. VORs of intermediate strata (34-99 cm) in Marsh Creek trended downward in 2008 and 2009, indicating less dense growth and likely lower stem densities at these heights one growing season after burning. VORs, however, had recovered to preburn conditions two growing seasons after summer burning. The lower VOR measures indicate shading was temporarily reduced around woody patches, which could alter competition and growth among species. Burkman (1993) reported lower mean vertical cover 1 year after dormantseason burning than in the paired control plots, but she did not differentiate results between the early spring and early fall burns. Keddy (1989) noted that only one-quarter of plant species responded to removal of the shrub sweetgale (Myrica gale); smaller-statured species with high seedbank densities increased after removal, but tall species like bluejoint and common spikerush (Eleocharis palustris), which are more shade tolerant, declined. Overall, Keddy (1989) noted that changes in the plant community took several years to become apparent.

\section{Fire Management and History in Fens}

Most prescribed fires in northern wetlands are implemented under light to moderate conditions, often tied to concerns of safety and controllability; many are therefore done around the dormant season (spring or fall), when temperatures are cooler and fuel moisture is higher. Dormant-season burning also minimizes effects on nesting birds (Beule, 1979; Kantrud, 1986). Such fires are often of low fire severity; leave a mosaic of burned and unburned patches; and have shortterm effects ( $<3$ years), mainly reducing litter and temporarily increasing species diversity with germination of light-sensitive and nonnative invasive species (Thompson and Shay, 1985, 1989; Mallik and Wein, 1986; Shay and others, 1987; Ailstock and others, 2001; Brisson and others, 2006). Single light to moderate burns are ineffective in setting back woody taxa such as alder and willow for more than 1-2 years (Kost and De Steven, 2000; Middleton, 2002; Brisson and others, 2006; this study). Burns at the Refuge were specifically planned and implemented to avoid starting peat fires; thus, killing the below-ground part of vegetation (plant tissue) was never considered achievable. A primary objective of both spring and summer burns on the Refuge was to top-kill the brush in the wetlands. We noted that flame lengths as short as $0.3 \mathrm{~m}$ would top kill the wetland brush; this was observed when the fire was carried under the brush canopy or girdled the brush stem. Experienced fire managers in the region assume that, under a frequent enough fire-return interval, brush density will be reduced because of repeated stress of the fires (G. Lindsay, personal commun., 2018); however, the duration of the project was not long enough to validate this assumption.

Although spring burns on their own may have shortterm effects $(<3$ years), they are valuable for broader fire management goals. Under moderate fire conditions, fire often does not carry into heavy brush because of a lack of fine fuels (primarily grasses and sedges) and moister microclimate. This problem was encountered during a summer burn attempted in C3 in 2004; hence, the goal of the C3 spring fire in 2008 was to top kill the brush and promote more sedge (and therefore, fine fuels) to set the stage for a hot summer burn 14-15 months later, which would be more likely to kill shrubs. The $\mathrm{C} 3$ spring fire achieved those objectives for fire management and set the stage for a followup summer burn. As sometimes happens in fire management, unfortunately, that followup burn was not attempted because of local weather conditions during the summer fire window and national wildfire activity.

Relatively few wetland fire studies have compared results from different burning seasons (Diiro, 1982; Reuter, 1986; Thompson and Shay, 1985, 1989; Shay and others, 1987; Mallik and Wein, 1986; Main and Barry, 2002). Summer burns are more effective than spring or fall burns at reducing biomass and the subsequent year's growth of dominant perennials such as phragmites (Phragmites australis) and broadleaf cattail. With the reduced dominance of such robust perennials, species diversity and richness were higher after 
summer burns (Mallik and Wein, 1986; Thompson and Shay, 1989). Fewer studies have considered the timing of burning relative to target species' growth or flowering phenology (Beule, 1979; van der Toorn and Mook, 1982; Cross, 1983; Krusi and Wein, 1988), despite indications of its importance in early wetland literature (Ward, 1942) and results from upland studies (Knapp and others, 2009). Burning at the end of the growing season after plants have translocated nutrient reserves below ground, during the winter, or in early spring before shoot emergence will have little effect on below-ground reserves and, hence, lessened effect on the subsequent year's growth. Prescribed burns applied in these seasons are largely to remove aboveground biomass to expose more substrate and promote greater germination and growth the following spring. More lasting effects to perennial taxa can be achieved when burns are done when nutrient reserves are aboveground (flowering, active growth) and it is too late in the season for plants to resprout and recoup reserves for the subsequent growing season. As noted in the review by Knapp and others (2009), however, seasonal differences in fuel consumption and fire intensity may be a more important factor in fire effects than plant phenology at the time of the fire. In our study, our goal for summer burns was to top kill shrubs before they began to translocate reserves belowground. However, although some effects of summer burning lasted two growing seasons (three seasons for some measures in $\mathrm{MC}-2$ ), we saw little effect on woody cover or height, and only some reduction in VORs, indicating this strategy is not effective or requires greater fire intensity to set back woody cover than we were able to achieve.

Most wildfires in temperate wetland systems occur during drier conditions of summer and early fall and can be most intense during drought - conditions that are avoided by fire managers but are more likely to set back woody encroachment. The prolonged drought in 2007 prevented the Refuge fire staff from fully implementing the Refuge burn plan and our BACI design as planned; however, results for the area we did burn that summer (MC-2) indicated longer-lasting effects than the areas burned under the more moderate fire conditions and wetter landscape the following year. In the areas of the Refuge burned more intensely during the summer and fall of 1976, bog birch and willow did not recolonize the area until nearly 3 years after the fire (Anderson, 1982). Photographs of the Marsh Creek study area taken in June 1982, 6 years after the fire, show a low density of low-stature shrubs (Stenzel, 1982). More recently, the land cover type derived from 2004 aerial imagery delineated this study area as lowland shrub, 25-60 percent cover, similar to the types encompassed in most of our study areas.

Before European settlement, fire was probably an important natural disturbance factor in the fens of Wisconsin (Curtis, 1959) and elsewhere in the north-central region (Prince,

1997). Droughts and logging during the late 1800 s to the early 1900s contributed to the severe wildfires that burned both uplands and wetlands. Before settlement (1840-56), General Land Office surveys indicated 23 percent of the U.S. Forest
Service's Seney Subdistrict of Michigan's upper Peninsula was large patches of wetlands, including emergent and shrubdominated wetlands (Comer and others, 1995). By the 1950s, fire suppression on uplands, combined with wetland drainage efforts, led to reduced wetland size and woody encroachment into wetlands (Curtis, 1959; Jahn and Hunt, 1964). Jahn and Hunt (1964:54) reported that "[u]nder present-day, strict fire protection, new depressions are rarely burned in meadows, and sedges and grasses give way to shrubs and trees." By 1990, wetlands and water bodies in the Seney Subdistrict had declined to 10 percent (Zhang and others, 2000).

Prescribed fire programs on public lands in this region began in the 1990s, primarily to restore fire to the region's fire-dependent forest ecosystems; the fire program began at the Refuge in 2000. Prescribed burning is recognized as an important management tool used to restore and manage fens in this Refuge for yellow rails, sedge wrens, Le Conte's sparrows, and other birds (U.S. Fish and Wildlife Service, 2009), as well as restoring fens on other conservation lands (Middleton and others, 2006). Given the short-term effects of light to moderate spring or summer burns, such fires will have little effect on breeding birds other than temporary loss of ground-nesting conditions within the first growing season after burning. Fire can, however, be useful for creating more diverse habitat conditions spatially and temporally (Anderson, 1982).

\section{Rethinking Fire Management for Controlling Woody Encroachment in Fens}

The open and partially wooded fens at Seney National Wildlife Refuge are dominated by perennial wetland plants that are largely resistant to surface fires. Light to moderate spring burns had minor effects on plant community, vegetative cover, and woody vegetation in even the first growing season after burning, whereas summer burns had somewhat longerlasting effects, mainly reducing fine fuels (litter, lower VORs). The summer 2007 burn completed under drought conditions was closer to achieving habitat objectives, but all measures recovered within two to three growing seasons. Some changes in plant cover indicate seasonal water conditions were important and interacted with burning. Our results demonstrated the heterogeneity of plant community and environmental conditions within and among areas. Differences that were detected largely represented spatial differences in the plant community within and among the two study areas.

Maintaining or restoring more open conditions in fens may require different approaches to water management, more aggressive fire management (for example, shorter fire-return interval, more intense fires, or burning during drier conditions), or the combination of fire with other tools such as cutting. Although of little apparent effect on their own, spring burns can be useful where woody cover limits the effective 
use of summer burns by setting up conditions for later summer burns that can be more effective in setting back woody cover. Important to understanding fire effects is the documentation of preburn environmental conditions, such as water, substrate, and fuel conditions, and phenology of primary taxa of interest; weather and fuel conditions during the fire; and fire severity immediately after the burn. Few fire studies report these measures, which limits ability to compare or interpret effects among fires or studies. Longer-term ( $>3$ years) or more substantial changes to the plant community, particularly reducing the dominance of woody plants, will likely require targeting the timing and intensity of fires to reduce the vigor or kill perennial plants. Longer-term studies or monitoring are needed to detect interactions between fire disturbances and water or other environmental conditions and to detect longterm shifts in the plant community and structure.

\section{References Cited}

Ailstock, M.S., Norman, C.M., and Bushmann, P.J., 2001, Common reed Phragmites australis - Control and effects upon biodiversity in freshwater nontidal wetlands: Restoration Ecology, v. 9, no. 1, p. 49-59. [Also available at https://doi.org/10.1046/j.1526-100x.2001.009001049.x.]

Anderson, S.H., comp., 1982, Effects of the 1976 Seney National Wildlife Refuge wildfire on wildlife and wildlife habitat: Washington, D.C., U.S. Fish and Wildlife Service Resource Publication 146, 28 p.

Anderson, D.S., Davis, R.B., Rooney, S.C., and Campbell, C.S., 1996, The ecology of sedges (Cyperaceae) in Maine peatlands: Bulletin of the Torrey Botanical Club, v. 123, no. 2, p. 100-110. [Also available at https://doi.org/10.2307/2996067.]

Auclair, A.N., Bouchard, A., and Pajaczkowski, J., 1973, Plant composition and species relations on the Huntingdon Marsh, Quebec: Canadian Journal of Botany, v. 51, p. 12311247. [Also available at https://doi.org/10.1139/b73-154.]

Austin, J.E., 2018, Effects of fire on vegetation in fens at Seney National Wildlife Refuge: U.S. Geological Survey data release, https://doi.org/10.5066/P90P8VWJ.

Austin, J.E., and Buhl, D.A., 2013, Relating yellow rail (Coturnicops noveboracensis) occupancy to habitat and landscape features in the context of fire: Waterbirds, v. 36, no. 2, p. 199-213. [Also available at https://doi.org/10.1675/063.036.0209.]

Austin, J.E., Keough, J.R., and Pyle, W.H., 2007, Effects of habitat management treatments on plant community composition and biomass in a montane wetland: Wetlands, v. 27, no. 3 , p. $570-587$.
Bart, J., Stehn, R.A., Herrick, J.A., Heaslip, N.A., Bookhout, T.A., and Stenzel, J.R., 1984, Survey methods for breeding yellow rails: Journal of Wildlife Management, v. 48, no. 4, p. 1382-1386. [Also available at https://doi.org/10.2307/3801802.]

Bartels, M.R., and Wilson, M.V., 2001, Fire and mowing as management tools for conserving a threatened perennial and its habitat in the Willamette Valley, Oregon in Proceedings of the 17th North American Prairie Conference: Corvallis, Oreg., Oregon State University, Department of Botany and Plant Pathology, p. 59-65.

Bernard, J.M., Solander, D., and Květ, J., 1988, Production and nutrient dynamics in Carex wetlands: Aquatic Botany, v. 30, no. 1-2, p. 125-147. [Also available at https://doi.org/10.1016/0304-3770(88)90011-3.]

Bess, J., Chimner, R., and Kangas, L., 2014, Ditch restoration in a large northern Michigan fen-Vegetation response and basic porewater chemistry: Ecological Restoration, v. 32, no. 3, p. 260-274. [Also available at https://doi.org/10.3368/ er.32.3.260.]

Beule, J.D., 1979, Control of cattails and management of cattails in southeastern Wisconsin wetlands: Madison, Wisc., Wisconsin Department of Natural Resources Technical Bulletin 12, p. 13-25.

Boelter, D.H., and Verry, E.S., 1977, Peatland and water in the northern lake states: St. Paul, Minn., North Central Forest Experimental Station, U.S. Department of Agriculture, Forest Service, General Technical Report NC-31, 26 p.

Bookhout, T.A., and Stenzel, J.R., 1987, Habitat and movements of breeding yellow rails: Wilson Bulletin, v. 99, no. 3, p. $441-447$.

Bork, S.P., Pypker, T.G., Corace, R.G., III, Chimner, R.A., MacLean, A.L., and Hribljan, J.A., 2013, A case study in large-scale wetland restoration at Seney National Wildlife Refuge, Upper Michigan, USA: American Midland Naturalist, v. 169, no. 2, p. 286-302. [Also available at https://doi.org/10.1674/0003-0031-169.2.286.]

Bowles, M., McBride, J., Stoynoff, N., and Johnson, K., 1996, Temporal changes in vegetation composition and structure in a fire-managed prairie fen: Natural Areas Journal, v. 16, no. 4, p. 275-288.

Boyd, R.S., Woodward, R.A., and Walter, G., 1993, Fire effects on a montane Sierra Nevada meadow: California Fish and Game, v. 79, no. 3, p. 115-125.

Brisson, J., Cogliastro, A., and Robert, M., 2006, Controlling speckled alder (Alnus incana ssp. rugosa) invasion in a wetland reserve of southern Quebec: Natural Areas Journal, v. 26, p. 78-83. [Also available at https://doi.org/10.3375/0885-8608(2006)26[78:CSAAIS]2. 0.CO;2.] 
Burkman, M.A., 1993, The use of fire to manage breeding habitat for yellow rails: Marquette, Mich., Northern Michigan University, M.S. thesis, 67 p.

Chadde, S.W., 2002, A Great Lakes wetland flora (2d ed.): Laurium, Mich., PocketFlora Press, 648 p.

Comer, P., Albert, D., Wells, H., Hart, B., Raab, J., Price, D., Kashian, D., Corner, R., and Schuen, D., 1995, Michigan's native landscape-As interpreted from the General Land Office Surveys 1816-1856: Lansing, Mich., Michigan Natural Features Inventory, $76 \mathrm{p}$.

Committee on the Status of Endangered Wildlife in Canada, 2009, COSEWIC assessment and status report on the yellow rail Coturnicops noveboracensis in Canada: Ottawa, Ontario, Committee on the Status of Endangered Wildlife in Canada, accessed August 7, 2017, at https://registrelep.gc.ca/virtual_sara/files/cosewic/sr_ Yellow\%20Rail_0810_e.pdf.

Cornely, J.E., Britton, C.M., and Sneva, F.A., 1983, Manipulation of flood meadow vegetation and observations on small mammal populations: Prairie Naturalist, v. 15, no. 1, p. 16-22.

Cross, D.H., 1983, Wildlife habitat improvement by control of Phragmites communis with fire and herbicide: Fort Collins, Colo., Colorado State University, M.S. thesis, 81 p.

Crow, G.E., and Hellquist, C.B., 2000a, Aquatic and wetland plants of northeastern North America, v. I: Madison, Wisc., University of Wisconsin Press, 480 p.

Crow, G.E., and Hellquist, C.B., 2000b, Aquatic and wetland plants of northeastern North America, v. II: Madison, Wisc., University of Wisconsin Press, 400 p.

Curtis, J.T., 1959, The vegetation of Wisconsin: Madison, Wisc., University of Wisconsin Press, 704 p.

Dechant, J.A., Sondreal, M.L., Johnson, D.H., Igl, L.D., Goldade, C.M., Zimmerman, A.L., and Euliss, B.R., 2002a, Effects of management practices on grassland birdsLe Conte's sparrow: Jamestown, N. Dak., Northern Prairie Wildlife Research Center, $144 \mathrm{p}$.

Dechant, J.A., Sondreal, M.L., Johnson, D.H., Igl, L.D., Goldade, C.M., Parkin, B.D., and Euliss, B.R., 2002b, Effects of management practices on grassland birds - Sedge wren: Jamestown, N. Dak., Northern Prairie Wildlife Research Center, $137 \mathrm{p}$.

Diiro, B.W., 1982, Effects of burning and mowing on seasonal whitetop ponds in southern Manitoba: Ames, Iowa, Iowa State University, M.S. thesis, 48 p.
Elzinga, C.L., Salzer, D.W., and Willoughby, J.W., 1998, Measuring and monitoring plant populations: Denver, Colo., Bureau of Land Management Technical Reference 1730-1, $474 \mathrm{p}$.

Flinn, M.A., and Wein, R.W., 1977, Depth of underground plant organs and theoretical survival during fire: Canadian Journal of Botany, v. 55, p. 2550-2554. [Also available at https://doi.org/10.1139/b77-291.]

Flora of North America Editorial Committee, eds., 2003, Flora of North America North of Mexico, v. 4: New York, Oxford University Press, $512 \mathrm{p}$.

Fraser, L.H., and Karnezis, J.P., 2005, A comparative assessment of seedling survival and biomass accumulation for fourteen wetland plant species grown under minor water-depth differences: Wetlands, v. 25 , no. 3 , p. 520-530. [Also available at https://doi.org/10.1672/02775212(2005)025[0520:ACAOSS]2.0.CO;2.]

Gates, F.C., 1942, The bogs of northern lower Michigan: Ecological Monographs, v. 12, no. 3, p. 213-254. [Also available at https://doi.org/10.2307/1943542.]

Gbur, E.E., Stroup, W.W., McCarter, K.S., Durham, S., Young, L.J., Christman, M., West, M., and Kramer, M., 2012, Analysis of generalized mixed models in the agricultural and natural resources sciences: Madison, Wisc., American Society of Agronomy, Soil Science Society of America, and Crop Science Society of America, 276 p., accessed November 20, 2017, at https://doi.org/10.2134/2012.generalizedlinear-mixed-models.

Gignac, L.D., 1994, Peatland species preferences-An overview of our current knowledge base: Wetlands, v. 14, no. 3, p. 216-222. [Also available at https://doi.org/10.1007/ BF03160658.]

Goldade, C.M., Dechant, J.A., Johnson, D.H., Zimmerman, A.L., Jamison, B.E., Church, J.O., and Euliss, B.R., 2002, Effects of management practices on wetland birds-Yellow rail: Jamestown, N. Dak., Northern Prairie Wildlife Research Center, 21 p., accessed May 1, 2012, at https://www.npwrc.usgs.gov/resource/literatr/wetbird/yera/ yera.htm.

Hanowski, J.M., Christian, D.P., and Nelson, M.C., 1999, Response of breeding birds to shearing and burning in wetland brush ecosystems: Wetlands, v. 19, no. 3, p. 584-593. [Also available at https://doi.org/10.1007/BF03161696.]

Harrell, W.C., and Fuhlendorf, S.D., 2002, Evaluation of habitat measures in a shrubland community: Journal of Range Management, v. 55, no. 5, p. 488-493. [Also available at https://doi.org/10.2307/4003227.] 
Henszey, R.J., Pfeiffer, K., and Keough, J.R., 2004, Linking surface- and ground-water levels to riparian grassland species along the Platte River in central Nebraska, USA: Wetlands, v. 24, no. 3, p. 665-687. [Also available at https://doi.org/10.1672/0277-5212(2004)024[0665:LSAGL $\mathrm{T}] 2.0 . \mathrm{CO} ; 2$.

Jahn, L.R., and Hunt, R.A., 1964, Duck and coot ecology and management in Wisconsin: Madison, Wisc., Wisconsin Conservation Department Technical Bulletin 33, 212 p.

Johnson, S.R., and Knapp, A.K., 1995a, The influence of fire on Spartina pectinata wetland communities in a northeastern Kansas tallgrass prairie: Canadian Journal of Botany, v. 73, no. 1, p. 84-90. [Also available at https://doi.org/10.1139/b95-011.]

Johnson, S.R., and Knapp, A.K., 1995b, The role of fire in Spartina pectinata-dominated tallgrass prairie wetlandsFire in wetlands-A management perspective: Proceedings of the Tall Timbers Fire Ecology Conference, v. 19, p. $92-101$.

Kantrud, H.A., 1986, Effects of vegetation manipulation on breeding waterfowl in prairie wetlands-A literature review: Washington, D.C., U.S. Fish and Wildlife Service Wildlife Technical Report 3, 15 p.

Keddy, P.A., 1989, Effects of competition from shrubs on herbaceous wetland plants-A 4-year field experiment: Canadian Journal of Botany, v. 67, no. 3, p.708-716. [Also available at https://doi.org/10.1139/b89-094.]

Knapp, E.E., Estes, B.L., and Skinner, C.N., 2009, Ecological effects of prescribed fire season-A literature review and synthesis for managers: Albany, Calif., U.S. Forest Service, Pacific Southwest Research Station, General Technical Report PSW-GTR-224. 86 p.

Kost, M.A., and De Steven, D., 2000, Plant community responses to prescribed burning in Wisconsin sedge meadows: Natural Areas Journal, v. 20, no. 1, p. 36-45.

Kowalski, K.P., and Wilcox, D.A., 2003, Differences in sedge fen vegetation upstream and downstream from a managed impoundment: American Midland Naturalist, v. 150, no. 2, p. 199-220. [Also available at https://www.jstor.org/ stable/3566548.]

Krusi, B.O., and Wein, R.W., 1988, Experimental studies on the resiliency of floating Typha mats in a freshwater marsh: Journal of Ecology, v. 76, no. 1, p. 60-72. [Also available at https://doi.org/10.2307/2260454.]

Leston, L., and Bookhout, T.A., 2015, Yellow rail (Coturnicops noveboracensis): Cornell Lab of Ornithology web page, accessed August 7, 2017, at https://birdsna.org/ Species-Account/bna/species/yelrai.
Littell, R.C., Milliken, G.A., Stroup, W.W., Wolfinger, R.D., and Schabenger, O., 2007, SAS for mixed models (2d ed.): Cary, N.C., SAS Institute, Inc., 828 p.

Little, A.M., Guntenspergen, G.R., and Allen, T.F.H., 2010, Conceptual hierarchical modeling to describe wetland plant community organization: Wetlands, v. 30, no. 1, p. 55-65. [Also available at https://doi.org/10.1007/s13157-009-0010-5.]

Main, M.B., and Barry, M.J., 2002, Influence of season of fire on flowering of wet prairie grasses in south Florida, USA: Wetlands, v. 22, no. 2, p. 430-434. [Also available at https://doi.org/10.1672/0277-5212(2002)022[0430: IOSOFO]2.0.CO;2.]

Mallik, A.U., and Wein, R.W., 1986, Response of a Typha marsh community in draining, flooding, and seasonal burning: Canadian Journal of Botany, v. 64, no. 9, p. 2136-2143. [Also available at https://doi.org/10.1139/b86-282.]

McCune, B., and Mefford, M.J., 2011, PC-ORD-Multivariate analysis of ecological data, ver. 6: Gleneden Beach, Oreg., MjM Software, 36 p.

Michigan State Climatologist's Office, 2012, Climate summaries-Seney NWR: Michigan State University web page, accessed July 2, 2012, at https://climate.geo.msu.edu/index. html.

Middleton, B., 2002, Winter burning and the reduction of Cornus sericea in sedge meadows in southern Wisconsin: Restoration Ecology, v. 10, no. 4, p. 723-730. [Also available at https://doi.org/10.1046/j.1526-100X.2002.01053.x.]

Middleton, B.A., Holsten, B., and van Diggelen, R., 2006, Biodiversity management of fens and fen meadows by grazing, cutting and burning: Applied Vegetation Science, v. 9, no. 2, p. 307-316. [Also available at https://doi.org/10.1111/ j.1654-109X.2006.tb00680.x.]

Milliken, G.A., and Johnson, D.E., 2009, Analysis of messy data, volume 1 -Designed experiments ( $2 \mathrm{~d}$ ed.): Boca Raton, Fla., CRC Press, 674 p.

National Park Service, 2003, Fire monitoring handbook: Boise, Idaho, Fire Management Program Center, National Interagency Fire Center, 274 p.

Neckles, H.A., and Neill, C., 1994, Hydrological control of litter decomposition in seasonally flooded prairie marshes: Hydrobiologia, v. 286, no. 3, p. 155-165. [Also available at https://doi.org/10.1007/BF00006247.]

Nudds, T.D., 1977, Quantifying the vegetative cover of wildlife cover: Wildlife Society Bulletin, v. 5, no. 3, p. 113-117.

Peck, J.E., 2010, Multivariate analysis for community ecologists-Step-by-step using PC-ORD: Gleneden Beach, Oreg., MjM Software, 162 p. 
Pendergrass, K.L., Miller, P.M., and Kauffman, J.B., 1998, Prescribed fire and the response of woody species in Willamette Valley wetland prairies: Restoration Ecology, v. 6, no. 3, p. 303-311. [Also available at https://doi.org/10.1046/ j.1526-100X.1998.06311.x.]

Prince, H., 1997, Wetlands of the American Midwest-A historical geography of changing attitudes: Chicago, Ill., University of Chicago Press, University of Chicago Geography Research Paper No. 241, 399 p.

Reuter, D.D., 1986, Effects of prescribed burning, cutting, and torching on shrubs in a sedge meadow wetland in Symposium of Prescribed Burning in the Midwest - State-of-theArt, Stevens Point, Wisc., March 3-6, 1986, Proceedings: Stevens Point, Wisc., Wisconsin Department of Natural Resources, Fire and Science Center, p. 108-115.

Rooney, S.C., 1990, Fire suppresses woody vegetation in fens (Maine): Restoration Management Notes, v. 8, no. 1, p. 33-58.

Rydin, H., and Jeglum, J.K., 2006, The biology of peatlands: Oxford, U.K., Oxford University Press, 343 p. [Also available at https://doi.org/10.1093/acprof: oso/9780198528722.001.0001.]

SAS Institute, Inc., 2015, SAS/STAT® Software 14.1 user's guide: Cary, N.C., SAS Institute, Inc., accessed January 2017 at http://support.sas.com/documentation/onlinedoc/ stat/141/statug.pdf.

Shay, J.M., Thompson, D.J., and Shay, C.T., 1987, Post-fire performance of Phragmites australis (Car.) Trin. in the Delta Marsh, Manitoba, Canada: Archiv fuer Hydrobiologie Beiheft Ergebnisse der Limnologie, v. 27, p. 95-103.

Slaughter, B., and Cohen, J., 2010, Natural community abstract for patterned fen: Lansing, Mich., Michigan Natural Features Inventory, 273p.

Smith, A.L., 1973, Life cycle of the marsh grass, Scolochloa festucacea: Canadian Journal of Botany, v. 51, no. 9, p. 1661-1668. [Also available at https://doi.org/10.1139/ b73-213.]

Smith, L.M., and Kadlec, J.A., 1985, Comparisons of prescribed burning and cutting of Utah marsh plants: Great Basin Naturalist, v. 45, no. 3, p. 462-466.

Stenzel, J.R, 1982, Ecology of breeding yellow rails at Seney National Wildlife Refuge: Columbus, Ohio, Ohio State University, M.S. thesis, $105 \mathrm{p}$.

Stroup, W.W., 2012, Generalized linear mixed models-Modern concepts, methods, and applications: Boca Raton, Fla., Chapman and Hall/CRC Texts in Statistical Science, 555 p.
Thompson, D.J., and Shay, J.M., 1985, The effects of fire on Phragmites australis in the Delta Marsh, Manitoba: Canadian Journal of Botany, v. 63, no. 10, p. 1864-1869. [Also available at https://doi.org/10.1139/b85-261.]

Thompson, D.J., and Shay, J.M., 1989, First-year response of a Phragmites marsh community to seasonal burning: Canadian Journal of Botany, v. 67, no. 5, p. 1448-1455. [Also available at https://doi.org/10.1139/b89-193.]

Underwood, A.J., 1991, Beyond BACI-Experimental designs for detecting human environmental impacts on temporal variations in natural populations: Australian Journal of Marine and Freshwater Research, v. 42, no. 5, p. 569-587. [Also available at https://doi.org/10.1071/MF9910569.]

U.S. Department of Agriculture, Natural Resources Conservation Service, 2003, The PLANTS Database: U.S. Department of Agriculture, Natural Resources Conservation Service web page, accessed October 24, 2017, at https://plants.sc.egov.usda.gov/java/.

U.S. Fish and Wildlife Service, 2008, Birds of conservation concern 2008. Arlington, Va., U.S. Fish and Wildlife Service, $93 \mathrm{p}$.

U.S. Fish and Wildlife Service, 2009, Seney National Wildlife Refuge Comprehensive Conservation Plan: Minneapolis, Minn., U.S. Fish and Wildlife Service, 198 p., accessed July 2, 2012, at https://www.fws.gov/midwest/planning/ seney/FinalCCP/seney_ccp_textonly.pdf.

van der Toorn, J., and Mook, J.H., 1982, The influence of environmental factors and management on stands of Phragmites australis, I, effects of burning, frost and insect damage on shoot density and shoot size: Journal of Applied Ecology, v. 19, no. 2, p. 477-499. [Also available at https:// doi.org/10.2307/2403481.]

Vogl, R.J., 1969, One hundred and thirty years of plant succession in a southeastern Wisconsin lowland: Ecology, v. 50, no. 2, p. 248-255. [Also available at https://doi.org/10.2307/1934852.]

Ward, E., 1942, Phragmites management: Transactions of the North American Wildlife and Natural Resources Conference, v. 7, p. 294-298.

Warners, D.P., 1997, Plant diversity in sedge meadowsEffects of groundwater and fire: Ann Arbor, Mich., University of Michigan, Ph.D. dissertation, $231 \mathrm{p}$.

Weltzin, J.F., Bridgham, S.D., Pastor, J., Chen, J., and Harth, C., 2003, Potential effects of warming and drying on peatland plant community composition: Global Change Biology, v. 9, no. 2, p.141-151. [Also available at https://doi.org/10.1046/j.1365-2486.2003.00571.x.] 
Wheeler, G.A., Glaser, P.H., Gorham, E., Wetmore, C.M., Bowers, F.D., and Janssens, J.A., 1983, Contributions to the flora of the Red Lake Peatland, northern Minnesota, with special attention to Carex: American Midland Naturalist, v. 110, no. 1, p. 62-96. [Also available at https://doi.org/10.2307/2425214.]

White, K.L., 1965, Shrub-carrs of southeastern Wisconsin: Ecology, v. 46, no. 3, p. 286-304. [Also available at https://doi.org/10.2307/1936332.]

Wilcox, D.A., and Nichols, S.J., 2008, The effects of waterlevel fluctuations on vegetation in a Lake Huron wetland: Wetlands, v. 28, no. 2, p. 487-501. [Also available at https://doi.org/10.1672/07-129.1.]

Young, R.P., 1987, Fire ecology and management in plant communities of Malheur National Wildlife Refuge, southeastern Oregon: Corvallis, Oreg., Oregon State University, Ph.D. dissertation, $183 \mathrm{p}$.

Zhang, Q., Pregitzer, K.S., and Reed, D.D., 2000, Historical changes in the forests of the Luce District of the Upper Peninsula of Michigan: American Midland Naturalist, v. 143, no. 1, p. 94-110. [Also available at https://www.jstor.org/stable/3082987] 


\section{Glossary}

ALDNIC speckled alder, Alnus incana spp. rugosa

ANDGLA bog rosemary, Andromeda polifolia var. glaucophylla

BETPUM bog birch, Betula pumila

CALCANAG bluejoint, Calamagrostis canadensis, and creeping bentgrass, Agrostis stolonifera

CAMAPA marsh bellflower, Campanula aparinoides

CARAQU water sedge, Carex aquatilis, and unknown wide-leaved Carex species

CARBUX Buxbaum's sedge, Carex buxbaumii

CARCHO creeping sedge, Carex chordorrhiza

CAREX narrow-leaved sedges combined (woollyfruit sedge, Carex lasiocarpa; fewseed sedge, C. oligosperma; inland sedge, $C$. interior, and unidentified narrow-leaved Carex species)

CARLIV livid sedge, Carex livida

CHACAL leatherleaf, Chamaedaphne calyculata

ELEELL elliptic spikerush, Eleocharis elliptica

ELEROB Robbins'spikerush, Eleocharis robbinsii

ERIOPH cottongrasses (Eriophorum angustifolium, E. viridicarinatum)

GALIUM bedstraws (northern bog bedstraw, Galium labradoricum; Threepetal bedstraw, G. trifidum)

HYPKAL Kalm's St. Johnswort, Hypericum kalmianum
IRIVER harlequin blueflag, Iris versicolor

LARLAR tamarack, Larix laricina

LYSTER earth loosestrife, Lysimachia terrestris

MC Marsh Creek

MUHGLO spike muhly, Muhlenbergia glom-

erata

POTFRU Shrubby cinquefoil, Potentialla fruticosa

RHYALB white beak-rush, Rhynchospora alba

RUBUS berries (arctic blackberry, Rubus arcticus ssp. acaulis; bristly dewberry, R. hispidus; dwarf red blackberry, $R$. pubescens)

SALIX willows (sageleaf willow, Salix candida, and unidentified Salix species)

SD standard deviation

SOLULI bog goldenrod, Solidago uliginosa

spp. species

ssp. subspecies

SYMBOR Northern bog aster (Symphyotrichum boreale)

SYMPUN Purplestem aster (Symphyotrichum puniceum)

TRIFRA Fraser's marsh St. Johnswort (Triadenum fraseri)

VACCINS Vaccinium species (cranberry, Vaccinium macrocarpon; velvetleaf huckleberry, V. myrtilloides; and unidentified Vaccinium species)

VIOLAS violets (small white violet, Viola macloskeyi; northern bog violet, $V$. nephrophylla) 


\section{Appendix 1. Crosswalk Table of Taxonomy of Plant Species.}

Table 1.1. Crosswalk table of taxonomy of plant species following the Flora of North America (2003) and U.S. Department of Agriculture National PLANTS Database (U.S. Department of Agriculture, Natural Resources Conservation Service, 2003).

[List includes species that may have been found only in blocks C3-7 or C3-8, which were sampled in 2006 and 2007 but not included in analyses. Codes are those used in the field and analyses. Wetness, an indicator of a species' tolerance to wet soils, was from Chadde (2002) to be specific to the study region. Some codes differ from the PLANTS scientific name because the names in the regional guide used (Chadde, 2002) differ from the most recent taxonomy in the PLANTS Database. Wetness, indicator of plant tolerance to wet soils; --, no data; OBL, obligate wetland hydrophyte; FACW, facultative wetland hydrophyte; spp., species; FAC, facultative hydrophyte;(NI), no indicator; **, introduced; UPL, upland nonhydrophyte; ssp., subspecies; var., variety]

\begin{tabular}{|c|c|c|c|c|c|}
\hline \multirow{2}{*}{ Code } & \multicolumn{2}{|c|}{ National PLANTS Database taxonomy } & \multicolumn{2}{|c|}{ Flora of North American taxonomy } & \multirow{2}{*}{ Wetness } \\
\hline & Genus and species & Common name & Genus and species & Common name & \\
\hline \multicolumn{6}{|c|}{ Sedges/rushes/cattail } \\
\hline CAREX2 & Sedge, unknown $2006 \# 2$ & (Probably C. interior) & -- & -- & -- \\
\hline CAREX3 & Sedge, unknown 2007 & -- & -- & -- & -- \\
\hline CAREX4 & Sedge, unknown 2006 \#4 & (Probably C. lasiocarpa) & -- & -- & -- \\
\hline CARAQU & Carex aquatilis & Water sedge & Carex aquatilis & Water sedge & OBL \\
\hline CARBEB & Carex bebbii & Bebb's oval sedge & Carex bebbii & Bebb's oval sedge & FACW+ \\
\hline CARBUX & Carex buxbaumii & Buxbaum's sedge & Carex buxbaumii & Buxbaum's sedge & OBL \\
\hline CARCHO & Carex chordorrhiza & Creeping sedge & Carex chordorrhiza & Cordroot sedge & OBL \\
\hline CAREXI & Carex exilis & Coastal sedge & Carex exilis & Coast sedge & OBL \\
\hline CARLEP & Carex leptalea & Bristlystalked sedge & Carex leptalea & Slender sedge & OBL \\
\hline CARLIV & Carex livida & Livid sedge & Carex livida & Livid sedge & OBL \\
\hline CAROLI & Carex oligosperma & Fewseed sedge & Carex oligosperma & Running bog sedge & OBL \\
\hline CARROS & Carex rostrata & Beaked sedge & Carex rostrata & Beaked sedge & OBL \\
\hline CARUTR & Carex utriculata & Northwest Territory sedge & Carex utriculata & Beaked sedge & OBL \\
\hline DULARU & Dulichium arundinaceum & Three-way sedge & Dulichium arundinaceum & Three-way sedge & OBL \\
\hline ELEELL & Eleocharis elliptica & Elliptic spikerush & Eleocharis elliptica & Elliptic spikerush & FACW \\
\hline ELEROB & Eleocharis robbinsii & Robbin's spikerush & Eleocharis robbinsii & Robbin's spike-rush & OBL \\
\hline ERIANG & Eriophorum angustifolium & Tall cottongrass & Eriophorum angustifolium & Tall cottongrass & OBL \\
\hline \multicolumn{6}{|c|}{ Grasses } \\
\hline GRASS & Grass, unknown spp. & -- & -- & -- & -- \\
\hline AGRHYE & Agrostis hyemalis & Winter bentgrass & Agrostis hyemalis & Ticklegrass & FAC- \\
\hline AGRSTO & Agrostis stolonifera & Redtop & Agrostis gigantea & Redtop & $(\mathrm{NI})$ \\
\hline BROCIL & Bromus ciliatus & Fringed brome & Bromus ciliatus & Fringed brome & FACW \\
\hline CALCAN & Calamagrostis canadensis & Bluejoint, reedgrass & Calamagrostis canadensis & Blue-joint, reedgrass & OBL \\
\hline
\end{tabular}


Table 1.1. Crosswalk table of taxonomy of plant species following the Flora of North America (2003) and U.S. Department of Agriculture National PLANTS Database (U.S. Department of Agriculture, Natural Resources Conservation Service, 2003).- - Continued

[List includes species that may have been found only in blocks C3-7 or C3-8, which were sampled in 2006 and 2007 but not included in analyses. Codes are those used in the field and analyses. Wetness, an indicator of a species' tolerance to wet soils, was from Chadde (2002) to be specific to the study region. Some codes differ from the PLANTS scientific name because the names in the regional guide used (Chadde, 2002) differ from the most recent taxonomy in the PLANTS Database. Wetness, indicator of plant tolerance to wet soils; --, no data; OBL, obligate wetland hydrophyte; FACW, facultative wetland hydrophyte; spp., species; FAC, facultative hydrophyte;(NI), no indicator; **, introduced; UPL, upland nonhydrophyte; ssp., subspecies; var., variety]

\begin{tabular}{|c|c|c|c|c|c|}
\hline \multirow{2}{*}{ Code } & \multicolumn{2}{|c|}{ National PLANTS Database taxonomy } & \multicolumn{2}{|c|}{ Flora of North American taxonomy } & \multirow{2}{*}{ Wetness } \\
\hline & Genus and species & Common name & Genus and species & Common name & \\
\hline \multicolumn{6}{|c|}{ Grasses-Continued } \\
\hline MUHGLO & Muhlenbergia glomerata & Spike muhly & Muhlenbergia glomerata & Marsh muhly & FACW + \\
\hline PANBOR & Dichanthelium boreale & Northern panicgrass & Panicum boreale & Northern panic-grass & -- \\
\hline POASPP & Poa spp. & Bluegrass & Poa spp. & Bluegrass & -- \\
\hline FORB & Forb, unknown spp. & -- & -- & -- & -- \\
\hline ASTNEM & Oclemena nemoralis & Bog aster & Aster nemoralis & Leafy bog-aster & OBL \\
\hline ASTUMB & Doellingeria umbellata & Parasol whitetop & Aster umbellatus & Tall flat-topped white aster & FACW \\
\hline CAMAPA & Campanula aparinoides & Marsh bellflower & Campanula aparinoides & Marsh-bellflower & OBL \\
\hline CHALUT & Chamaelirium luteum & Fairywand & Chamaelirium luteum & Fairywand & FACU \\
\hline CIRMUT & Cirsium muticum & Swamp thistle & Cirsium muticum & Swamp thistle & OBL \\
\hline CIRPAL & Cirsium palustre ${ }^{* *}$ & Marsh thistle & Cirsium palustre ${ }^{* *}$ & Marsh thistle & $(\mathrm{NI})$ \\
\hline COPTRI & Coptis trifolia & Threeleaf goldthread & Coptis trifolia & Threeleaf goldthread & (NI) \\
\hline DROROT & Drosera rotundifolia & Roundleaf sundew & Drosera rotundifolia & Round-leaved sundew & OBL \\
\hline EUPMAC & $\begin{array}{l}\text { Eupatoriadelphus macu- } \\
\quad \text { latus }\end{array}$ & Spotted joe pye weed & Eupatorium maculatum & Spotted joe-pye weed & -- \\
\hline EUPPER & Eupatorium perfoliatum & Common boneset & Eupatorium perfoliatum & Boneset & FACW+ \\
\hline EUTGRA & Euthamia graminifolia & Flat-topped goldenrod & Euthamia graminifolia & $\begin{array}{l}\text { Common flat-topped } \\
\text { goldenrod }\end{array}$ & FACW- \\
\hline GALLAB & Galium labradoricum & Northern bog bedstraw & Galium labradoricum & Labrador bedstraw & OBL \\
\hline LYCUNI & Lycopus uniflorus & Northern bugleweed & Lycopus uniflorus & Northern water-horehound & OBL \\
\hline LYSTER & Lysimachia terrestris & Earth loosestrife & Lysimachia terrestris & Swamp-candles & OBL \\
\hline LYSTHY & Lysimachia thyrsiflora & Tufted loosestrife & Lysimachia thyrsiflora & Swamp loosestrife & OBL \\
\hline MAICAN & Maianthemum canadense & Canada mayflower & Maianthemum canadense & Canada mayflower & $\begin{array}{l}\text { UPL/ } \\
\text { FAC }\end{array}$ \\
\hline MENARV & Mentha arvensis & Wild mint & Mentha arvensis & Field mint & FACW \\
\hline PLAHYP & Platanthera hyperborea & Northern green orchid & Platanthera hyperborea & Northern bog-orchid & FACW+ \\
\hline POTFRU & Dasiphora fruticosa & Shrubby cinquefoil & Potentilla fruticosa & Shrubby-cinquefoil & FACW \\
\hline POTPAL & Comarum palustre & Purple marshlocks & Potentilla palustris & Marsh cinquefoil & OBL \\
\hline RUMORB & Rumex orbiculatus & Greater water dock & Rumex orbiculatus & Great water-dock & OBL \\
\hline SMITRI & Maianthemum trifolium & $\begin{array}{l}\text { Threeleaf false lily-of-the- } \\
\text { valley }\end{array}$ & Smilacina trifolia & False Solomon's seal & -- \\
\hline
\end{tabular}


Table 1.1. Crosswalk table of taxonomy of plant species following the Flora of North America (2003) and U.S. Department of Agriculture National PLANTS Database (U.S. Department of Agriculture, Natural Resources Conservation Service, 2003).—Continued

[List includes species that may have been found only in blocks C3-7 or C3-8, which were sampled in 2006 and 2007 but not included in analyses. Codes are those used in the field and analyses. Wetness, an indicator of a species' tolerance to wet soils, was from Chadde (2002) to be specific to the study region. Some codes differ from the PLANTS scientific name because the names in the regional guide used (Chadde, 2002) differ from the most recent taxonomy in the PLANTS Database. Wetness, indicator of plant tolerance to wet soils; --, no data; OBL, obligate wetland hydrophyte; FACW, facultative wetland hydrophyte; spp., species; FAC, facultative hydrophyte;(NI), no indicator; **, introduced; UPL, upland nonhydrophyte; ssp., subspecies; var., variety]

\begin{tabular}{|c|c|c|c|c|c|}
\hline \multirow{2}{*}{ Code } & \multicolumn{2}{|c|}{ National PLANTS Database taxonomy } & \multicolumn{2}{|c|}{ Flora of North American taxonomy } & \multirow{2}{*}{ Wetness } \\
\hline & Genus and species & Common name & Genus and species & Common name & \\
\hline \multicolumn{6}{|c|}{ Forbs-Continued } \\
\hline SOLGIG & Solidago gigantea & Giant goldenrod & Solidago gigantea & Smooth goldenrod & FACW \\
\hline SOLIDAG & Solidago spp. & Goldenrod spp. & Solidago spp. & Goldenrod spp. & -- \\
\hline SOLULI & Solidago uliginosa & Bog goldenrod & Solidago uliginosa & Northern bog goldenrod & OBL \\
\hline SYMPUN & Symphyotrichum puniceum & Purplestem aster & Aster puniceus & Purple-stem aster & OBL \\
\hline TRIFRA & Triadenum fraseri & $\begin{array}{l}\text { Fraser's marsh St. John- } \\
\quad \text { swort }\end{array}$ & Triadenum fraseri & Marsh St. John's wort & OBL \\
\hline URTDIO & Urtica dioica & Stinging nettle & Urtica dioica & Stinging nettle & $\mathrm{FAC}+$ \\
\hline UTRINT & Utricularia intermedia & Flatleaf bladderwort & Utricularia intermedia & Flatleaf bladderwort & OBL \\
\hline ALDINC & Alnus incana spp. rugosa & Speckled alder & Alnus incana & Speckled alder & OBL \\
\hline ANDGLA & $\begin{array}{l}\text { Andromeda polifolia var. } \\
\text { glaucophylla }\end{array}$ & Bog rosemary & Andromeda glaucophylla & Bog rosemary & OBL \\
\hline AROMEL & Aronia melanocarpa & Black chokecherry & Aronia melanocarpa & Black chokecherry & FACW- \\
\hline BETPAP & Betula papyrifera & White birch & Betula papyrifera & White birch & -- \\
\hline BETPUM & Betula pumila & Bog birch & Betula pumila & Bog birch & OBL \\
\hline CHACAL & Chamaedaphne calyculata & Leatherleaf & Chamaedaphne calyculata & Leatherleaf & OBL \\
\hline ILEVER & Ilex verticillata & Common winterberry & Ilex verticillata & Winterberry, black-alder & FACW+ \\
\hline LARLAR & Larix laricina & Tamarack & Larix laricina & Tamarack & FACW \\
\hline LEDGRO & Ledum groenlandicum & Bog Labrador tea & Ledum groenlandicum & Labrador tea & OBL \\
\hline RUBHIS & Rubus hispidus & Bristly dewberry & Rubus hispidus & Swamp dewberry & FACW \\
\hline RUBPUB & Rubus pubescens & Dwarf red blackberry & Rubus pubescens & Dwarf raspberry & $\mathrm{FACW}+$ \\
\hline RUBUS & Rubus spp. & Raspberry spp. & Rubus spp. & Raspberry spp. & -- \\
\hline SALCAN & Salix candida & Sageleaf willow & Salix candida & Sage-leaf willow & OBL \\
\hline SALIX & Salix spp. & Willow spp. & -- & -- & -- \\
\hline SALPED & Salix pedicellaris & Bog willow & Salix pedicellaris & Bog-willow & OBL \\
\hline SPIALB & Spiraea alba & Meadowsweet & Spiraea alba & Meadowsweet & FACW + \\
\hline SPITOM & Spiraea tomentosa & Steeplebush & Spiraea tomentosa & Steeple-bush & FACW \\
\hline VACCIN & Vaccinium spp. & Vaccinium spp. & Vaccinium spp. & Vaccinium spp. & -- \\
\hline VACMAC & Vaccinium macrocarpon & Cranberry & Vaccinium macrocarpon & Large cranberry & OBL \\
\hline VACMYR & Vaccinium myrtilloides & Velvetleaf huckleberry & Vaccinium myrtilloides & Velvetleaf-blueberry & FACW \\
\hline
\end{tabular}


Table 1.1. Crosswalk table of taxonomy of plant species following the Flora of North America (2003) and U.S. Department of Agriculture National PLANTS Database (U.S. Department of Agriculture, Natural Resources Conservation Service, 2003).- - Continued

[List includes species that may have been found only in blocks C3-7 or C3-8, which were sampled in 2006 and 2007 but not included in analyses. Codes are those used in the field and analyses. Wetness, an indicator of a species' tolerance to wet soils, was from Chadde (2002) to be specific to the study region. Some codes differ from the PLANTS scientific name because the names in the regional guide used (Chadde, 2002) differ from the most recent taxonomy in the PLANTS Database. Wetness, indicator of plant tolerance to wet soils; --, no data; OBL, obligate wetland hydrophyte; FACW, facultative wetland hydrophyte; spp., species; FAC, facultative hydrophyte;(NI), no indicator; **, introduced; UPL, upland nonhydrophyte; ssp., subspecies; var., variety]

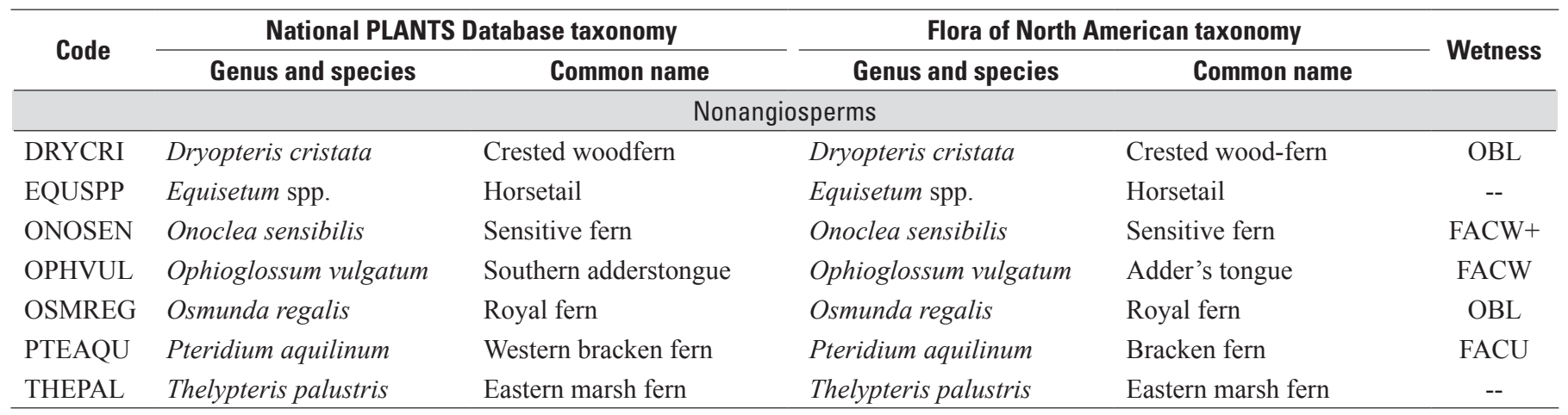

\section{References Cited}

Chadde, S.W., 2002, A Great Lakes wetland flora (2d ed.): Laurium, Mich., PocketFlora Press, 648 p.

Flora of North America Editorial Committee, eds., 2003, Flora of North America North of Mexico, v. 4: New York, Oxford University Press, 512 .

U.S. Department of Agriculture, Natural Resources Conservation Service, 2003, The PLANTS Database: U.S. Department of Agriculture, Natural Resources Conservation Service web page, accessed October 24, 2017, at https://plants.sc.egov.usda.gov/java/. 


\section{Appendix 2. Fire Conditions During Prescribed Burns at Marsh Creek, July 2007 and 2008, and C3, May 2008.}

Table 2.1. Fire conditions during prescribed burns at Marsh Creek, July 2007 and 2008, and C3, May 2008. Data were obtained from Seney National Wildlife Refuge remote area weather station (MesoWest, 2008) and field observations.

[The Keetch-Byram Drought Code is a numerical rating representing the net effect of evapotranspiration and precipitation in producing cumulative moisture deficiency in deep duff and upper soil layers; the index ranges from 0 , the point of no moisture deficiency, to 800 , the maximum drought that is possible. Fuel moisture readings were obtained from the remote area weather station at 13:00 hours. The fire adjective rating is from the Canadian Forest Fire Danger Rating System, as used by Michigan Department of Natural Resources and Seney National Wildlife Refuge (Stocks and others, 1989). Water depth was depth below soil surface to pooled water. ha, hectare; kph, kilometer per hour; cm, centimeter]

\begin{tabular}{|c|c|c|c|}
\hline \multirow[b]{2}{*}{ Burn date } & \multicolumn{2}{|c|}{ Marsh Creek } & \multirow{2}{*}{$\frac{\text { C3 }}{\text { May 9, } 2008}$} \\
\hline & July 17,2007 & July 24,2008 & \\
\hline Burn area (ha) & 21 & 155 & 341 \\
\hline Relative humidity (percent) & $50-30$ & $74-40$ & $70-32$ \\
\hline Air temperature & $24-28$ & $22-28$ & $8-18$ \\
\hline Wind speed (kph) & $6-18$ & $5-13$ & $0-9$ \\
\hline Cloud cover (percent) & $30-60$ & $40-80$ & $80-100$ \\
\hline Keetch-Byram Drought Code & 207 & 116 & 4.5 \\
\hline 1-hour fuel moisture & 5.8 & 8.6 & 7.4 \\
\hline 10-hour fuel moisture & 6.2 & 11.6 & 9.9 \\
\hline 100-hour fuel moisture & 17.8 & 16 & 15.4 \\
\hline Fire adjective rating & $\begin{array}{c}\text { High } \\
\text { (summer criteria) }\end{array}$ & $\begin{array}{c}\text { Moderate } \\
\text { (summer criteria) }\end{array}$ & $\begin{array}{c}\text { Moderate } \\
\text { (spring criteria) }\end{array}$ \\
\hline Water depth (cm) & -12 & $1-7$ & $0-6$ \\
\hline
\end{tabular}

\section{References Cited}

MesoWest, 2008, Great Lakes fire and fuels: MesoWest digital data, accessed July 2008 at https://glff.mesowest.org/.

Stocks, B.J., Lynham, T.J., Lawson, B.D., Alexander, M.E., Wagner, C.V., McAlpine, R.S., Dube, D.E., 1989, Canadian forest fire danger rating system-An overview: The Forestry Chronicle, v. 65, no. 6, p. 450-457. 


\section{Appendix 3. Frequency of Occurrence of Plant Taxa by Block in C3 and Marsh Creek, Seney National Wildlife Refuge, 2006-10.}

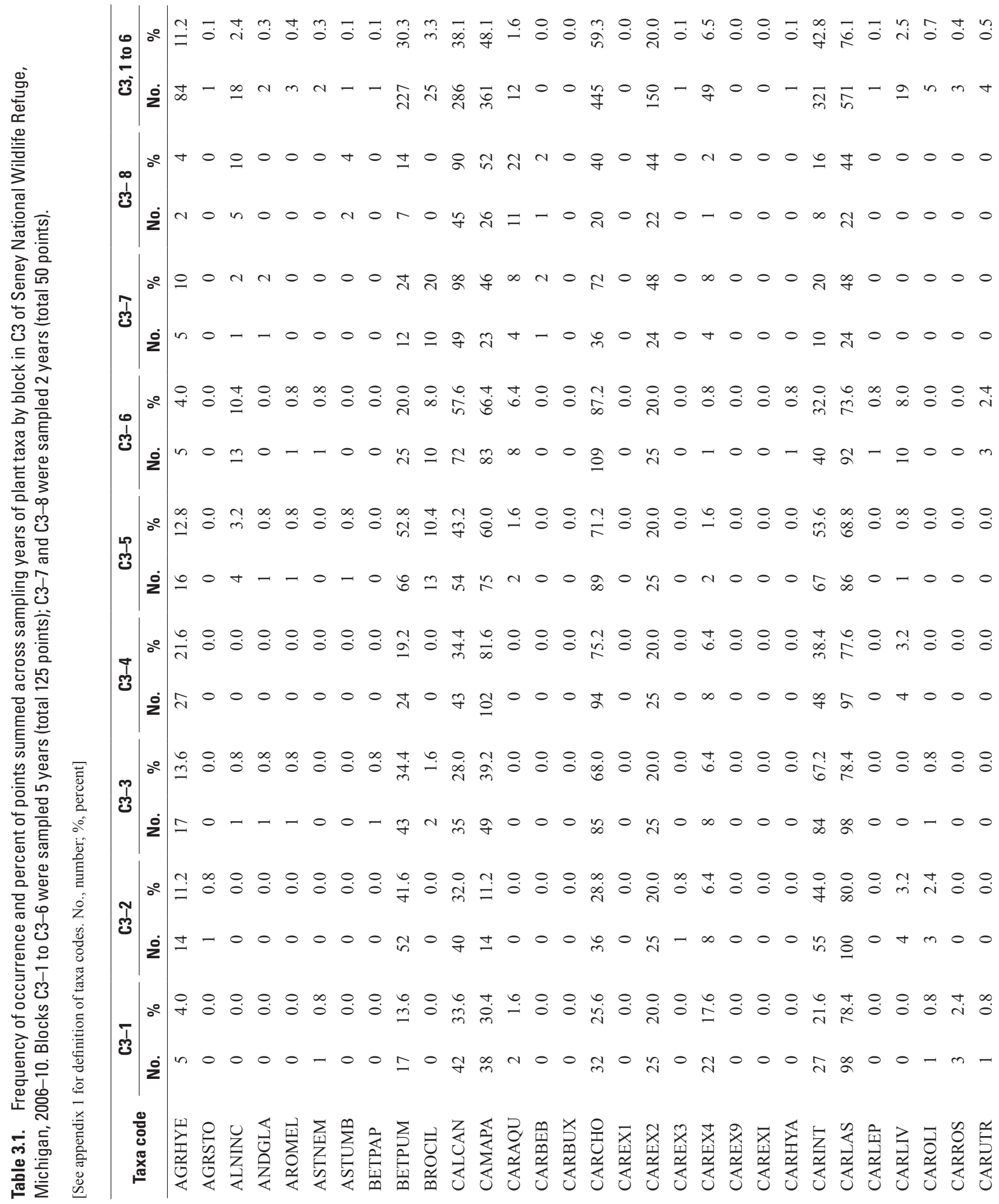




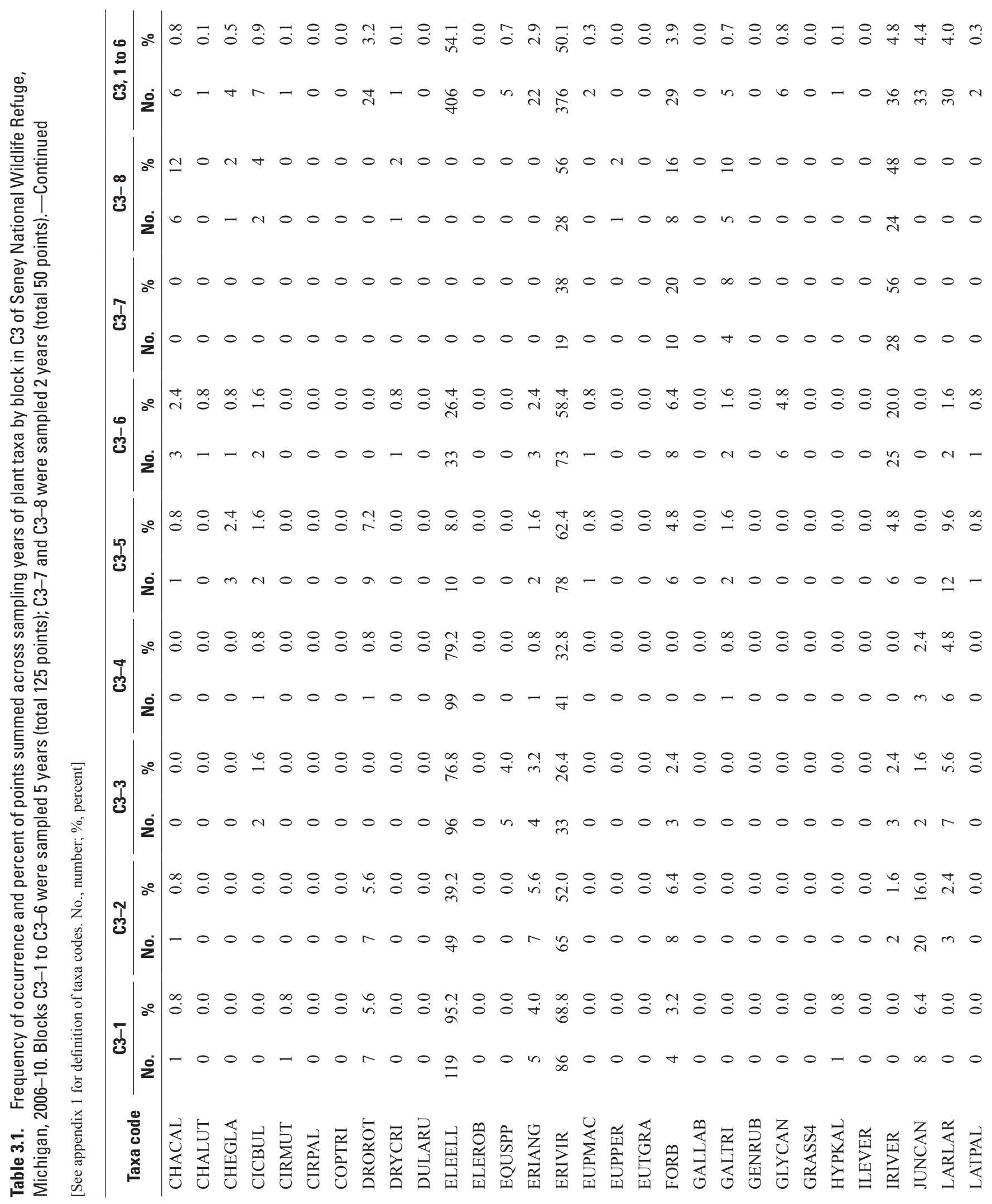




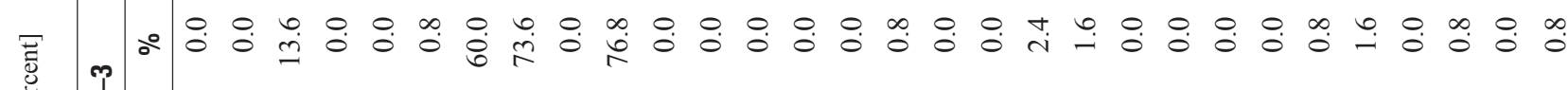
mi

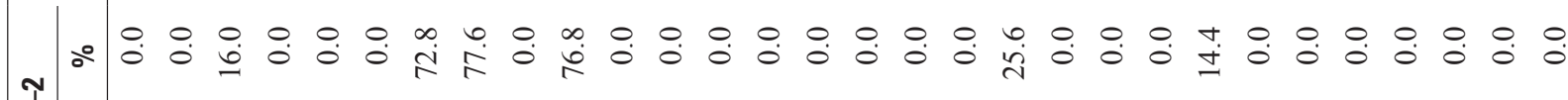
गे गु

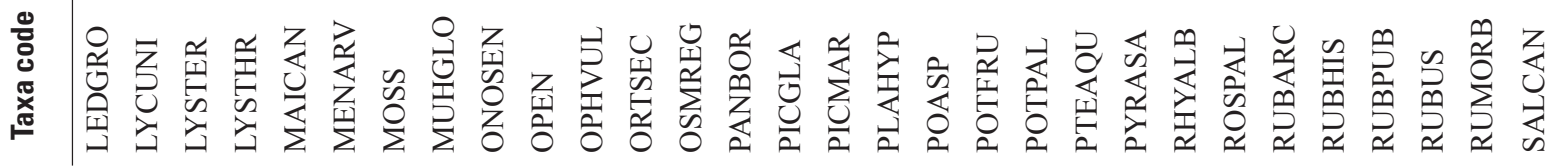




\section{Appendix 4. Frequency of Occurrence and Percent of Points (Summed Across Sampling Years) of Plant Taxa by Block in Marsh Creek, Seney National Wildlife Refuge, Michigan, 2006-10.}

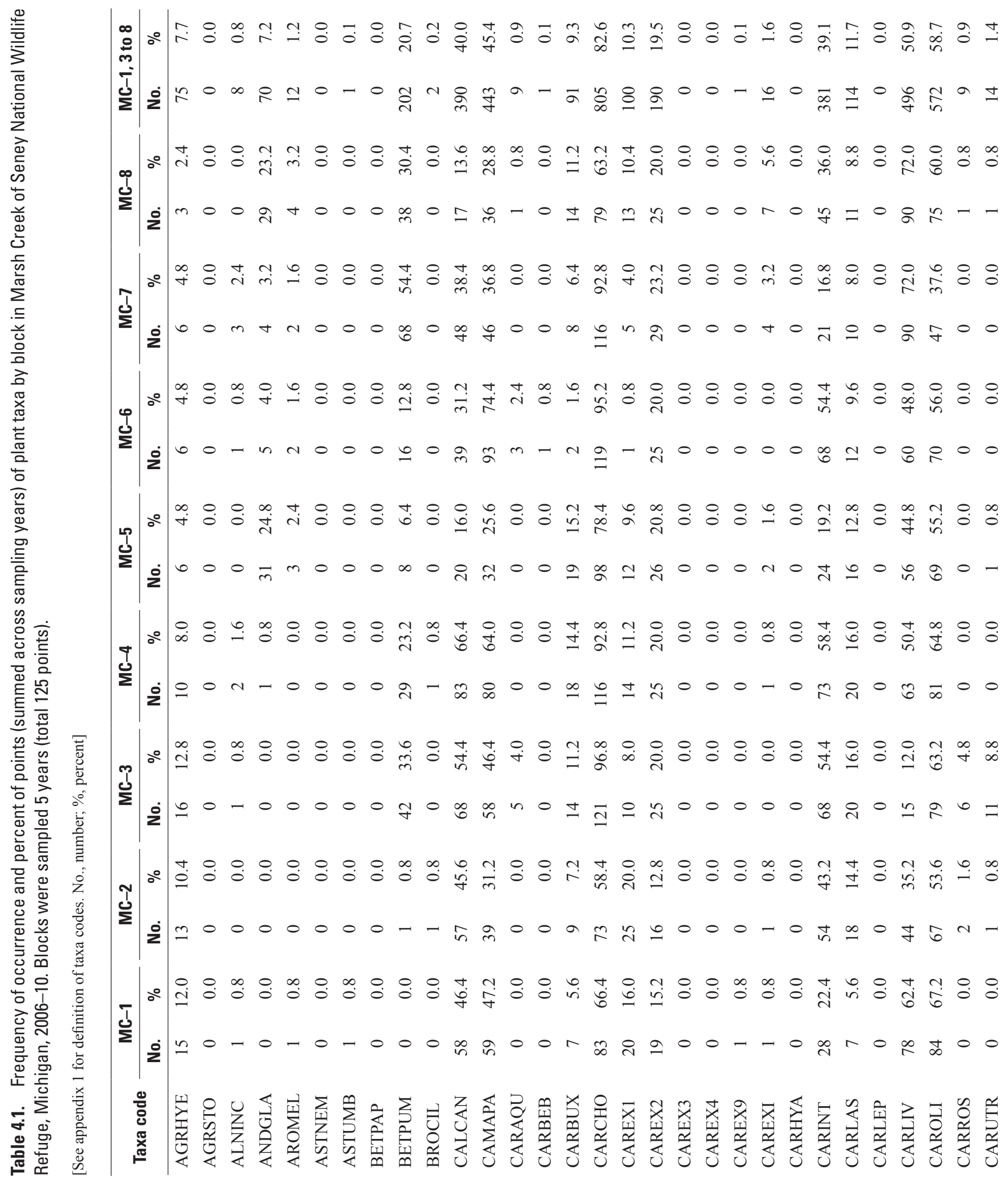




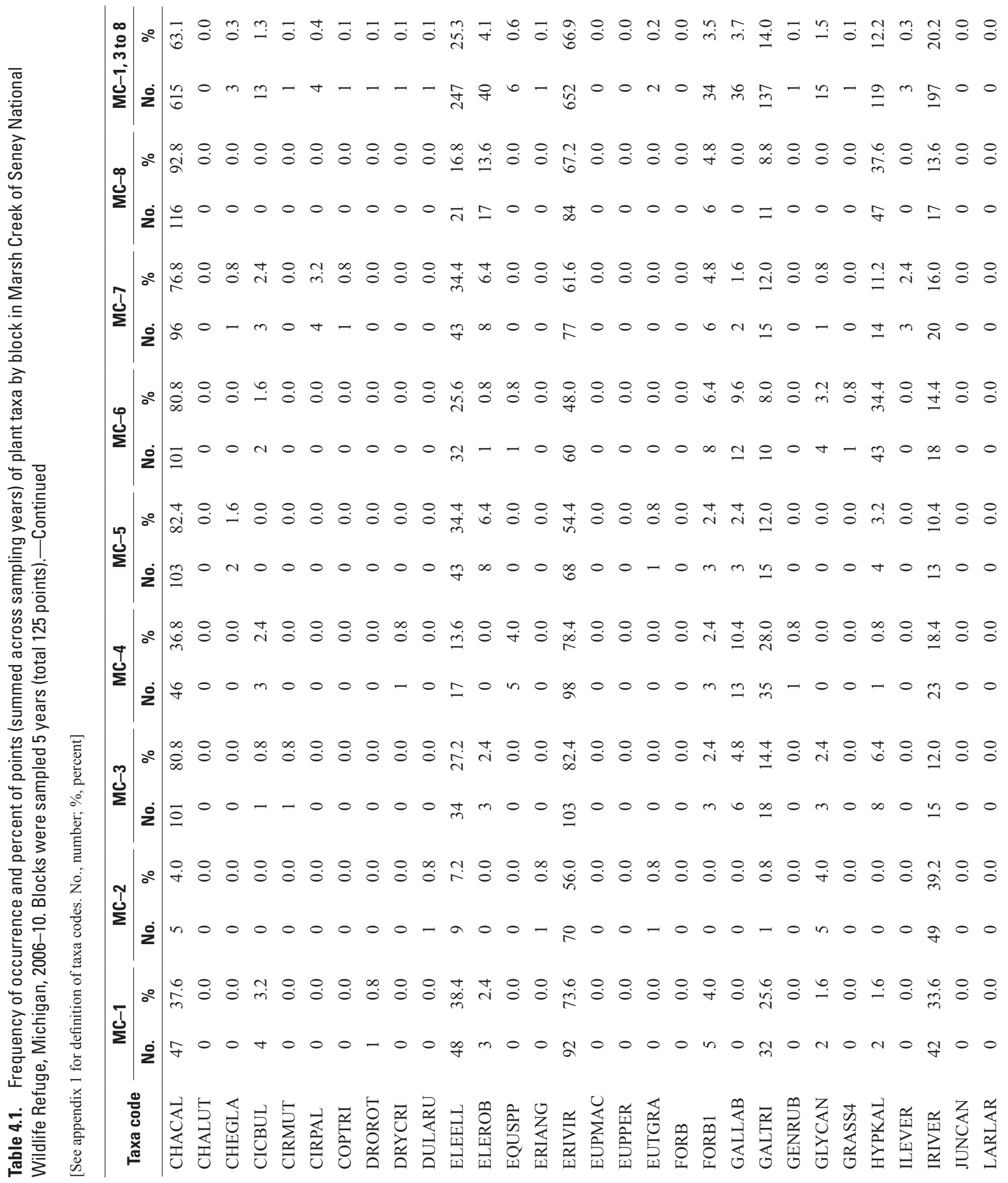




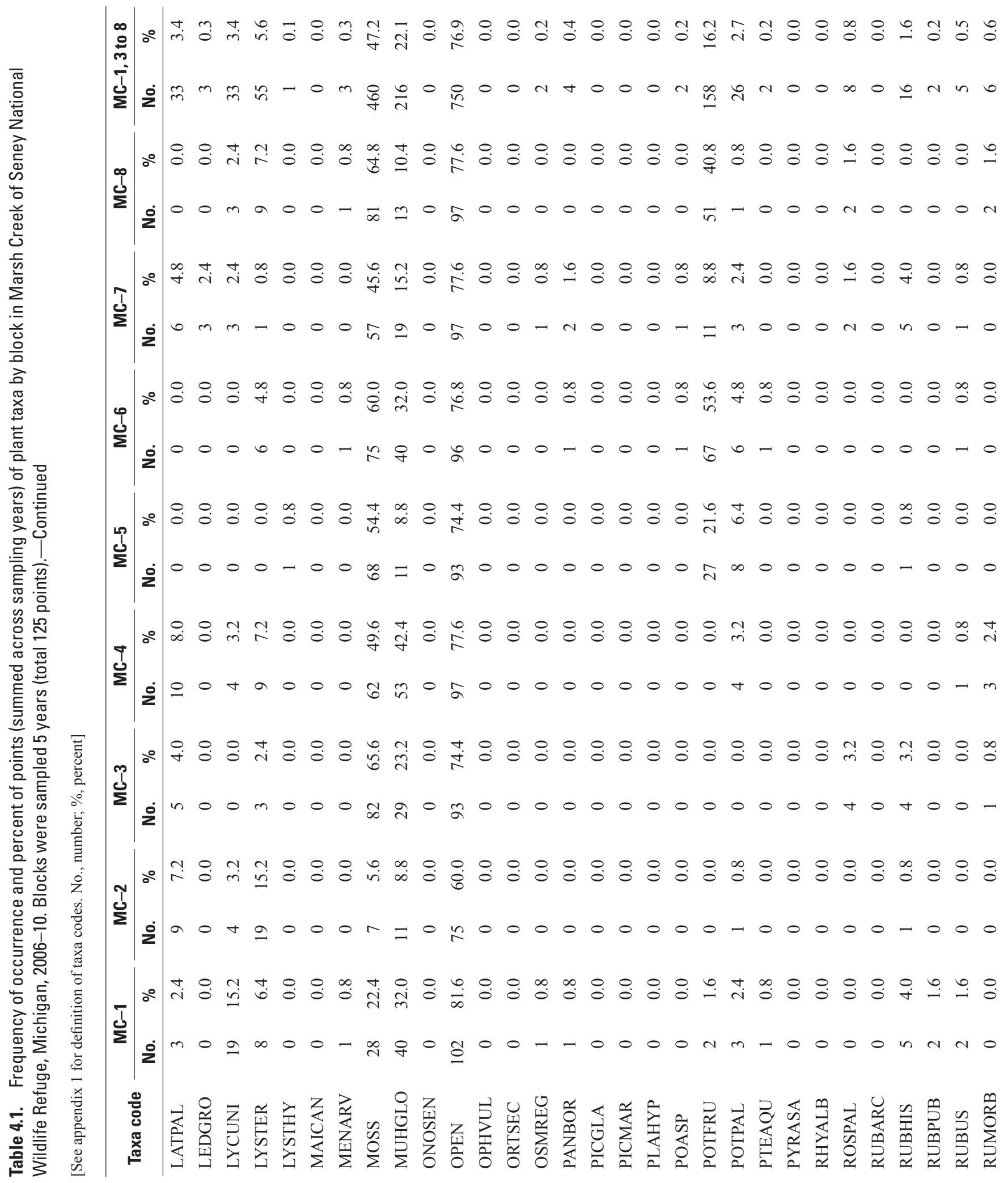




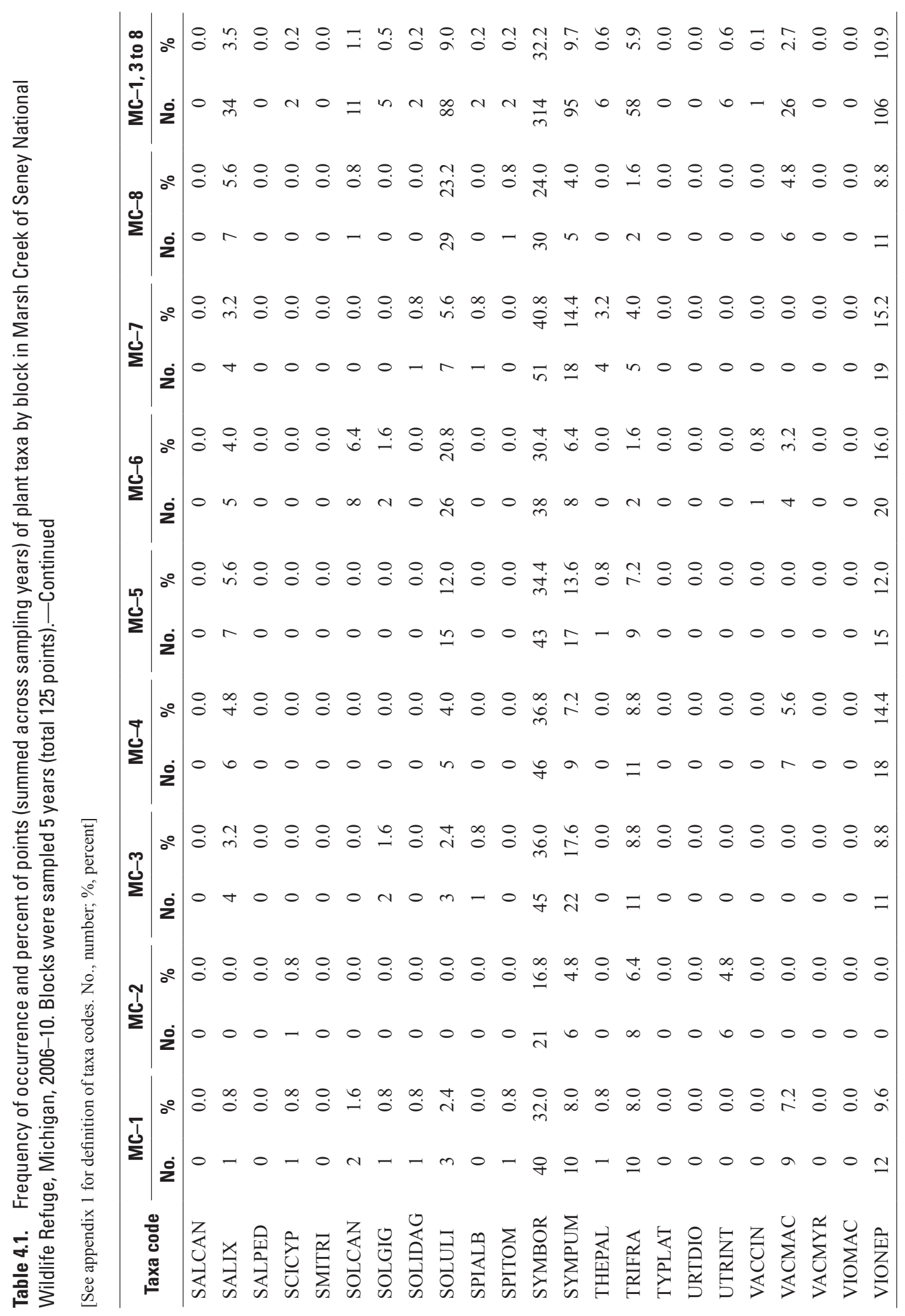


For more information about this publication, contact: Director, USGS Northern Prairie Wildlife Research Center 8711 37th Street Southeast

Jamestown, ND 58401

701-253-5500

For additional information, visit: https://www.usgs.gov/centers/npwrc

Publishing support provided by the

Rolla Publishing Service Center 


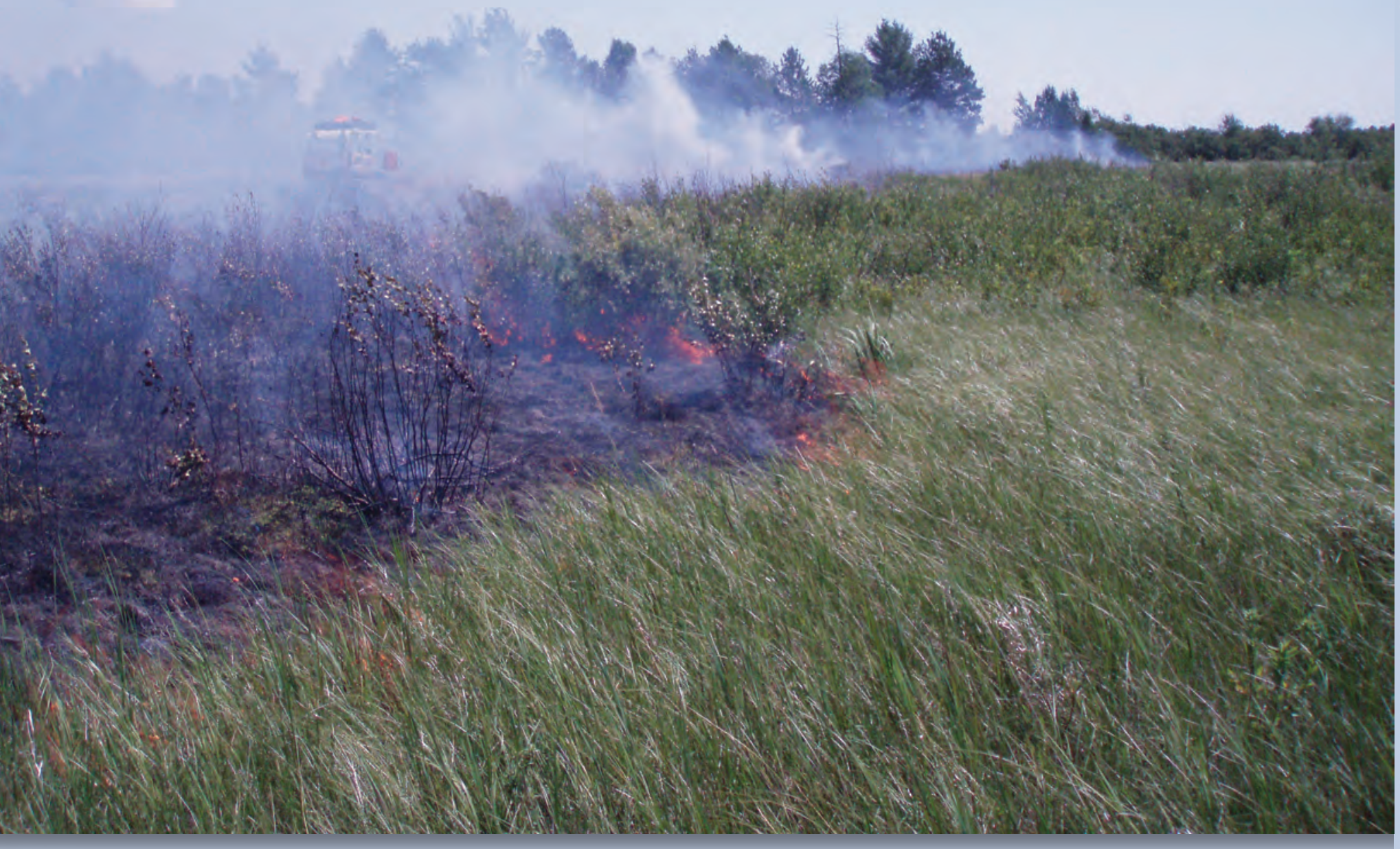

